\title{
Yeniçeri Teşkilatına Dair Bir Risale (Değerlendirme-Karşılaştırmalı Metin)
}

\author{
Ayşe Pul ${ }^{*}$
}

\section{$\ddot{O}_{z}$}

Yeniçeri Ocă̆g'nın tarihini ve kanunlarını incelemek, araştırmak için mümkün mertebe ilk el kaynakların tespit edilip tetkik edilmesi, ocağın tarihî gelişimini ve değişimini takip etmek açısından mühimdir. Bu hususta ulaşılacak her kaynak bu amaç doğrultusunda araştırmacılara 1 şık tutacaktır. Bu eserlerden biri de şimdiye kadar tespit edilememiş olan, TTK (Türk Tarih Kurumu) Kütüphanesi Y/228 katalog numarası ve Avusturya Seferine Dair Bir Risale başlı̆̆ıla kayıtlı olan Yeniçeri teşkilatına dair bir risaledir. Müellif veya müstensihini, yazılış tarihini tam olarak tespit edemediğimiz bu risale, Kanuni Sultan Süleyman'ın Avusturya seferine dair kısa bir giriş ile başlamakta, ordunun içinde bulunduğu durumdan hareketle bir takım ocak kanunları, ocağın bünyesindeki iyileştirme ve tamir gibi imar faaliyetleri, muhtelif merasimler, terfi ve azillere dair anlatılar, kışlaların et ihtiyacı, ihtisap ağalığı vb. gibi hususları küçük ve çarpıcı hikâyelerle örneklendirerek anlatmaktadır.

Risalenin bir nüshası, Süleymaniye Kütüphanesi'nde Esad Efendi No: 3622'de kayıtlı bir mecmua içerisinde yer almaktadır. İkinci nüsha ise, İstanbul Üniversitesi Nadir Eserler Kütüphanesi No: 3293'te kayıtlı bir mecmua içerisinde bulunmaktadır. Bu eser, risalenin bir nüshası olduğu bilinmeksizin çeşitli araştırmalarda kaynak olarak kullanılmıştır. Şimdiye kadar tespit edilemeyen TTK nüshası ise, araştırmacılar tarafindan bilinmediği için herhangi bir çalışmada zikredilmemiştir. Biz bu çalışma vesilesiyle, İstanbul Üniversitesi nüshası ve TTK nüshasını tespit ederek bilim âleminin istifadesine sunduk, hem de mevcut nüshaların metin karşlaş̧ırmasını yaparak, risalede değinilen konuları birinci ve ikinci el kaynaklardan faydalanarak detaylı olarak izah etmeye çalıştık.

Anahtar Kelimeler: Osmanlı, Kanuni Sultan Süleyman, Yeniçeri Ocağı, Risale, Askerî Teşkilat.

* Doç. Dr., Ordu Üniversitesi, Fen-Edebiyat Fakültesi, Tarih Bölümü, Ordu/TÜRKIYE, a.pul69@hotmail.com ORCID: 0000-0003-4322-7072 DOI: 10.37879/belleten.2020.983

Makale Gönderim Tarihi: 15.10.2018 - Makale Kabul Tarihi: 11.08.2020 


\title{
A Pamphlet about Janissary Organization (Critics-Comparative Text)
}

\begin{abstract}
In order to examine and track the development of the history and law of the Janissary Corps, it is important to look at first-hand sources. Every archival source in this regard will shed light on the researchers for this purpose. We ascertained one of these works in the TTK (Turkish Historical Society) Library, which is registered with the catalogue number Y / 228 and titled as Avusturya Seferine Dair Bir Risale. This pamphlet, whose author and date cannot be determined exactly, begins with a brief introduction to Suleiman the magnificent's expedition to Austria, starting from the situation of the army, a number of laws, reconstruction activities such as improvement and repair within the crops, various ceremonies, promotion and dismissals, narratives about the need for meat, barracks, etc. as well as small and striking stories.

A copy of the pamphlet is located in the collection of Esad Efendi nr. 3622, which Fatma Kaytaz evaluated in detail in her article. The second copy is registered in Rare Works Library No: 3293 at the Istanbul University. This copy has been used in various academic works without knowing that it is a copy of the pamphlet. The copy of the TTK was not mentioned in any studies because researchers had not found it until now. With this work, we found the copy of the Istanbul University and the copy of the TTK for the benefit of the academic world, and by making a text comparison of the existing copies, we tried to explain the topics mentioned in the pamphlet in detail by using the first and second hand sources.
\end{abstract}

Keywords: Ottoman, Suleiman the Magnificent, Janissaries, Pamphlet, Military Organization.

\section{Giriş}

Osmanlı teşkilat tarihi içerisinde önemli bir yere sahip olan askerî kurumlarla ilgili çalışmalarda kurumların mahiyetini izah edebilmek için dönem kaynaklarının tespit ve tetkik edilmesi elzemdir. Bu askerî kurumlar içerisinde Yeniçeri Ocağı önemli bir yere sahiptir. Yeniçeri Ocağı'nın kuruluşu hakkında, geçici asker olan yaya müsellemlerin ihtiyacı karşılayamadığı ve disiplinli, düzenli, daimî, maaşlı bir ordunun gerekliliği düşüncesiyle başlangıçta toplanan savaş esirlerinden teşkil edilmiş olduğu görüşü hakimdir. ${ }^{1}$ I. Murad'ın hükümdarlığının ilk yıllarına dayandığı düşünülen ocağın kuruluş tarihi, kesin olmamakla birlikte 1363 yılı olarak

1 Kemal Beydilli, "Yeniçeri", DİA, C 43, İstanbul 2013, s. 450. Ocak hakkında kısa genel bilgi için bk. Ayşe Pul, Yeniçeri Ocağı'nn 68. Ortası Turnacıbaşıllk, Gece Kitaplığı Yay., Ankara 2016, s. 19-59.

Belleten, Aralık 2020, Cilt: 84/Say1: 301; 983-1044 
kabul edilmiştir. ${ }^{2}$ İlerleyen zamanlarda Acemi Ocă̆ı kurulmuş, Devşirme yöntemi ile alınan gençler belli bir süreçten geçerek ocağa dâhil edilmiştir. ${ }^{3}$ Başlarda bin kişiden oluşan ve ocak olarak nitelendirilen teşkilat, zamanla farklı birliklerin dahil edilmesiyle genişlemiştir. ${ }^{4}$ Kanuni Sultan Süleyman zamanında ocağın kanunları son şeklini almış, ancak onun ölümünden 1826 yllında tamamen ortadan kaldırılıncaya kadar devşirme sisteminin bozulması, ocağa kabullerde yapılan usulsüzler, ocak mevcudunun kontrolsüz artması, hazine sıkıntısı, rüşvet, iltimas, özellikle XVI. yüzylın sonlarında yaşanan enflasyonun olumsuz etkileri gibi çeşitli sebeplerle bozulma süreci geçirmiştir. Bu süreçte, XVI. yüzyıl sonları ile XVII. yüzyılda bozuklukların nereden kaynaklandığı ve aranan çareler ile ilgili layihalar ve risaleler kaleme alınmıştır. ${ }^{5}$

Bunların yanı sıra, Yeniçeri Ocă̆ı'nın işleyişinde esas alınan kanunları, teşkilata dair ayrıntılı ve kapsamlı bilgileri ihtiva eden eserleri de tetkik ve tahlil etmek gerekir. Genellikle bugüne kadar aktarılan Yeniçeri usul ve uygulamaları, I. Ahmed dönemi eserlerinden Kavanin-i Yeniçeriyan adlı kaynak eser temel alınarak kaleme alınmıştır. Bu eserin tarihi, dönemin sadrazamı olarak Derviş Mehmed Paşa'dan bahsedilmesinden hareketle 1606 olarak tespit edilmiştir. ${ }^{6}$ Orijinali günümüze ulaşamayan ve farklı kütüphanelerde farklı isimlerle kayıtlı muhtelif

2 Oruç Bey, Osmanh Tarihi (1288-1502) Uç Beyliğinden Dünya Devletine, Sad. Necdet Öztürk, Çamlıca Yay., İstanbul 2009, s. 27. Erdal Küçükyalçın, Turna'nın Kalbi Yeniçeri Yoldaşlığ ve Bektaşilik, Boğaziçi Ün. Yay., İstanbul 2010, s. 26.

3 Ahmed Cevad, Tarih-i Askeri-i Osmani, Mecmua-i Eşkal, Cild-i evvel, İstanbul 1299, s. 46. Asşk Paşaoğlu Tarihi, Haz. Atsız, MEB Yay., İstanbul 1992, s. 51.Gábor Ágoston, Osmanl’da Strateji ve Askerî Güç, Çev. Fatih Çalışır, Timaş Yay., İstanbul 2012, s. 27-28. Küçükyalçın, Turna'nın Kalbi, s. 77.

4 Beyazıt Devlet Kütüphanesi, Veliyüddin Efendi Koleksiyonu, No: 1973'te kayıtlı nüshasının sadeleştirilmesiyle hazırlanan Kavanin-i Yeniçeriyan (Yeniçeri Kanunlar), Yay. Haz. Tayfun Toroser, İş Bankası Yay., İstanbul 2011, s. 57. Bundan sonra kısaca Kavanin-i Yeniçeriyan olarak ifade edilecektir. Mücteba İlgürel, "Yeniçeriler", İA, C 13, MEB Yay., İstanbul 1986, s. 388. İsmail Hakkı Uzunçarşılı, Osmanl Devleti Teşkilatından Kapukulu Ocaklan I, TTK Yay., Ankara 1988, s. 155.

5 Mustafa Akdağ, "Yeniçeri Ocak Nizamının Bozuluşu”, AÜ DTCF Dergisi, C V, Ankara 1947. Dönemin bozulma sebeplerini anlatan siyasetname ve nasihatname türünden eserlerin detaylı değerlendirildiği bir çalışma için bk. Mehmet Öz, Kanun-ı Kadimin Peşinde Osmanlı'da Çözülme ve Gelenekçi Yorumculan, 7. Bsk., Dergâh Yay., İstanbul 2017. Ayrıca bk. Osmanlı Devlet Teşkilatına Dair Kaynaklar Kitâb-ı Müstetâb-Kitâbu Mesâlihi'l-Müslimîn Menâfi'i’l-Mü'minîn-Hırzü'l-mülûk, Haz. Yaşar Yücel, TTK. Yay., Ankara 1988.

6 Eserin yazarı kendisini tecrübeli Yeniçerilerle ayrılmaz bağlantısı olan bir ocak adamı olarak nitelemektedir. Kendisinin Halkulvad seferine katıldığını belirtir. Pál Fodor, "Bir Nasihat-name Olarak Kavânîn-i Yeniçeriyan”, Beşinci Milletlerarası Türkoloji Kongresi, C I, İstanbul 1986, s. 218. Mebde-i Kanun'un sadeleştirilmesiyle hazırlanan bir eser için bk. Orhan Sakin, Yeniçeri Ocağı Tarihi ve Yasalan, Doğu Kütüphanesi Yay., İstanbul 2011. 


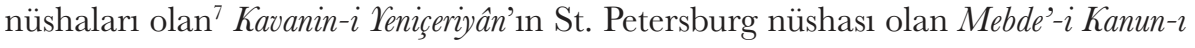
Yeniçeri Ocağı Tarihi adlı eser, Rusça neşrini yapan Petrosyan'a göre, Neşrî gibi klasik Osmanlı Tarihi yazarlarının değerlendirmesine başka ayrıntılar da ekler. Ancak bu ayrıntılar birbiri ile çelişkili olduğundan çok da güvenilir değildir. Kavanin yazarının bilgisi daha sonraki bir döneme aktarılmış sözlü tarih geleneğine dayanmaktadır. Yazar, Yeniçerilerin erken tarihini yazarken XVI. yüzyıl Yeniçerilerinin kendisine anlattıkları ayrıntılardan alıntılar yapıyor gibidir. ${ }^{8}$ Bu kusurlu fakirin dedeleri, Istanbul fatihi Sultan Mehmet Han zamanndan beri, babadan oğula Yeniçeri Ocă̆g hizmetinde olup, yapılan gazalarda can ve baş ile oynadıklarndan başka, bu kullan da ... seferinden beri olan seferlerin çoğunda hazır bulunup ve hala Yeniçeri Ocağı hizmetinde olup, dine ve padişahın devletine dua ve can ve baş ile hizmete devam ederken bir bilge ihtiyar "Ocağın kanun ve kaidelerini dedelerinizden duyduğun ve kendin bilip gördüğün üzere ayrntılarryla padişaha bir risale halinde yazı, beyan et; ta ki bakıldığında kanun ve kaideler gereği gibi uygulanırsa Allah'ın yardımıy la faydası ola" deyince bu biçare de dokuz kısım üzerine beyan ettim diyerek dedesi ve babası gibi ocak mensubu olduğunu ve Sultan I. Ahmed'e sunmak üzere yazdığını ifade eder. Amacının uygulanmayan kanunları hatırlatmak olduğunu vurgular. ${ }^{9}$ Dedesi Saka Mahmud'un 14 yıl İstanbul Ağalı̆̆ı yapmış olduğunu da ifade eder. ${ }^{10}$ Bu eserde müellif, kul sisteminin bel kemiğini teşkil eden Yeniçerilerin kanunlarını, âdetlerini tespit ederek derlemeye çalışmıştır. Sadece ocağın kanunlarını ele almakla kalmamış, ocağın iç mekanizmasını da göstermek istemiştir. Eski ocak geleneklerine aykırı olan uygulamaları ve bunların kaldırılması konusundaki önerileri de ele alarak nasihatname türünden bir eser vücuda getirmiştir. Müellif ocaktaki tecrübeleri doğrultusunda Yeniçerilerin Osmanlı askerî teşkilatındaki önemlerinin bilinciyle, ocak düzelmediği takdirde diğer tüm müesseselerin de düzelmeyeceğini

7 Aşkın Koyuncu, "Kavânîn-i Yeniçeriyân ve Bosnalı Müslüman Çocuklarının Devşirilmesi Meselesinin Tenkidi", Uluslararası Balkan Tarihi ve Kültürü Sempozyumu, 6-8 Ekim 2016, Çanakkale, Bildiriler, C I. Ed. Aşkın Koyuncu, Çanakkale: Çanakkale Onsekiz Mart Üniversitesi Balkan ve Ege Uygulama ve Araştırma Merkezi, 2017, s. 195-196. Kavanin-i Yeniçeriyan'ın dil incelemesi, ses bilgisi ve yapı bilgisi yönlerinden değerlendirildiği bir çalışma için bk. Özgül Özbek, "Yeniçeri Kanunları Kitabı: Kavânîn-i Yeniçeriyân”, Turkish Studies, Volume 13/5, Winter 2018, pp. 375388.

8 Irina Ye. Petrosyan, “Osmanlı Devleti’nin Kuruluşu ve Yeniçerilerin Kökeni”, Türkler, C 10, Yeni Türkiye Yay., s. 134.

9 Kavanin-i Yeniçeriyan, s. 3-4. Ahmet Akgündüz, Osmanh Kanunnâmeleri ve Hukukî Tahlilleri, 9/I. Kitap, I. Ahmed Devri Kanunnâmeleri, 9/II. Kitap, II. Osman Devri Kanunnâmeleri, Osmanlı Araştırmaları Vakfi Yay., İstanbul 1996, s. 127.

10 Kavanin-i Yeniçeriyan, s. 28. 
düşünür. Bu sebeple de Yeniçerilerin gücüne gölge düşüren tüm kanuna aykırı uygulamaların belirlenip kaldırılması fikrini taşır. ${ }^{11}$

Yeniçeri Ocağı ile ilgili diğer önemli kaynaklar ise; Ahmed Cevad'ın Tarih-i Askeri-i Osmani, Eyyubi Efendi Kanunnamesi’nin yanı sıra Kitab-1 Müstetab ve Koçi Bey Risalesi de bozuklukları dile getirirken ocağın eski ve temel kanunları hakkında bilgiler içermektedir. Risaleyi, yukarıda belirttiğimiz eserlerle karşılaştırdığımızda, risalede anlatılan hadiselere, ocağın genişletilmesi ve iyileştirilmesi noktasında imar faaliyetleri ile Kanuni döneminde ihdas edilen bir takım kanunlara dair bilgilere rastlayamadık. Risalenin verdiği bilgilere yakınlığı bağlamında değerlendirirsek Yeniçeri Ocağı tarihini konu edinen eserler içinde, İsmail Hakkı Uzunçarşlı'nın, Kapukulu Ocaklar adlı eserinde, risalede verilen bilgilerle kısmen örtüşen hususlar yer almaktadır. Ancak ele aldığı bazı konuların çalışı̆̆ı̆ıı risalede yer almaması Uzunçarşlı'nın kullandığı kaynağın bu risale olmadığını ortaya koymaktadır. Meselâ Uzunçarşıllı, ocak talimhanesi hakkında bilgi verirken Yeniçeri Teşkilat Mecmuası s. 6-7'den naklen bilgiler vermiş, eserinin farklı sayfalarında ise Yeniçeri Teşrifat Defteri adlı bir çalışmayı daha kaydetmiştir. ${ }^{12}$ Uzunçarşlı'nın bu eserinde zaman zaman Yeniçeri Teşrifat Mecmuası olarak bahsedilen hususi kütüphanesindekinin dışında bir başka eser daha zikredilir. Bu eserin ise Halis Efendi Kitapları No: 6166'da kayıtlı olduğu ifade edilmiştir. ${ }^{13}$ Risalenin farklı nüshaları olma ihtimali kuvvetli olan bu eserlerin orijinal metnine ulaşamadık. Maalesef bunun sebebi, genel olarak eserlerin ya hususî kütüphanelerde yer almaları ya da farklı arşiv ve kütüphanelerde, çoğu kez içeriği yansıtmayan başlıklarla ve nüshalarının farklı adlarla kataloglara kaydedilmiş olmasıdır. Tespit edilebilen nüshalar bazan tamamen tesadüfî olarak karşımıza çıkmaktadır. Keza incelediği-

11 Pál Fodor, "Bir Nasihat-name Olarak Kavânîn-i Yeniçeriyan”, s. 217, 219.

12 Uzunçarşılı, Kapukulu Ocaklan I, s. 333. Ağa Divanı'nda okunan dua metni verilirken Uzunçarşılı bir suretinin Yeniçeri Teşrifat Mecmuası s. 21'de olduğunu ve duaya II. Bayezid'den başlandığını ve arada Yavuz Sultan Selim ve I. Mustafa'nın atlanarak Sultan İbrahim Gazi şeklinde sıralandığını yazıyor. Bahsettiği eserin Avcı Mehmed zamanında yazıldığını ifade ediyor (s. 398). Nadir Eserler Kütüphanesi nüshasında sadece I. Mustafa'nın adı zikredilmemiştir (13b). Teşrifat Mecmuası'nın 7. sayfasında ise Yeniçeri börkü ile ilgili bilgi vardır (s. 267). 12. sayfasında, geçit resimlerinde bayrak taşıma nizamı anlatılmaktadır (s. 291). 14, 15, 17, 19. sayfalarında ocak imamı ile bilgiler bulunmaktadır (s. 233). 17. sayfasında ise yusufi başlık hakkında bilgi vermektedir (s. 272). 22. sayfasında Yeniçerilerin maaş dağıtımı sırasında memnuniyetleri gereği verilen çorbayı içmeleri, buna mukabil kurban kesilmesi ve akide şekeri dağıtımı hususları yer almaktadır (s. 421). 30. sayfada ise, XVII. yüzyılın ilk yarısında göreve gelen Yeniçeri Ağaları ile ilgili bilgi bulunmaktadır.

13 Uzunçarşılı, Kapukulu Ocaklan I, s. 168, 174, 178. 
miz risale de, Avusturya Seferine Dair Bir Risale gibi eserin muhteviyatını tam olarak yansıtmayan bir başlıkla kaydedilmiştir. ${ }^{14}$

Yeniçeri Ocağı kanunları ve işleyişi hakkında yazılmış olan bu risale, kuruluş aşamasından itibaren kaldırıldığı tarih olan 1826'ya kadar hiç kuşkusuz zamanın etkilerine en çok maruz kalan askerî müesseselerden olan Yeniçeri Ocağı tarihi için vazgeçilmez bir kaynak değeri taşımaktadır. Eser, en erken XVII. yüzyıla tarihlendirilen ocak kanunlarını ihtiva eden teşkilat eserlerinde yer alan bilgilerin bir kısmını Kanuni döneminde yaşanmış hadiselere dayandırması, yine bu olaylar çerçevesinde uygulanan kanunları içeren erken tarihli ilk el kaynaklardan olması bakımından bilhassa değerlidir. Daha evvelden Fatma Kaytaz ve Ahmed Akgündüz tarafindan Süleymaniye Esad Efendi nüshasının metin neşri yapılmış, her iki çalışmada da herhangi bir nüshasından söz edilmemiştir. Oysa ki, İstanbul Üniversitesi Nadir Eserler Kütüphanesi No: 3293'te Kanuni Devrinde Yeniçeri Ocaklarna Dair Bazı Merasim başlı̆̆ılla kayıtlı olan bir mecmua içerisinde yer alan ve bu risalenin başka bir nüshası olduğunun farkına varılmaksızın çeşitli araştırmalarda kullanılmış olan ikinci bir nüshası daha bulunmaktadır. ${ }^{15}$ Üçüncü nüshası olan TTK nüshası ise, varlığından dahi bilim dünyasının haberdar olmadı̆̆ı dolayısıyla da hiçbir çalışmada araştırmacılar tarafindan kullanılmamış olan nüshadır. Bu makale vesilesiyle hem İstanbul Üniversitesi Nadir Eserler Kütüphanesi nüshası hem de TTK nüshası bilim dünyasının istifadesine sunulmuştur. ${ }^{16}$ Ayrıca makalede, her üç nüshanın karşılaştırılması yapılarak tenkitli metin neşri yapılmıştır. Metin neşri yapılırken araştırmacılar tarafindan varlığı bilinmediği için kullanılmamış olan TTK nüshası esas alınmıştır. Bunun yanı sıra, risalenin içerdiği Yeniçeri mekanları, tayinatları, talimhane, ocaktan ihraç, ocağa ecnebilerin girişi, tekaüdlük, meratib-i silsile, narh gibi konular, mevcut literatür gözönünde bulundurularak ve devrin diğger kaynaklarındaki bilgilerle karşılaştırılarak ele alınmıştır.

14 Keza İÜ Nadir Eserler Kütüphanesi nüshası farklı bir adla, Süleymaniye Kütüphanesi Esad Efendi nüshası da bambaşka bir başlıkla kataloğa girmişti. Dolayısıyla aynı konuyu çalışanlar için üç farklı eser görünümüne dönüşmüştü. Nüshaların tespiti sürecindeki araştırmamızda Fatma Kaytaz’ın bu husustaki makalesine ulaştık. Fatma Kaytaz, "Osmanlı Askerî Teşkilatı Hakkında Bilinmeyen Bir Eser "Yeniçeri Ocağına Illişkin Bir Risale" (Değerlendirme Ve Metin)", Tarih Dergisi, Sayı 57 (2013 / 1), İstanbul 2013, s. 45-68. Bu çalışmalar hakkında Eserin Nüishalan başlı̆̆1 altında daha ayrıntılı bilgi verilecektir.

15 Bu nüshanın tespitinde, bu makalenin hakemi olan kıymetli hocamızın isabetli ikazları ve yerinde değerlendirmelerinin büyük payı vardır. Önemli katkılarından dolayı kendisine teşekkürü bir borç bilirim.

16 Metnin devamında TTK Nüshası TTKN, Süleymaniye Kütüphanesi Esad Efendi Nüshası SKEEN, IÜ Nadir Eserler Kütüphanesi Nüshası ise IÜNEKN şeklinde kısaltılarak kullanılacaktır. 


\section{A. Eser ve Müellifine Dair}

\section{Eserin Müellifi ve Yazılış Tarihi}

Eserde müellif veya müstensih kendisine dair her hangi bir bilgi vermemektedir. Sonradan eklenmiş bir kayıt da mevcut değildir. Eserde herhangi bir devlet adamına veya büyügüne sunulduğuna dair bir bilgi bulunmamaktadır. Yazarın bir devlet görevlisi olup olmadığı konusu da belli değildir. Anlatımının sadeliğinden ulema sinıfina mensup olmadığı düşünülmektedir. Ancak, dil ve üslûbundan, orta sayıları ve mensuplarına dair ayrıntılı bilgiler vermesinden, ocak teşkilatına vakıf olmasından dolayı ya bizzat ocak mensubu veya görgü şahidi olan bir ocaklıdan duyduğu şeyleri kaleme aldığı anlaşılmaktadır. Bilhassa şahıs isimlerinde yaptı̆̆ı yanlışlardan duyduklarını yazdığı ihtimali güçlenmektedir. Kul Kethüdâsıyla Baş̧̧avuş bi'l-ma'ivye cenk iderlerken Zerrinoğlu ve Bali Beğ oğullarnna rast gelüb 'azîm cenkden sonra ikisin de esîr eyleyüb huzûr-ı padişahîye getürdüler ${ }^{17}$ cümlesi, buna örnek gösterilebilir. ${ }^{18}$

Eserin yazılış tarihi de verilmemiştir. Ancak, Kanuni Sultan Süleyman'dan merhum olarak bahsedilmesi onun hayatta olduğu dönemde yazılmadığını göstermektedir. Ocağın bozulma emarelerinden bahsetmemesi, sadece teşkilattaki bir takım kanunlardan, temel ihtiyaç maddelerindeki fiyat hareketlerinden ve mekânsal geliştirme/iyileştirmelerden bahsetmesi dolayısıyla XVI. yüzyılın sonları veya XVII. yüzyılın başlarında kaleme alındığı fikrini güçlendirmektedir. ${ }^{19}$

\section{Eserin Fizikî ve Şekil Özellikleri}

TTK Yazmalar Kataloğu'nda Y/228 katalog numarasiyla Avusturya Seferine Dair Bir Risale başlığıyla kayıtlıdır. Geniş özet kısmında ise Mensur Kanuni Dönemi Avusturya Seferleri İle Askerin Durumu Hakkında şeklinde ifade olunmaktadır. Yazma eser, vinileks kaplı karton, 237x173 mm ve 178x128 mm ebatındadır. 9 varaktan oluşmakta, $1 \mathrm{~b}$ dışında diğer varaklarda 15 satır bulunmaktadır. Tek sütun halinde olup, siyah haricinde renkli mürekkep kullanılmamıştır. Son derece itinalı bir nesihle

17 Zirinoğluna ve Peykan oğulları (SKEEN 49a); Zirinoğulları ve Palikân oğulları (İ̈NEKN 2b) olarak yazılmıştır.

18 Onaltıncı ve onyedinci yüzyılların büyük kısmında büyük, düzenli, finansmanı merkezden yapılan ordulardan daha ziyade, sınır vilayetlerinin Hırvat-Macar büyük ailelerinden olan Nadasy, Berceny, Batthany ve Zriny gibi ailelerin topladığı ve finanse ettiği küçük ordularıyla karşılaşmışlardı. Bk. Rhoads Murphey, Osmanli'da Ordu ve Savaş 1500-1700, Çev: M. Tanju Akad, Homer Kitabevi, İstanbul 2007, s. 31.

19 TTKN 3a-b. Tarihlendirme meselesi için bk. Kaytaz, "Osmanlı Askerî Teşkilatı Hakkında Bilinmeyen Bir Eser...", s. 49. 
kaleme alınmıştır. Orijinal varak numarası bulunmamaktadır. Sayfa numarası yerine reddade kullanılmış, yani sayfanın ilk kelimesi bir önceki sayfanın alt köşesine yazılmıştır. Bölümlere ayrılmamış, dolayısıyla başlık ya da bölümler arası geçişi sağlayan herhangi bir işaret de yoktur. Metin içerisinde edebî yönü zenginleştirecek şiir, beyt gibi nazım şekillerine de yer verilmemiştir. Altı veya üstü çizili, silinmiş kelimelerin olmayışı müsvedde yazılmadığını göstermektedir. Esere sonradan eklendiği düşünülen der-kenar niteliğinde kayıt bulunmamaktadır. Eserde kurt yeniği vb. gibi olumsuzluklardan kaynaklanan herhangi bir eksik veya silik yoktur.

\section{Eserin Dil ve Üslûbu}

Eser, "Merhum ve mağfur Sultan Süleyman 'aleyhi'r-rahmetü ve'l-gufrân hazretleri Bec kralı” (1b) satırıyla başlamakta, mukaddime bölümü yer almamakta, "ve's-selam tamam oldu" (8b) cümlesiyle son bulmaktadır. Kanuni Sultan Süleyman dönemindeki Beç seferine kısaca değindikten sonra Yeniçeri Ocağı kanunlarına dair hususları özet bir şekilde ele almaktadır. Yazar, bunu "kanun budur ki 'alâ-tariki'l-icmâl beyân olundu" (7b) şeklinde ifade etmektedir. Oldukça sade bir dil kullanılmıştır. Ağır Arapça Farsça terkipler bulunmamaktadır. "Geldik yine Yeniçeri meydanına" (7b) ifadesiyle aslında ele almak istediği temel konunun Yeniçeriler olduğunu vurgulamaktadır. Metnin geneline bakıldığında Yeniçerilerin kahramanlıkları, alçakgönüllülükleri, sadakatlerine vurgu yapılmaktadır. Müellif, Yeniçeri teşkilatına eskiden nasıl olduklarını hatırlatmakta iken, bir taraftan da yöneticilerin cömertlik, mükâfatlandırma gibi uzun zamandır unuttukları âdet ve usulleri açık ve anlaşılır bir Türkçe’yle ifade edilmektedir. Kavanin-i Yeniçeriyan'da bu durum, "ocak işlerini kadim kanuna göre görmek lazımdır ki gittikleri yerde eski sultanlar zamanında yaptıkları gibi erlik ve dilaverlik göstersinler” şeklinde yazılmıştır. ${ }^{20}$

Metinde zaman zaman imla hatalarına rastlanmaktadır. Örneğin, sizlere=sizelere, sancak-1=sancağ̣1, murtaza kelimesi (مرتضى) yerine (مرتضا) şeklinde yazılmıştır (1b-2b). buyurd $1=$ buyurdu, gice $=$ gece $(2 \mathrm{a})$, müjde $=$ mücde $(2 \mathrm{~b}-3 \mathrm{a})$, Dubrovenedik=Dubrevenedik (2b), irtesi=ertesi (3a), irişüb=erişüb (3a), ümîd (اوميد) şeklinde vav ile (3b), cep=çeb (4a), umûr zaman zaman (اومور) ( 4b), aşc1 (عشجى) ( 8a) şeklinde, meşveret kelimesi harekeli olarak (4b), kâgir (كعكير) ( 4b), mum kelimesi ise (مور) şeklinde yazılmıştır (8b). 
Tarafimızdan metnin transkripsiyonu yapılırken mümkün mertebe aslına sadık kalınmaya çalışılmıştır. Örneğin, bozılub=bozulub, olup= olub, ederler= iderler, yerden=yirden, gördü=gördi gibi kelimeler metindeki yazılışlarına göre ifade edilmiştir. Ancak metin içerisinde fark edilmesi gayesiyle şahıs, yer adı gibi özel isimler büyük harfle yazılmıştır. Noktalama işaretleri kullanılmamıştır. Sadece uzatmaları ifade etmek için (^), ayın (') işareti ve hemze için (’) kullanılmıştır. Metin içi konuşma cümleleri tırnak içinde gösterilmiştir.

\section{Eserin Nüshaları}

Yazma eserlerin nüshalarını tespit etmenin en büyük zorluğu, farklı adlarla kütüphane kataloglarında kaydolunmuş olmasıdır. Çoğu kez metnin muhteviyatını bile yansıtmaktan uzak olan bu kayıtlar, araştırmacıların işini bir hayli zorlaştırmaktadır. Biz de, TTK Kütüphanesi'nde yer alan bu eseri önce yeni yazıya aktarıp, hangi konuları ihtiva ettiğini tespit ettikten sonra teşkilat tarihiyle alakalı literatürdeki yerini, bilinirliğini sorguladık. Bu süreçte, eserin bir nüshasının İstanbul Süleymaniye Esad Efendi Kütüphanesi'nde farklı bir başlıkla yer aldığını belirledik. Aynı eser olup olmadığı konusundaki araştırmamızda Fatma Kaytaz’ın bu husustaki makalesine ulaştık. Bu makaledeki bilgilere göre, söz konusu risalenin nüshası, Süleymaniye Kütüphanesi, Esad Efendi nr. 3622'de yer alan bir mecmua içerisindedir. 200 varaktan oluşan bu mecmuada farklı alanlara dair bulunan 15 eserin 3. eseridir. Katalogda "Yeniçeri Ocağına İlişkin Bir Risale" adıyla kayıtlıdır. Metin, mecmuanın 48b-54a yaprakları arasındadır. Keza Fatma Kaytaz’ın bu değerli çalışmasında herhangi bir nüshasından bahsedilmemektedir. Ayrıca bu çalışmada SKEE Nüshası'nın müellif hattı olmadığı, istinsah edilmiş olduğu düşünülmektedir. ${ }^{21}$

Fatma Kaytaz'dan önce bu nüshanın tahlil edilmeksizin metin neşri Ahmed Akgündüz tarafından yapılmıştır. Yeniçeri Teşkilatı İle Alakalı Muhtelif Kanun Hükümleri başlı̆̆ı altında yazar, Kavânin-i Yeniçeriyan dışında bir takım hukukî düzenlemelerin olduğunu ifade ettikten sonra, üç hüküm sıralamış ve ikinci hüküm olarak bu risale hakkında çok kısa bilgi vermiştir. "Kanunî Sultan Süleyman'ın Viyana (Beç) Seferinde ordusunda gördüğ̈̈ mağlubiyet belirtileri üzerine kaleme alınan Yeniçeri Fermâ-

21 Ayrıntılı bilgi için bk. Kaytaz, "Osmanlı Askerî Teşkilatı Hakkında Bilinmeyen Bir Eser...”, s. 4748. Bir başka çalışmada bu nüshadan Ahvâl-i Ocak-ı Yeniçeriyân olarak bahsedilmiştir. Bk. Mehmet Mert Sunar, "XVIII. Yüzyıl ve XIX. Yüzyıl Başları Yeniçeri Kışlaları Üzerine Bir Değerlendirme”, Yeni Bir Askerî Tarih Özlemi Savaş, Teknoloji ve Deneysel Çalş̧malar, Yay. Haz. Kahraman Şakul, Tarih Vakfi Yurt Yay., İstanbul, 2013, s. 266. 
n'dır ve Süleymaniye Kütüphanesi Es'ad Efendi Bölümü No: 3622, vrk. 48/b-54a'da tek nüshası bulunmaktadır. Başka nüshalarm biz elde edemedik" diyerek Esad Efendi nüshası dışında başka nüshasına ulaşmadığının altını çizmiştir. ${ }^{22}$

Risalenin diğer bir nüshası ise, İ̈̈ Nadir Eserler Kütüphanesi No: 3293’te kayıtlı olan bir mecmuanın içerisinde yer almaktadır. IUUNEK nüshası, Talik yazıyla 17 varak, 21 satırdan oluşmaktadır. Ebatı 248x142, 176x73 mm.dir. Kağıdı aharlı, filigranlı; cildi, sırtı bordo bez, üzeri turuncu kağıt kaplıdır. Söz başları kırmızı mürekkepli, serlevhası mihrabiyeli ve müzehheplidir. ${ }^{23}$ Yazarı bilinmeyen bu nüshada en geç tarih olarak 1069/1658-9 yılının zikredilmesi, eserin IV. Mehmed zamanında kaleme alındığını göstermektedir. ${ }^{24}$ Eserin iç kapağında Halis Efendi Kütüphanesi 135 yazmaktadır. 1b-8a aralığında risalenin nüshası yer almakta olup, bu sayfadan itibaren ihtiva ettiği konular kısa başlıklar halinde şu şekilde siralanabilir:

1. Sa'adetlü pâdişâh-1 'alempenah hazretleri veyahûd serdar vezir-i a'zam olub sefere gitdiklerinde büyük alay tertîbi beyân ider (8a). ${ }^{25}$

2. Vezir-i a'zam ile Yeniçeri sefere gitdiklerinde büyük alay (8a) tertîbidir zikr olunur $(8 b-10 b){ }^{26}$

3. Ramazân-1 şerîf-i mübârek ile '1yd-1 şerîf geldikde bayramlaşmak içün vezir-i $a^{6}$ zam ramazan ve bayramlaşma $(10 b-12 a) \cdot{ }^{27}$

4. Der-beyân-1 bayramlaşmak (12a-13b). ${ }^{28}$

5. Haza pâdişâhlara du'a $(13 b-14 a) \cdot{ }^{29}$

6. Defter oldur ki (14a-14b), burada divan olduğunda arz günlerinde akide dağıtı-

22 Akgündüz, Osmanl Kanunnâmeleri ve Hukukî Tahlilleri, 9/I. Kitap, s. 368. Risale metni için bk. Aynı eser, s. 371-377.

23 IÜ Nadir Eserler Kütüphanesi Kataloğu.

24 "defter oldur ki Yeniçeri çayırından ocak ağalarına tevzi" olunan otluklar ki zikr olunur derzamân-ı Ken'an silahdar ağa-yı şehriyârî sene 1069” (IÜNEKN 14b)

25 Teniçeri Teşrifat Mecmuası, s. 11'den naklen Uzunçarşıll, Kapukulu Ocaklar I, s. 627.

26 Teniçeri Teşrifat Mecmuası, s. 11'den naklen Uzunçarşılı, Kapukulu Ocaklan I, s. 628.

27 Yeniçeri Teşrifat Mecmuası, (sayfa numarası verilmemiş) naklen Uzunçarşılı, Kapukulu Ocaklar I, s. 632-634.

28 Teniçeri Teşrifat Mecmuası, (sayfa numarası verilmemiş) naklen Uzunçarşılı, Kapukulu Ocaklar I, s. 634-636.

29 Yeniçeri Teşrifat Mecmuası, s. 21'den naklen Uzunçarşılı, Kapukulu Ocaklan I, s. 398.

Belleten, Aralık 2020, Cilt: 84/Sayı: 301; 983-1044 
mı merasimi anlatılmaktadır, kimlere kaç dirhem verileceği liste halinde verilmiştir. $^{30}$

7. Defter oldur ki (14b) Yeniçeri çayırından ocak ağalarına tevzi‘ olunan otluklar ki zikr olunur der-zamân-ı Ken'an silahdar ağa-yı şehriyârî sene 1069/1658-9. ${ }^{31}$

8. Sa'adetlü ve mehâbetlü pâdişâh-1 'alempenah hazretleri Yeniçeri ocağına rikâb-1 hümâyûn ağalarına beher sene ihsân eyledüği bahariye ve zemistâniye beyan ider el-vâki' sene 1054/1644-45 (15a). ${ }^{32}$

9. Yeniçeri ağası tebdîl oldukda yeni ağaya ocak ağalarının virdiği pişkeşdir ki zikr olunur $(15 \mathrm{a}) .^{33}$

10. Der-beyân-1 ibtidâ ağayân-1 Yeniçeriyân-1 dergâh-1 'âli fî zaman-1 Sultan Selim Han 'aleyhi'r-rahmetü ve'r-rıdvân sene $921 / 1515$ (15b-16a). ${ }^{34}$

11. Tevârîh-i ağa-yı Yeniçeriyân-ı dergâh-1 'âli ibtidâ ağa-yı Yeniçeriyân Ya'kûb ağadır sene 921/1515. Bu tarihten itibaren 1051/1641-42'ye kadar ocak ağaları listesi verilmiştir. $(16 \mathrm{~b}-17 \mathrm{a}){ }^{35}$

Bu noktada şunu da ifade etmek gerekir ki İsmail Hakkı Uzunçarşılı'nın Hususi Kütüphanesi’nde yer alan Yeniçeri Teşrifat Mecmuası da bir diğer nüsha olarak değerlendirilmelidir. Tabiatıyla metin karşılaştırmasına bu nüsha dahil edilememiş, ancak Kapukulu Ocakları adlı eserinde zikredilen kısımlara dipnotlarda ayrıntılı olarak yer verilmiştir.

Her üç nüshada ele alınan konular hemen hemen aynı sıralamayla anlatılmakla birlikte aynı yazarın kaleminden çıkmadığı fikrini güçlendiren farklı ifadeler, eksik veya fazla kelimeler yer almaktadır. SKEEN ve IUUNEKN'de hiç değinilmemiş hususlar olduğu gibi, sadece TTK nüshasında yer alan ifadeler de vardır. Bunlar dipnotlarda açıklanmıştır. Metin neşri yapılırken, SKEEN ve IÜNEKN'de olmayan kelime veya cümleler [ ] içinde, TTK nüshasında yer almayanlar ise italik olarak ifade olunmuştur. Kelime yazılışlarındaki ufak farklılıklar düz, bir veya birkaç cümlelik genel anlatım farklılıkları ise metin içerisinde italik, dipnotta tırnak içerisinde yazılmıştır.

30 Yeniçeri Teşrifat Mecmuası, s. 22'den naklen Uzunçarşılı, Kapukulu Ocaklar I, s. 421.

31 Uzunçarşılı, Kapukulu Ocaklan I, s. 636-637.

32 Teniçeri Teşrifat Mecmuası, s. 24’ten naklen Uzunçarşıll, Kapukulu Ocaklan I, s. 271.

33 Teniçeri Teşrifat Mecmuası, s. 24'den naklen Uzunçarşıll, Kapukulu Ocaklar I, s. 185-186.

34 Teniçeri Teşrifat Mecmuası, s. 25-26'den naklen Uzunçarşılı, Kapukulu Ocaklar I, s. 167-168.

35 Yeniçeri Teşrifat Mecmuası, s. 26'den naklen Uzunçarşılı, Kapukulu Ocaklan I, s. 168. 


\section{B. Eserin Muhteviyatı}

Eser, Kanuni Sultan Süleyman'ın yedinci Avusturya seferinde Yeniçerilerin kahramanlıkları ve İstanbul'a dönüşlerinde padişahın ihsanı olarak kışlalarına su sağlanması; cep akçesi, koyun akçesi, keman akçesi, ihtiyarlara takaütlük ve koruculuk, kışlaların tamiri gibi ihsanlarda bulunulması; ocak kanunları ile ilgili çeşitli uygulamalar, yasak, ceza ve mükâfatlandırma konuları, talimhane yapımı, muhtelif merasimler, terfi ve azillere dair anlatılar, kışlaların et ihtiyacı, ihtisap ağalığına dair konuları ele almaktadır.

Fatma Kaytaz, Kanuni Sultan Süleyman'ın tarihimizde beşinci seferi olarak kabul gören, ancak yazmada sözü edilen yedinci seferin 1533 yllındaki Alaman Seferi olarak bilinen sefer olduğunu, dönemin Yeniçeri Ağası'nın kimliğinden hareketle ortaya koymaya çalışmıştır. ${ }^{36}$ Çünkü altı def'a sefer idüb hikmet-i Hüdâ altı def'ada bozulub yedinci def'ada mükemmel 'asâkir-i muvahhidîn ile tekrâr yine gitdikde ifadesinden bundan önce altı sefer yapılmış, başarıyla sonuçlanmış olsa bile bir süre sonra tekrar sefer yapılmasını gerektiren durumlar oluştuğu, bu yüzden tekrar sefere çıkılacağı ve muvaffak olunacağı anlamı çıarılabilir. Bununla birlikte Ahmed Akgündüz'ün de "Kanunî Sultan Süleyman’n Viyana (Beç) Seferinde ordusunda gördiü̆̈̈ mağlubiyet belirtileri üzerine kaleme ahnan Yeniçeri Fermânn'dır" şeklinde ifadesinden sefer sırasında yaşanılan süreçten bahsedildiği de düşünülebilir ki bu görüşün daha ağırlık kazandığı söylenebilir. ${ }^{37}$

Aslında risalede odaklanılan konunun bu olmadığı, sefer anlatısının sembolik olarak kalmakta olduğu, "Geldik yine Yeniçeri meydanına" (7b) gibi ifadelerle anlaşılmakta, aslında ele almak istediği temel konunun Yeniçeriler olduğu vurgulanmaktadır. Bu vurguyu yaparken, doğruluk kaygısı gütmeksizin duyduklarını kaleme alan yazar için olaylar, yer, şahıs çerçevesinde zaman zaman yanlışa düştügünü görmekteyiz. Zrinyi’nin Zerrinoğlu yazılışı gibi, Ahmed Usta'nın Gedik Ahmed Paşa olarak sanki Kanuni döneminde yaşamış olarak gösterilmesi gibi, yine Ahmed Usta'nın 21. bölüğün aşçısı olmasına rağmen 52. bölüğün aşçısı olarak ifade edilmesi gibi.

Verilen bilgilerin doğruluk/yanlışlık odağının dışında, bir başka açıdan değerlendirildiğinde, sayı sembolleriyle anlatım üslûbu bağlamında yazarın yedi sayısının

36 Kanuni’nin hangi seferi olduğu yönündeki tartışmalar için bk. Kaytaz, "Osmanlı Askerî Teşkilatı Hakkında Bilinmeyen Bir Eser...”, s. 50.

37 Akgündüz, Osmanl Kanunnâmeleri ve Hukukî Tahlilleri, 9/I. Kitap, s. 368. 
sembolize ettiğ $3^{38}$ mükemmellik vurgusunu önplana çıkarmak gibi bir düşüncesi olduğu da göz ardı edilmemelidir. Keza sefer anlatılırken, "Gâzi Hünkâr mahalline vardıkda yedi kırallar ile mukâbil oldukda..." (1b), yedi kıral-ı küffâr (1b), yedi gün yedi gece arâm itmeyüb (2a), yedi 'aded neferen gâziler (3b) gibi ifadeler bu durumu destekler niteliktedir.

Bununla birlikte risale yazarı, padişahın savaş alanında ordunun başında bulunarak askeri cesaretlendirmesi ve gayrete getirmesi, hatta kılık değiştirerek Solakbaşlara rağmen savaşın içine cesaretle girmesinden hareketle sanki eskiye özlemin bir göstergesi gibi II. Selim'den itibaren ordunun başında sefere gitmeyen sultanlara atıfta bulunmak ister gibidir. Bunun yanı sıra askerlerin kahramanlıklarına da vurgu yapmaktadır. ${ }^{39}$

Aşağıda eserin ihtiva ettiği bir takım hususlar alt başlıklar halinde değerlendirilmiştir.

\section{Yeniçeri Mekânları}

Yeniçeri Ocağı'nın yaşamsal, askerî, dinî bütün faaliyet alanlarını kapsayan ve sağlayan mekân Yeniçeri kışlalarıydı. İstanbul'un fethi öncesinde kışla olarak da adlandırılan ${ }^{40}$ Yeniçeri Ocağı, önceleri Edirne'deyken İstanbul'un fethinden sonra merkezi İstanbul olmuştur. ${ }^{41}$ Acemioğlanlar ve Yeniçerilerin kışlaları ${ }^{42}$ şimdiki Şehzadebaşı denilen yerde yaptırılmıştır. Yangın vs. sebeplerle bir süre sonra Fatih Sultan Mehmed zamanında Yeni odalar ${ }^{43}$ denilen başka bir mekân oluşturulmuş $^{44}$, zamanla Tekkeler Meydanı, Et Meydanı ve Orta Camii ile birlikte büyük

38 Annemarie Schimmel, Saynlarn Gizemi, Çev. Mustafa Küpüşoğlu, Kabalcı yay., İstanbul 2000, s. 24. Yedi sayısı için bk. $140 \mathrm{vd}$.

39 TTKN 2a-3a. Selânikî Mustafa Efendi, Tarih-i Selânikî (971-1003/1563-1595), C I-II, Haz. Mehmet İpşirli, TTK Yay., Ankara 1999, s. 482, 783. 23 Muharrem 1004 (28 Eylül 1595)'de padişahın genç ve sağlıklı olduğunu, neden kendileriyle sefere çıkmadığını söylemekteydiler. s. 524.

40 Beydilli, "Yeniçeri”, DİA, s. 457. Yüksel Çelik, "II. Mahmud Devrinde İdari-Askeri Bir Üs: Rami Kışlası", Osmanl Araştırmalan / The Journal of Ottoman Studies, LII, 2018, s. 229-231.

41 İsmail Hakkı Uzunçarşılı, Osmanı Tarihi, C II, TTK Yay., Ankara 1983, s. 556. Necdet Sakaoğlu, "Eski Odalar", Dünden Bugüne Ístanbul Ansiklopedisi, C III, s. 203-204.

42 A. Süheyl Ünver, "Yeniçeri Kışlaları", Belleten, C XL, S. 160, Ankara 1976, s. 590. Godfrey Goodwin, Yeniçeriler, Çev. Derin Türkömer, Doğan Egmont Yay., İstanbul 2008, s. 39, 73.

43 Bir başka görüşe göre ise, Yeni Odalar Kanuni zamanında yapılmıştı. Bk. Necdet Sakaoğlu, "Yeni Odalar", Dünden Bugüne İstanbul Ansiklopedisi, C VII, s. 467.

44 Kavanin-i Yeniçeriyan, s. 151. Mehmet İpşirli, "Osmanlı Devlet Teşkilatına Dair Bir Eser: Kavânîn-i Osmânî ve Râbita-i Âsitâne”, I. İ. Edebiyat Fakültesi, Tarih Enstitüsü Dergisi, XIV, 1994, s. 26. Sakin, 
bir kompleks haline gelmiştir. İstanbul'un fethinden sonra dahi bilhassa Kanuni döneminde Avrupa seferlerinin sıklı̆̆ından dolayı, Edirne'deki kışlalar aktif kullanılmış, bu sebeple zaman zaman tamirat ve bakımdan geçirilmişlerdir. ${ }^{45}$

Fatih döneminde inşa edilen kışlaların zamanla ihtiyacı karşlayamadı̆̆ görülmekte, mevcutları tadilat ve tamirattan geçirme zorunluluğu doğmaktaydı. Bilhassa su konusunda yetersizlikler görülmüş, II. Bayezid zamanında yeni su yolları eklenmiş, Kanuni döneminde ise Kırkçeşme suyolunun inşası ve genişletilmesinden sonra problem halledilmişti. ${ }^{46} \mathrm{Bu}$ minvalde risalede odaların tamir edilmesinin yanı sıra kışlada odaların önüne kadar su getirilmesinin hikâyesine yer verilmişti. Buna göre, Kanuni Sultan Süleyman seferden zaferle dönen komutanlara hilat giydirdikten sonra mükâfat olarak bir kese altın ihsan etmişse de onlar odalarına su getirilmesi ricasında bulunmuşlardı. Padişah İstanbul'a dönüldükten sonra kışlalarına su getirilmesi için hatt-1 hümayun vermişti. ${ }^{47}$ Kanuni, kışlaları ziyaret ettiği bir gün askere sudan memnun olup olmadıklarını sormuş, onlar getirilen suyun ancak havuzları doldurmaya yettiğini, dolayısıyla faydalanamadıklarını söyleyince odaların önüne kadar suyun getirilmesi emrini vermiş̧i. Yigirminci cemâ'atin evvelinden on bu bölï̆̈̆in dört bölïğün kışlasma kadar akan bu suların toplandığ havuzların iyi kullanılması, boşa harcanmaması konusunda da uyarısını yapmıştı. ${ }^{48}$ Kırk çeşme suyollarının inşasında çalışan Acemi oğlanları hizmetleri bitince kapıya çıkarılmışlardı. 1 Muharrem 968/22 Eylül 1560 tarihli Yeniçeri Ağası'na yollanan emirde isimleri deftere yazılan 23 oğlanın kapıya çıkarılması istenmişti. ${ }^{49}$ Yine bu zamanda odaların tamiri gündeme gelmiş, odalarn kârizlerin ka'gîr yapdırp ve merâmâtı lâzım minîden virilmek üzere Şehremîni üzerine mesârifâttm ta'yîn buyurmuştu. ${ }^{50}$ Odaların tamiri sırasında Makbul İbrahim Paşa, ortaya bir cami yapılmasını padişaha arz etmiş, odaların kapılarını sağlam yapıp içeriye kadın, şarap ve yasak olan şeylerin girmesini, ayrıca vakitsiz içeriye kimsenin girmesi önlemek istemiştir. 13. Yayabaşıların odası kaldırılarak yerine Orta Mescid yapılmışıı. Tamirden

Yeniçeri Ocağr, s. 33-36, 293. Mehmet Mert Sunar, "İstanbul'da Yeniçeri Mekânları: Eski ve Yeni Odalar”, Antikçağdan XXI. Yüzyzla Büyük İstanbul Tarihi, C II, İstanbul, 2015, s. 191.

45 Sakin, Yeniçeri Ocağı, s. 34-35. Sunar, "Yeniçeri Kışlaları Üzerine Bir Değerlendirme”, s. 253-254.

46 Sunar, "Yeniçeri Kışlaları Üzerine Bir Değerlendirme", s. 265-266.

47 TTKN 3b-4a.

48 TTKN 5b.

49 Ahmed Refik, "Devşirme Usulü, Acemi Oğlanlar", Dârülfuinûn Edebiyat Fakültesi Mecmuası, C V, S. 1-2, Haziran 1926, İstanbul Milli Matbaa, 1927, s. 7.

50 TTKN 4b.

Belleten, Aralık 2020, Cilt: 84/Sayı: 301; 983-1044 
sonra odaları gezerken Orta Mescid'de öğle namazını kılmış, imam ve müezzinine Şehremini'nden ulufe tayin etmiştir. Bu mescid III. Murad zamanında Yeniçeri Ağası olan Mehmed Ağa tarafindan genişletilip cami haline getirilmiştir. ${ }^{51}$ Mescid inşası konusu risalede, "ba'dehu aşcllar namaz kılmak içün bir mescid binâ idüb ve bir masura su ve bir musluk ve bir dehlîz binâ idüb "kullarn ta'yinât bir yerde gerekdir" deyû bir de mahzen binâ idïb" şeklinde ifade edilirken bunun yanı sıra diğer imar faaliyetlerinden bahsedilmiștir. ${ }^{52}$

Yeni Odalar'ın önündeki Et Meydanı olarak anılan meydan aynı zamanda Yeniçeri Meydanı olarak da zikredilmekteydi. Kışlaların önemli bir parçasıydı. ${ }^{53}$

Yine risalede Yeni Odalar'dan bahisle her bir kapıya kapıcı tayin edilmesi konusu işlenirken SKEEN'de ve İÜNEKN'de yedi kapıya kapıcı tayin edilmesi şeklinde daha açık şekilde vurgulanmışt. ${ }^{54}$ Keza Yeni Odalar'da dışa açılan yedi adet giriş kapısı vardı. Bunlar 56. Cemaat kapısı (Solaklar Kapıs1), 73. Cemaat kapısı (Karaköy Kapısı), 13. Cemaat kapısı (Âdet Kapısı), 70. Cemaat kapısı (Meydan Kapısı), 2. Ağa bölüğ̈ kapısı, 52. Cemaat kapısı, 57. Cemaat kapısı idi. ${ }^{55}$

\section{Talimhane}

Yeniçeri Ocağı klasik dönemde düzenli talim yapmakta olan bir kurumdu ve bu talimlere tüm ocak mensupları katılmak durumundaydı. Yeniçeriler hafta üç gün ok ve tüfek atış talimleri yaparlardı. Ok talimlerini Talimhanecibaşı, tüfek talimlerini ise Avcıbaşı denilen zabitler yaptırırlardı. Büyük zabitler de 3-4 ayda bir talimhanede nezaret ederlerdi. ${ }^{56}$ Padişah ise senede bir defa Okmeydanı'ndaki talimlere katılırdı. Merasimle Ocak zabitanı nişangâha rütbelerine göre tüfek atışı yaparlardi..$^{57}$

Talimhanecibaşı 54. Bölüğün çorbacısı idi. Bu ve bölük halkı ok atan yoldaşlara ve kemankeşlere ok verir, talim ettirir ve padişah sefere gitmedikçe Talimhaneci

51 Kavanin-i Yeniçeriyan, s. 152-153.

52 TTKN 7b-8a.

53 TTKN $7 b$.

54 TTKN 4b, SKEEN 50b, İ̈̈NEKN 4a.

55 Kavanin-i Yeniçeriyan, s. 153. Sunar, "Yeniçeri Kışlaları Üzerine Bir Değerlendirme”, s. 257.

56 Uzunçarşılı, Osmanl Tarihi II, s. 557. Sakin, Yeniçeri Ocağı, s. 296.

57 Uzunçarşılı, Kapukulu Ocaklar I, s. 333. Pul, Turnacıbaşılık, s. 80. 1015/1606 yılında Ok meydanındaki talim yapma merasimi için bk. Topçular Kâtibi Abdülkadir, Kadrî Efendi Tarihi, C I, Haz. Ziya Yilmazer, TTK Yay., Ankara 2003, s. 480. 
de gitmezdi. Talimhanecinin başında yusufi başlık ile her gün gelip Solaklara ve kemankeşlere talim ettirmesi kanundu. Ocak talimhanesinde Kanuni Sultan Süleyman kendisine bir yer ve çeşme yaptırmıştı. Padişah senede bir buraya gelir atış talimlerinde bulunur başarılı olanların kimine dülbend ve kimine kemân ve kimine çıkn ile akşe ihsân ederdi. Padişahın gelişinde Seksoncular da hazır bulunur seksonla$\mathrm{rI}^{58}$ ayılara saldırtıp parçalattırırlar, ${ }^{59}$ ve pehlivanlar güreş tutarlardı. Her Yeniçeri odasında birer ikişer pehlivan bulunması kanundu. Gürz sallamak ve atma yarışmaları yapılırdı. Solak ve kemankeşler de maharetlerini gösterirlerdi. ${ }^{60}$ Ocağın Talimhane ve Okmeydanı denilen atış meydanlarında mükemmel hedefleri vardı. Burayı II. Bayezid'in yaptırmış, Kanuni zamanında ise genişletilmişti. Kanuni tarafindan At Meydanı'nda bir talimhane yapılmış, hedef olarak belirlenen yerlere yonma taştan kargir bir duvar, bunun orta yerinde somaki mermerden nişangâhlar konulmuştu. Bundan başka meteris için somaki miller diktirilmişti. ${ }^{61}$

Ok meydanında padişah geldiğinde Yeniçeri Ağası başta olmak üzere ocak zabitleri nişangâha tüfek atarlardı. Önce Yeniçeri Ağası yer öper, ağa tüfenkçileri tüfengi doldurup ona verirlerdi. Sonra Sekbanbaşı, Kul Kethüdası, Zağarcıbaşı, Seksoncubaşı, Turnacıbaşı, dört Haseki, Başçavuş sırayla atış yaparlardı. Sonra Başçavuş evvela cemaat sonra bölük çorbacılarına attırırdı. ${ }^{62}$ En son seğirdim aşçıları gelip yarış halinde et kaparlardı ve en başarılısına Solaklık ihsan edilirdi. ${ }^{63}$

\section{Ocak Tayinatı}

Yeniçeri kanununa göre, kapıya çlkan Yeniçeriler üç ayda bir ulufe almaktaydılar. ${ }^{64}$ Başlangıçta kıdemlerine göre iki ilâ beş akçe arasında yevmiye tayin olu-

58 Et Meydanı içerisinde sekson adı verilen köpeklerin barınması için seksonhane bulunmaktaydı. Bunlara bakmakla yükümlü olan birim 71. Cemaat ortasıydı. Bk. Sunar, "Yeniçeri Kışlaları Üzerine Bir Değerlendirme”, s. 267.

59 TTKN (6a) ve IUUNEKN'de (6a) Seksoncu başı seksonlan bir bir indirüb derken SKEEN'de samsoncıbaşı ayuy samsonlara pârelendir[ür] di (52a) ifadesi yer almaktadır.

60 TTKN 6a-b. Uzunçarşılı, Kapukulu Ocaklan I, s. 332. Uzunçarşılı bu bilgileri Yeniçeri Teşkilat Mecmuası s. 6, 7'den nakletmiştir. 271. sayfadaki bilgiler için de yine Hususi Kütüphanesi'nde bulunan bu mecmuayı kullanmıştır. “... bütün gün başinda yusufi ile durub tüfenk atanlara ve Solaklara ve sâ'ir kemankeşlere ta 'lim itmeğe me'mûrdur" İ̈UNEKN 5a.

61 TTKN 6a. Yeniçeri Teşrifat Defteri s. 6'dan naklen Uzunçarşll, Kapukulu Ocaklan I, s. 229.

62 TTKN 6b. Yeniçeri Teşkilat Mecmuası s. 6,7'den naklen Uzunçarşıll, Kapukulu Ocaklan I, s. 333. Sakin, Yeniçeri Ocağı, s. 347.

63 TTKN 6b.

64 Kavanin-i Yeniçeriyan, s. 84. Beydilli, "Yeniçeri", DİA, s. 454. Mehmet Mert Sunar, "Ulufe", DIA, C 
nan Yeniçerilere Kanuni Sultan Süleyman zamanında günlük beş-altı akçe ulufe ödenmekteydi. ${ }^{65}$ Genel anlamda sekiz akçeden fazla ulufe alamazlardı. İş göremez duruma gelip oturak yani emekli olduklarında beş akçesini hazineye devrederler, üç akçe almaya devam ederlerdi ${ }^{66}$ Kavanin-i Yeniçeriyan'da ayrıca sefere gitmeyenlerin yerinin oturaklık olduğu, ulufelerini eskiden beri camilerin fazlalıklarından aldığı, bu durum zorlaştğ̆ında II. Selim zamanından itibaren üçer akçe maaşla birlikte çuhalarının da Yeniçerilerle birlikte verilmesinin kanun olduğu belirtilmekteydi. Bunlar, otuzar akçelik yay akçesini alamamaktaydılar. ${ }^{67}$

Ayrıca tahta cülusta bahşiş ve terakki ${ }^{68}$ verilmesi de âdettendi. Bunlara ilave olarak Yeniçeriler padişahların ilk seferlerinde de bahşiş alırlardı. Kıdem ve hizmetlerine göre tımar sahibi de olabilmekteydiler. ${ }^{69} \mathrm{Bu}$ tür uygulamalar, sefer sırasında askerin motivasyonunu yükseltmek için teşvik primi mahiyetindeydi. 1529 Viyana kuşatmasında Kanuni Sultan Süleyman taarruzdan önce düşman savunma hatlarını yaracak ilk askere çeşitli vaatlerde bulunmuştu. Bu bir tımarlı olacaksa subaşlığa terfi ettirilmesi, zaten subaşıysa sancak beyliği verilmesini emretmişti. Bir gönüllü veya dirlik sahibi değilse bu asker, 30 bin akçeli tımarlılar arasına katılacaktı. ${ }^{70}$ Yeniçeri odalarına her ulufede terakki denilen ve hak sahiplerine dağıtılması gereken bir miktar akçe daha vardı. Birkaç çeşidi olan bu terakkilerden biri de mukarrer adı altında verilmekteydi. Bu miktar, her üç ayda bir ulufede bütün ocağa aralarında dağıtılmak üzere toplam 300 akçeydi. ${ }^{71}$ Risalede bu ödeneğe dair herhangi bir bilgi yoktur.

Görevlerinin (inzibat, muhafizlık, sefarethane güvenliği, yangın söndürme, dip-

42, İstanbul 2012, s. 124-126.

65 Gyula Káldy-Nagy, "The First Centuries of The Ottoman Military Organization", Acta Orientalia, Tomus. XXXI, Budapest 1977, s. 168.

66 Kavanin-i Yeniçeriyan, s. 68, 88.

67 Kavanin-i Yeniçeriyan, s. 80, 90.

68 Terakkilü denilen ulufelerine 3-5 akçe eklenmiş olan Yeniçerilerin kalelerde görevlendirilmesi ve bu usulün de bozulması hakkında bk. Mustafa Nuri Paşa, Netayicü'l-Vukuat, C I-II, Sad. Neşet Çağatay, TTK Yay., Ankara 1992, s. 298.

69 İlgürel, "Yeniçeriler", İA, s. 389. Coşkun Üçok- Ahmet Mumcu, Türk Hukuk Tarihi, Savaş Yay., Ankara 1991, s. 202.

70 Murphey, Osmanli'da Ordu ve Savaş, s. 50.

71 İrina Ye. Petrosyan, Mebde'-i Kanûn-ı Yeniçeri Ocağı Tarihi, Moskova 1987, s. 97 (46a). Ayrıca bk. Kavanin-i Yeniçeriyan, s. 69. Uzunçarşılı, Kapukulu Ocaklan I, s. 425, 427, 455. Ömer Işbilir, XVII. Yüzynl Başlarnnda Şark Seferlerinin İâşe, İkmâl ve Lojistik Meseleleri, İ.Ü. Sosyal Bilimler Enstitüsü, Basılmamış Doktora Tezi, İstanbul 1996, s. 154. 
lomatik koruma vb.) mahiyetlerine ${ }^{72}$ göre her türlü maddi destek de kendilerine sağlanmaktaydı. Bu destekler gıda maddesinden muhtelif ihtiyaç malzemelerine, konaklamadan güvenliğe, ulaşımdan yolluğa pekçok kalemden oluşmaktaydı. Ek gelir olarak adlandırabileceğimiz bu tayinat içerisinde cep akçesi, koyun akçesi, yaka akçesi, keman akçesi, barut akçesi, nafaka gibi nakdî ödemelerin yanı sıra buğday, et, un, ekmek, peksimet, bal, pirinç, yağ, mum gibi temel ihtiyaç maddeleri de bulunmaktaydı. Zaman zaman serdarlar da sefer sırasında emrinde görevli Yeniçerilere bir takım ihsanlar da bulunmaktaydılar. Örneğin Nasuh Paşa İran savaşları sırasında ocağa Kurban akçesi adında bir mikdar meblağ ihsan etmişti. ${ }^{73}$ Risalede, "Gâzi Hünkâr Eski Saraya binis idüb Altı böliüğun Sipahiler ağalarnna ve Kethüdâlarna ve Yeniçeri Ocağl halkına ve Yeniçeri kullarna 'azîm ziyâfetler eyleyüb ve çeb akçesi yă̆mur misâli yağdırub ve çil para ile kanşdırub tepsiyle kullarnna bezl idüb Yeniçeri Ağasına ve Kul Kethüdâsma ve Baş̧̧avus ăgaya ve sâ'ir ocak ağalarna hil'at-i fâhire giydirüb ve ba'dehu senede yüz elli kise akçe koyun akçesi ve üç ayda bir kerre her bir nefere kirkar akçe yaka akçesi ve barut

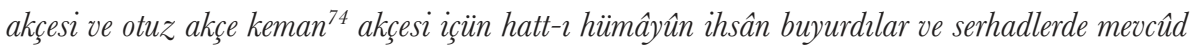
neferâta yamakana yevmiye ikişer akçe nafaka ve ayda birer kile halburlanmış buğday ve iki ademe bir vukyyye lahm... "955 şeklinde Yeniçerilere verilen nakdî ve aynî ödeneklerden bahsedilmekteydi. Bu ifadeler bize Kanuni zamanında Yeniçeri’ye yapılan ihsanların nasıl cömertçe yapıldığını, ileriki zamanlarda yılda bir defa verilen bu ödeneklerin bu dönemde üç ayda bir olmak üzere yılda dört defa yapıldığını göstermektedir. IÜNEKN'de de Yeniçeri ocağ̊ halkına muhabbet eyleyüb böylesine çok ihsanlarda bulunan padişahın cömertliği dile getirilmekteydi. ${ }^{76}$

Âdet-i nân-horân adı altında, Yeniçerilerin yetimlerine fodla verilmekteydi. Bunlar I. Ahmed zamanında 1655 kişiydi. Her nefere üç ayda un akçesi diye 15'er

72 Ayrıntılı bilgi için bk. İlgürel, "Yeniçeriler", IA, s. 388-389. Uzunçarşılı, Osmanh Tarihi II, s. 557. Goodwin, Yeniçeriler, s. 100-101. Üçok- Mumcu, Türk Hukuk Tarihi, s. 204. Howard A. Reed, "Ottoman Reform and Janissaries: The Eşkenci Lâyihas of 1826”, Türkiye'nin Sosyal ve Ekonomik Tarihi (1071-1920), Ed. Osman Okyar-Halil İnalcık, Ankara 1980, s. 194.

73 Kadri Efendi Tarihi, I, s. 572.

74 "Kanun-1 keman-baha, ki yılda her bir nefere otuzar akçe senede bir Şevval, Zilkade ve Zilhicce mevacibine -ki ana kitab istılahınca lezez mevacibi ttlak olunur. Keman-baha deyu mevacibleri ile maan verilmek kanun-1 kadimdir". Bk. Hezarfen Hüseyin Efendi, Telhisï’l-beyân fi Kavânîn-i Âl-i Osmân, Haz. Sevim İlgürel, TTK Yay., Ankara 1998, s. 150. Eyyubî Efendi Kânûnnâmesi Tahlil ve Metin, Yay. Haz. Abdülkadir Özcan, Eren Yay., İstanbul 1994, s. 46. Akgündüz, Osmanh Kanunnâmeleri ve Hukukî Tahlilleri, 9/I. Kitap, s. 92.

75 TTKN 4a.

76 IÜNEKN 7a-b.

Belleten, Aralık 2020, Cilt: 84/Sayı: 301; 983-1044 
akçe verilmekteydi. Hizmette olan Acemi oğlanlarına ise ayda 5'er akçe olmak üzere üç ayda bir ulufeleriyle birlikte âdet-i zerpul denilen bir ödeme yapılmaktayd. Kanuni zamanında Haseki Sultan Camii inşasında çalışan Acemilere de ayda beş akçe pabuç akçesi verilmesi ferman olunmuştu. ${ }^{77}$

Tayinat içinde yiyecek malzemeleri olduğu kadar giyecek de önemli bir yer tutmaktaydı. Bunların giyecek ihtiyaçları da devlet tarafindan karşılanmaktaydı. Fatih Kanunnamesi'nde Yeniçeri taifesine ylllık 5'er zira lacivert çuka ve II. Murad zamanında yılda bir defa on bir akçe olan yaka akçesinin 32 akçeye çıkarılması, başlarına sarmak için 6'şar zira astar verilmesi hükmü konmuştu. ${ }^{78}$ Görüldüğü gibi Kanuni zamanında yaka akçesi yılda dört defa olmak üzere 40 akçeye yükseltilmişti.

Her Çarşamba ocağa 15 bin mum, Yeniçeri çavuşları başlarına selimî sarıkları giyerek 16 dirhem üzerinden yllda 70 bin mum dağıtılırdı. ${ }^{79}$ Yeniçerilere üçü bir akçeden mum satılırdı. Fiyat artışı durumunda aradaki farktan doğan zararı, zarar-1 lahm gibi devlet karşılardı. Ayrıca ocağa ait 75 mum imalathanesi vardı. Etmeydanı'nın mumcu dükkanları da meşhurdu. ${ }^{80}$

Kanuni zamanından beri sınır kalelerindeki Yeniçeriler, maaşlarından başka nafaka akçesi adıyla birer akçe -ki Risale'de ikişer akçe-, ayda bir kile kalburlanmış buğday ve günlük iki muhafız için bir okka et alırlardı. ${ }^{81}$ Yine Kanuni tarafindan mum, bal, pirinç, revgan virilmek için kışlada “kullarn ta'yinât bir yerde gerekdir" denilerek bir mahzen bina edilmişti. ${ }^{82}$

\section{Et ve Et Meydanı}

Yeniçeri Ocă̆ı'nın bir kısım temel ihtiyaç maddeleri devlet tarafindan karşılanmaktaydı. Bunların başında küşt, lahm denilen et gelmekteydi. Genel itibarıyla

77 Akgündüz, Osmanh Kanunnâmeleri ve Hukukî Tahlilleri, 9/I. Kitap, s. 92. Ahmed Refik, "Devşirme Usulü, Acemi Oğlanlar”, s. 7.

78 Fatih Sultan Mehmed, Kanunname-i Al-i Osman (Tahlil-Karşzlaştırmah Metin), Haz. Abdülkadir Özcan, Kitabevi, İstanbul 2003, s. 14. Kaytaz, "Osmanlı Askerî Teşkilatı Hakkında Bilinmeyen Bir Eser...”, s. 52. Yusuf Halaçoğlu, XIV ve XVII. Yüzynllarda Osmanhlarda Devlet Teşkilatı ve Sosyal Yapr, TTK Yay., Ankara 1995, s. 51

79 Kavanin-i Yeniçeriyan, s. 96.

80 TTKN 8b. Özcan, "Etmeydanı”, DİA, s. 497. Uzunçarşıll, Kapukulu Ocaklan I, s. 206.

81 Teniçeri Teşrifat Mecmuası s. 4’ten naklen Uzunçarşıll, Kapukulu Ocaklan I, s. 325.

82 TTKN 7b-8a. 
Yeniçeri Ocağı bünyesinde odalara koyun eti verilmesi kanundu. ${ }^{83}$ Bu kanun çerçevesinde, ocağa etin getirilmesi ve dağıtımı sırasında yapılan uygulamalar sultan ve kapıkulları arasında nimete hizmet bağlamında bir mukavele anlamı da taşımaktayd1. ${ }^{84}$

Ocağın et ihtiyacı, İstanbul mezbahalarından karşılanırdı. Fakat zaman zaman görülen et sıkıntısı ve fiyat artışları sebebiyle Fatih Sultan Mehmed döneminden itibaren Yedikule Mezbahası'nda kesilen hayvanların etlerinin tamamı da buraya tahsis edilmişti. Fatih zamanında, etin fiyatı ne olursa olsun Yeniçerilere 3 akçeye verilmesi kabul edilmiş, fiyat farkından doğan zararı karşılamak için belli bir meblağ para vakfedilmişti. ${ }^{85}$ Cepheye hareket etmeden önce Yeniçerilere hazırlıklarını tamamladıkları süreçte kendilerine verilen çeşitli ödeneklerin yanı sıra zarar-ı nân ve zarar-1 lahm gibi temel ihtiyaç maddelerini satın alabilmeleri için maddi desteğin sağlandığı vakf-ı nukud adı altında, 1474-1477 yılları arasında Veziriazam olan Gedik Ahmed Paşa tarafindan onun yirmibirinci alaydaki aşçıbaşılık tecrübesine dayanılarak bir fon oluşturulmuştu. Paşa, sadece askerlere mahsus kasaplar ve un pazarı (Unkapanı) açılmasını da sağlayarak tedarikte sıkıntı çekmelerini önlemek istemiştir. ${ }^{86}$

Kanuni devrinin başlarında ise, Fatih Sultan Mehmed tarafindan yaptırılan Yeni Odaları Veziriazam İbrahim Paşa yeniden tanzim ettirirken selhanelerden getirilen etleri ayrı bir kapıdan içeriye aldırarak meydanlık yerde dağıttırmış, daha sonra bu kapıya Et Kapısı denildiği gibi meydana da Et Meydanı adı verilmiş, sonraları kapı da Et Meydanı Kapısı adıyla anılmaya başlanmıştır. ${ }^{87}$ Kışlanın önemli bölümlerinden olan Et Meydanı, Yeni Odaların önünde bulunan ve her gün et ihtiyacının miri fiyattan karşılandığı yerdi. ${ }^{88}$ Et Meydanı'na açılan kapı, Meydan Kapısı olarak da adlandırılan 70. Cemaat kapısıydı. Bu kapının yanında küçük bir

83 Mebde-i Kanun, s. 140 (67b). Ayrıca bk. Kavanin-i Yeniçeriyan, s. 94. Genellikle her bir Yeniçeri'ye genel olarak 60 dirhem yani 200 gr. et verilmekteydi. Merkezden uzakta olan ocak mensuplarına da muayyen miktarda et tahsis edilmekteydi. Örneğin 1611 yllında merkezden Van muhafazası için gönderilen Yeniçerilerin günlük et tahsisatı 160 gr.dı. (İşbilir, XVII. Yüzynl Başlarnda Şark Seferlerinin İasse, İkmâl ve Lojistik Meseleleri, s. 45).

84 Cemal Kafadar, "Yeniçeriler", Dünden Bugüne İstanbul Ansiklopedisi, C 7, Tarih Vakfi Yay., İstanbul 1994, s. 473.

85 Kavanin-i Yeniçeriyan, s. 92-93. Uzunçarşılı, Kapukulu Ocaklan I, s. 254. Özcan, "Etmeydanı”, DİA, s. 497.

86 Murphey, Osmanl'da Ordu ve Savaş, s. 108, 252 (5. Bölüm dipnot 2).

87 Özcan, "Etmeydanı", DİA, s. 497.

88 Sunar, "İstanbul'da Yeniçeri Mekânları: Eski ve Yeni Odalar", s. 193.

Belleten, Aralık 2020, Cilt: 84/Sayı: 301; 983-1044 
kışlayı andıran nöbetçi binası bulunmaktaydı. ${ }^{89}$ Özellikle Yedikule selhanelerinde zebh edilen hayvanlardan her gün tayin edilen miktarda et, hayvanlara yüklenerek birkaç Yeniçeri neferinin korumasında kışlalara getirilirdi. Bu esnada çarş1pazarda bunların çevresinde dolaşmak yasaktı. Sonra tomruk adı verilen sekiz kasap dükkanı aracılığı ile her orta veya bölüğün nefer sayısına ve tayın miktarına göre belli ücret karşılığında dağıtılırdı. Et fiyatı artsa bile bu rakam değişmez aradaki fark zarar-ı lahm adıyla devlet tarafindan karşılanırdı. Bu zarar iskelelere gelen hayvanlardan alınan kasabiye akçesinden karşılanmaktaydı. ${ }^{90} \mathrm{Bu}$ sekiz adet kasap dükkanlarından her birine ikişer Hıristiyan kasap ve dörder hizmetkâr tayin edilmişti. Bu hizmetleri karşılığında kendilerinden herhangi bir vergi vs. alınmazdı. ${ }^{91}$

Kavanin-i Yeniçeriyan, "Sultan Süleyman Han zamanında tomruk tayin edip, Meydan' yaptılar. Rumeli'nde 360 bin koyun tayin edilmiştir. Eğer koyun zaran çok olursa, yoldaşlara koyun bulunmazsa, bu hazine mah koyunlardan verirler. Şimdi o koyunun üçte biri gelmez, kalanın akçesini getirirler, koyun tüccarna verirler. Her iskelede başka kasabiye tayin edilmiştir. Bunlarn zaran buradan verilir. Ama verilen gittikçe çoğalmaktadır. Çoğaltmamak gerekir. Eskiden verilegeldiği gibi vermek gerekir. Odadan odaya yarmşar koyun verilegelmistir" diyerek bu konudaki bozulmalara da dikkat çekmekte, Kanuni dönemindeki durumu idealize etmekteydi. $^{92}$

Risale, bu husustaki bilgileri 52. bölüğün ${ }^{93}$ aşçısı Ahmet Usta’nın şahsında sembolik bir anlatımla teyit eder. Buna göre padişah, Ahmet Usta'nın arzuhali neticesinde ocağın bünyesinde sekiz tomruğun tesis edilmesi, aşçıların namaz kılması için bir mescid, musluk, dehliz (ayak yolu) ve mahzen bina edilmesi emrini vermişti. Ayrıca padişah, “...tomruklarnda eğer Karaman koyunu ve keçi ve ank lahm ve bayat lahm görüb bu sekiz tomruğu virilür ise Allahü te'âlann la'neti vesâ'ir mahlûkâtın la'neti ve cümle yaradılmışlarnn la'neti ol zâbitânnn üzerine olsun" diyerek bu kasap dükkanlarında usulsüz işler yapılmaması, kanundışı uygulamaların olmamasını sıkıca tenbih etmişti. Kanuna uygun olmayan etler getirilirse sekson denilen köpeklere verilmeliydi. ${ }^{94}$

89 Sunar, "Yeniçeri Kışlaları Üzerine Bir Değerlendirme", s. 257.

90 Tarih-i Askeri-i Osmanî, s. 207, 208. Özcan, "Etmeydanı", DİA, s. 497.

91 TTKN 8a. Özcan, "Etmeydanı", DİA, s. 497. Uzunçarşılı, Kapukulu Ocaklar I, s. 254-255.

92 Kavanin-i Yeniçeriyan, s. 93. İpşirli, "Osmanlı Devlet Teşkilatına Dair Bir Eser: Kavânîn-i Osmânî ve Râbita-i Âsitâne", s. 29.

93 Yenibahçe Çayırı'na açılan kapı ile Et Kapısı olarak adlandırılan kapıları 52. ve 57. Cemaatler korumaktaydı. Bk. Sunar, "Yeniçeri Kışlaları Üzerine Bir Değerlendirme”, s. 257.

94 TTKN 7b-8a. 
Bu işlerden sorumlu olmak üzere et tomruklarının nezareti Başçavuş’a, kasap ve hademelerin nezareti de Başdeveci'ye verilmişti. ${ }^{95}$

Kışlaya gelen etin dağıtımı belli teşrifat kaidelerine göre yapılmaktaydı. Kavanin-i Yeniçeriyan'da : 'Et kışla kapılarnna vardığında, bir kasap kesilmiş koyunlarm birini kucağına alarak kışla kapısının iç tarafinda ayakta durur. Seğirdim ustası ile erleri de kışlanın ortasındaki meydanın diğer tarafinda hazır olurlar. Bu sırada kışlalardaki askerlerin görevde olmayanlarmmn hepsi meydanda toplanarak seyrederler. Baş̧̧avuş, kışla meydanında her zaman gülbang çektiği yüksek taşın üstüne çıkıp, iki kolunu Bektaşı̂ usulünde göğsüne bağlannp bir gülbang çektikten sonra: Hazır olun ağalar! Et geldi! Bildik, bilmedik demeyiniz! Ustalarmız gördükde peştemallarnnz çeviriniz! Haydi babam, haydi diye haykırır haykırmaz, bu yarısma adeta bir kale fethine eşit övünme vesilesi olup, eti kapmaya hazır olan seğirdimler bir hamlede eti kucăğnda tutmakta olan kasaba doğru seğirtip, elini kim önce vurursa, eti alır ve seğirdim erlerinin ikisi derhal herifin koltuğuna girerek, bir tur atıp kuşlasına götürürlerdi" diye anlatılmıştı. ${ }^{96}$

\section{Bedergah-Kuloğlu-Ocağa Ecnebi Girmesi}

Yeniçeri Ocağı kanununa göre Acemi Ocağı’ndan çıkanlar, kapıya çıkma veya bedergâh adı verilen bir uygulamayla bilhassa sefer zamanlarında kıdem sırasına ve ocağın münhal raporuna göre genellikle üç akçe yevmiye ile Yeniçeri Ocă̆ı'na çıkarılırlardı. ${ }^{97}$ Acemi Ocağı'nın en büyük kumandanı İstanbul Ağası’ydı. Ondan sonra Anadolu ve Rumeli Ağaları gelmekteydi. ${ }^{98}$ Zaman içinde devşirme yoluyla Acemi Ocağı'na kabullerin yanı sıra kuloğlu denilen emektar Yeniçeri çocuklarına da bu yol açılmış, XVI. yüzyılın sonlarına doğru sayıları 700’ü bulan kuloğullarından belli yaşa gelenler Acemi Ocă̆ı'na alınır olmuştu. ${ }^{99}$ Fakat buna da rüşvet

95 TTKN 8a. Uzunçarşıll, Kapukulu Ocaklan I, s. 256.

96 Kavanin-i Yeniçeriyan, s. 221-222.

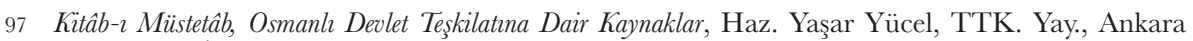
1988, s. 13. İlgürel, "Yeniçeriler", $\dot{I} A$, s. 388. Uzunçarşılı, Osmanlı Tarihi II, s. 554. Uzunçarşılı, Kapukulu Ocaklan I, s. 12, 14. Ahmed Refik, "Devşirme Usulü, Acemi Oğlanlar”, s. 1.

98 Abdülkadir Özcan, "Osmanlı Askeri Teşkilatı", Osmanl Devleti ve Medeniyeti Tarihi, I, Ed. Ekmeleddin İhsanoğlu, IRCICA, İstanbul 1994, s. 337. Kavanin-i Yeniçeriyan yazarı da dedesinin 14 yıl İstanbul Ağalığı Saka Mahmud olduğunu ifade etmişti. Bk. Kavanin-i Yeniçeriyan, s. 28.

99 İlgürel, "Yeniçeriler", $\dot{I A}$, s. 388. Irina Petrosyan, "Osmanlı İmparatorluğu’nda Askeri Reformlar Konusunda İlk Girişim: XVI. Yüzyılın Sonu İle XVII. Yüzyılın Başında Yeniçeri Ocağı”, Osmanlı, C 6, Ankara 1999, s. 673. Orhan Sakin, Kanuni döneminde sınırlı da olsa evlenmeye müsaade edildiğini, II. Selim'in tahta cülusunda kul oğullarının ocakta istihdam edildiğini yazar. (Yeniçeri Ocă̆, s. 57). 
karışmış, teftiş etmeksizin ocağa kuloğlu ${ }^{100}$ kaydedilir hale gelmişti. ${ }^{101}$ Kendisi de devşirme kökenli bir Yeniçeri olan Kavanin-i Yeniçeriyan yazarına göre, ocağın bozulmasına yol açan girişimlerin temeli devşirme uygulamasındaki usulsüzlüklere dayanmaktaydı. Yeniçeri olmaya layık olup olmama konusunda eski kanunlarda meslek, soy ve dine göre bir zorunluluk belirlenmişken, bu kurala uyulmaması ocağ1 temelinden sarsmaktaydı. ${ }^{102}$ Yeniçeriliğe kabul edilecek olanlar, Türk oldukları halde ana baba isimlerini Hıristiyan adıyla kaydederek Ağa Çırağı yapılmakta, aslını araştırmadan deftere kaydedilmekteydi. Bu uygulama başladığndan beri devşirmeye ihtiyaç kalmamıştı. Ağa çıraklığ başladığgndan beri Yeniç̧eri Ocağı’na Türk mürk dahil olup başh başına bir illet olmuştur, devşirmeye ihtiyaç kalmamıştr. Devşirmenin bozulmasina sebep bu olmuştur diyerek kanunların uygulanmadığının önemini çizmişti. ${ }^{103}$ Durum bir başka açıdan değerlendirildiğinde; Kanuni zamanından itibaren ateşli silahların kullanımının yaygınlaşmasıyla birlikte Yeniçeri sayısı hızla artmış, bu minvalde ocağa devşirme usulüne uygun olmamakla birlikte Türkler de alınmaya başlamıştır. ${ }^{104}$

Kanuni döneminden sonra yazılmış olan risale, bu durumdan doğan rahatsızlığ1 vurgulamak istercesine Kanuni zamanında kanunun uygulanış biçimine dikkat çekmektedir. "... ve ocaklu evlâdlarn ve ocak ağalarmmn hudmetlerinde kâl olmuşlardan be-dergâh eyleyeler ve kald ki yigirmi ü̧̧ yaşına kadar be-dergâh etmeyeler yigirmi ǚç yaşınadan evvel Acem oğhu kışlâsina Anadolu ve Rumili ağasina teslîm eyleyeler ve ta žîrleri oda kethüdasmin elinde olsun okusunlar İslâmm öğrensünler ahşâm oldukda oda kethüdâsı bir oda içine koyub üzerinden kapuyu berkide bu minvâl üzere terbiye olunduktan sonra be-dergâh eyleyeler" şeklinde ocağa kabul kriterlerinden bahsetmektedir. ${ }^{105}$ Öyle ki hükümdarların dahi kapuya oğlan çıkarmak hususunda geçerli kanunlara uymak durumunda olması ve yapılan suistimallere göz yummaması bir hikâyeyle somutlaştıılmıştı. Hikâyeye göre, Kanuni Sultan Süleyman Halkalı bahçesini düzenleyen Acemilerin hiz-

100 Kavanin-i Yeniçeriyan, s. 26, 112, 186.

101 Uzunçarşılı, Kapukulu Ocaklan I, s. 494.

102 Fodor, "Bir Nasihat-name Olarak Kavânîn-i Yeniçeriyan”, s. 219-220. Koyuncu, "Kavânîn-i Yeniçeriyân ve Bosnalı Müslüman Çocuklarının Devşirilmesi Meselesinin Tenkidi”, s. 195

103 Kavanin-i Yeniçeriyan, s. 24, 35.

104 Halil Inalcık, "Military and Fiscal Transformation in the Ottoman Empire, 1600-1700", Archivum

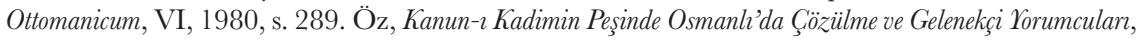
s. 47.

105 TTKN 5b. Yeniçeri Teşkilat Mecmuası, s. 5’ten naklen Uzunçarşılı, Kapukulu Ocaklan I, s. 33. Kavanin-i Reniçeriyan, s. 28. 
metlerini beğenip bunlardan üç oğlanın kanunlar çerçevesinde kapuya çıkarılması emrini verdiğinde İstanbul Ağası Saka Mahmud Ağa onlardan daha kıdemli iki Acemi'nin olduğunu belirterek toplamda beş kişinin bedergâh edilmesi için izin vermişti. Ancak Yeniçeri kâtibi kendisine mensup iki Acemi’yi de kayıt sırasında bunların arasına dahil etmişti. Defterler incelenirken bunun farkına varıldığında padişah tüm ricalara rağmen kâtibin idam emrini vermişti. ${ }^{106}$ Keza yine Edirne'de Sultan Selim Camii inşası sırasında pencere demirleri hizmetlerinden dolayı Mimar Sinan'ın mektubuna binaen yedi Acemi oğlanın kapıya çıkarılması için verilen emirde kanunlarnna göre ibaresi yer almıştı. Ahmed Refik'e göre ise, Acemi Ocağı teşkilatındaki bozulma Kanuni zamanında başlamıştı. ${ }^{107}$

1584 tarihinde Özdemiroğlu Osman Paşa’nın, yararlılı̆̆ı olanlara dokuz akçe ile bölüğe girme izni vererek ocağa ecnebilerin girmesinin yolunu açtığını 108 söyleyen Koçi Bey, kul sayısının azaltılmadan çözüm bulunamayacağını söyleyerek ümitsizliğini vurgular ${ }^{109}$ ve şu tavsiyelerde bulunur: Devşirme oğlanlar veya kul oğulları olanlar sadece bedergâh olmalıdır. Ağa çırağı, ferzend-i sipahi ve becayeş namı altındaki kanuna aykırı her uygulama kaldırılmalıdır. ${ }^{110}$

Kitab-ı Müstetab'a göre III. Murad'dan itibaren devletin adalet mekanizmasinda kusur, devlet işlerinde tedbirsizlik, ihmallerden dolayı reaya çeşitli sıkıntılara maruz kalmıştır. Hazine gelirleri giderlere yetmez olmuş, kul taifesine kanuna aykırı olarak ecnebi girmiş, devlet adamları arasında haset ve sürtüşmeler yaygınlaşmıs, rüşvet ve iltimas gibi temel sebepler yüzünden devlet-i aliyyenin temeli sarsılmıştır. ${ }^{111} \mathrm{Bu}$ eserde, kanuna aykırı devşirme yapılması şu şekilde ifade edilmişti: "kanun ve zabt ve edeb ahvallerinden evvela iç oğlanlar kadimül-eyyamdan devşürme veyahut sahih kul cinsi pişkeş olagelmişdir. Şimdiki hal ise ekseri İstanbul'un şehr oğlanlar ve Türk ve Ermeni ve Çingane oğlanlar olup on oğlanda bir sahihçe devşürme veyahut kul cinsi yokdur. Bu takdirce ol makule oğlanlar taşraya çıkub Kul taifesine zabit olup ăga oldukda veyahut memlekete vali olduklarnda ahvalleri malum ve ehl-i basiret katında hafi değildir". ${ }^{112}$ Yine burada, "reaya olanlardan Etrak ve Ekrad ve Çingane ve Tat ve Acem el-hasıl her isteyen ila'l-an varup eğer

106 Uzunçarşılı, Kapukulu Ocaklan I, s. 63, 385.

107 Ahmed Refik, "Devşirme Usulü, Acemi Oğlanlar”, s. 8, 14.

108 Koçi Bey Risalesi, Haz. Yılmaz Kurt, Akçă̆ Yay., Ankara 1998, s. 52-53, 55.

109 Koçi Bey Risalesi, s. 66-67.

110 Koçi Bey Risalesi, s. 97-98. Pál Fodor, "Bir Nasihat-name Olarak Kavânîn-i Yeniçeriyan”, s. 221.

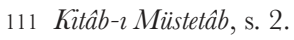

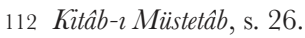

Belleten, Aralık 2020, Cilt: 84/Say1: 301; 983-1044 
seferlerde ve eğer Asitanede akça ile dirliklere geçmek ile Kul taifesine bu sebeb ile ecnebi karnşup herc ü merc olmuşlardır... ${ }^{\prime 13}$ denilerek Osmanlı Devleti'nde yaşanan bozuklukların temeli askerî sistemdeki kanun dışı uygulamalara dayandırılmaktaydı.

Risale, "Gâzi Hünkâr "benim hâs kullarm içine Acem ve Rum ve Çingâne ve Göçebe Yörük Yeniçeri olmayanlarn evlâdlarnı komaya" ${ }^{14}$ diyerek kanuna aykırı bu uygulamanın Kanuni Sultan Süleyman dönemine kadar gittiğini düşündürmekte hatta işaret etmektedir.

SKEEN ve IÜNEKN'deki “Kapucı, odalarun içine kullarumdan gayrı ecnebî kimesneyi komayasın ve avratdan ve tâze oğlandan bir kimesnenün girdügine rızâyı hümâyûnum yokdur, meger kim kul oğlı ola ve gayrı şehirlinün girdügine aslâ rızâm yokdur" ifadesi kuloğulları dışında ocağa dışarıdan girişe izin verilmediğini teyit etmektedir. ${ }^{115}$ Dolayısıyla SKEEN ve İ̈NEKN, kuloğlu uygulamasının daha Kanuni döneminde başladığını göstermektedir. TTK nüshasında da bizzat Sultanın ağzından Acem ve Rum ve Çingâne ve Göçebe Yörük gibi Yeniçeri olmayanların evlâdlarının ocağa girdiğini/girmeye çalıştıkları, ancak bunlara izin verilmediği belirtilmekte, kuloğlu ve ağa çırağı gibi kişilerin daha Kanuni döneminde bedergah edilmesinin yaygınlaştığı ve kabul gördüğü vurgulanmaktadır.

IÜNEKN ve Yeniçeri Teşkilat Mecmuası'nda da Kanuni Sultan Süleyman'a ait olduğu söylenilen aşağıdaki söz, ocağa alınacak efradın menşei ve ırklarına ne kadar ehemmiyet verildiğini göstermektedir. Şöyle ki: "el-'iyazübillah Urus ve Acem ve Çingâne ve Türk re'ayasınm evlâdlarn ve sẩir mahlûkâtın evlâdlarnn Harputl ve Diyarbekirli ve Malatyah olmaya bu yukaruda ta'yîn ve tasrîh olunanlardan gayrn âdemi ya rüşvetle veya ricâ ile veya bir büyük yerden şefa'at ile be-dergâh idüb hâlis kullarmmn aralarnda bir ecnebî korlarsa Allahü 'azîmü'ş-şanm ve yüz yigirmi dört bin peygamberlerin la'netleri ol zâbitlerin üzerlerine olsun". 116

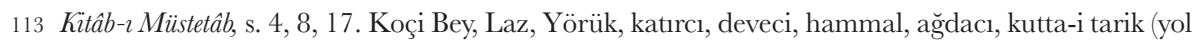
kesen), yan kesici ve sair muhtelif cinsleri de belirtir. s. 57 .

114 TTKN 5b

115 SKEEN 50b-5 1a. İÜNEKN 4a. "meğer ki kul oğulları ola ve babasından yetim kalan kul oğulları odalarına alub hıdmet itdüreler taze olduğu suretde yatsu namazından sonra oda kethüdâsı ol kul oğlın bir tenha odanın içine koyub üzerine kilitleye ve sabah oldukda oda kethüdâsı kapuyu açub yine hıdmetine meşgûl ola ve mezbûr kul oğulların bir ma'kûle kabahat zuhûr ider ise oda başısı ve vekil harcı ta'zîr itmeyüb yine oda kethüdâsı ta'zîr ide hatta kim otuz dokuz değnekden ziyâde urmaya ve mezbûr kul oğulları yigirmi üçer yaşına girmeyince be-dergâh itmeyeler ve kul oğulları ve devşirme ocak ağaların hıdmetlerinde olub bişmiş kâl olmuş hunefalarından” şeklinde ayrıntılı kriterler ifade edilmişti.

116 İÜNEKN 4a-4b. Yeniçeri Teşkilat Mecmuası, s. 5’ten naklen Uzunçarşılı, Kapukulu Ocaklan I, s. 21. 
Selânikî ise, 1590 yılında Acemi Ocağı'na devşirme alımında usulsüzlük yaşanmış olduğunu, rüşvetle Yahudi, Çingene, Rus, Çerkes, Etrak ve erazil-i haramzadelerin defterlere kaydolunduğunu ifade etmiştir. ${ }^{117}$

Oysa ki Kanuni zamanında ocağa dahil olmak bir tarafa, kışlalara bile yabancıların girmesi kanuna aykırıydı. Bu dönemde, Yeniçerilerin kışlaya yabancıları sokarak kötü hal ve hareketleri rahatsız edici boyuta geldiğinde, Sadrazam İbrahim Paşa, bunlar için odaların ortasında bir cami inşa edilmesi ve bunların kapılarının sağlam yapılıp; içeriye kadın, şarap ve yasak şeylerin girmemesi için birer kapıcı tayin edilmesi ve vakitli vakitsiz içeriye adam girmemesi konusunu padişaha arz etmişti. ${ }^{118}$

Risale bu bilgileri teyit eder mahiyette, "odalarn her bir kapusuna birer kapucu bir vukuyye lahm ta'yîn buyurub ve kapuculara emr buyurd ki "odalarmmn içine Yeniçeri kullarmmdan gayri ecnebi komayasınız ve 'avret ve taze oğlan girdiüine nzâm yokdur" deyû muhkem tenbîh eyleyüb kapulara çatal zencirler idüb lâzım geldikde açub yine kapayalar..." şeklinde odalara ecnebilerin girmemesi konusu vurgulanmaktaydı. ${ }^{119}$ Kışla binaları şehirden uzak inşa edilmemiş olduğundan Yeniçerilerin kışlalarını bir nevi bekâr odası olarak kullanması, yasak olmasına rağmen dışarıdan kadın ve içki sokmaları neticesinde odaların etrafına duvar örülmesini zorunlu kılmıştı. ${ }^{120}$ Yüksek duvarlarla çevrili olan Yeni Odalar'a Adet Kapısı, Ağa Bölüğü Kapısı, Solaklar Kapısı, Meydan Kapısı, Çayır Kapısı, Et Kapısı, Karaköy Kapısı olmak üzere yedi kapıdan girilmekteydi. ${ }^{121}$ XVII. yüzyılın sonlarında yazılmış olan Kavânîn-i Osmânî’ye göre

Solaklar Kapısı, Et Kapısı, Karaköy Kapısı ve Orta Camii Kanuni zamanında yapilmiştır. ${ }^{122}$

\section{Tekaüd-Oturak-Korucu}

Yeniçeriler, Akdeniz ve Avrupa'daki çağdaşı askerî teşkilatlarla mukayese edildiğinde yüksek ve düzenli maaş almaktaydılar. Sosyal bir devletin gereği olarak emeklilik (oturak) hakları, ihtiyaç fonu denilebilecek orta sandığı gibi bir yardım-

117 Tarih-i Selânikî, s. 220.

118 Kavanin-i Yeniçeriyan, s. 152, 154.

119 TTKN 4b.

120 Mebde-i Kanun, s. 218. Sunar, "Yeniçeri Kışlaları Üzerine Bir Değerlendirme", s. 256.

121 Sakin, Yeniçeri Ocă̆ Tarihi, s. 35.

122 İpşirli, "Osmanlı Devlet Teşkilatına Dair Bir Eser: Kavânîn-i Osmânî ve Râbıta-i Âsitâne”, s. 27. 
laşma ve dayanışma usulleri de vardı. ${ }^{123}$ Genellikle kırklı yaşlarına geldiklerinde belirli bir maaşla emekliye ayrılan Yeniçeriler, Osmanlı ticarî hayatı içerisinde rahat ve saygın yaşamlarına devam ederlerdi. Üniformayla dolaşmaya devam ederler, isterlerse kışlalarında kalabilirlerdi. ${ }^{124}$

Korucular ise, sefere çımayıp İstanbul'un ve ocağın güvenliğini korumak amacıyla görevlendirilirlerdi. Sefere çıssalar bile seferde muhafaza görevinde bulunurlardı. ${ }^{125}$ Yeniçeri odalarını ve gemilerini korumak amacıyla II. Murad'ın sefere giderken Edirne'de ulufeleriyle birkaç kişiyi tayin etmesiyle başlamıştı. Başlangıçta sayları az olan korucular zamanla ya ihtiyaca binaen ya da usulsüz uygulamalarla çoğalmışt. Sigetvar seferinde İstanbul'da 80 korucu olduğu kesindir. Odaların Caiz kapısı ile Solaklar kapısını açıp diğer kapıları kapıları kapatıp, orada yatıp o kapıları beklerlerdi. ${ }^{126}$ Kavânîn-i Osmanî’ye göre, Fatih Sultan Mehmed zamanında Edirne'de Yeniçeri odalarını beklemek üzere korucu tayin olmuş, Kara Boğdan seferinden sonra ise yaralı Yeniçerilerden korucu gediği oluşturulmuştur. ${ }^{127}$ Eyyubi Efendi Kanunnamesi'nde ise Sigetvar seferinde 1000 kişi korucu ve mütekaid olduğu ifade edilmektedir. ${ }^{128}$ Kanuni de, her ulufe dağıtımında Yeni Odalarda taht odasına gelerek burada bir süre oturur, oda zabiti olan Kul Kethüdasından 40 akçelik korucu ödeneğini alırdı. ${ }^{129}$

Mütekaid ve korucu olarak istihdam edilenlerin sayıları başlangıçta 1000'i geçmemekteyken daha sonraları yani XVII. yüzyılın başlarında 7000 sayısına ulaşmıştı. Bunlar ya İstanbul'da kalıyor ya da sefere gitse de çadırları kurmakla yükümlü olduklarından savaşa katılmıyorlardı. ${ }^{130}$ XVII. yüzyılın sonlarına doğru İstanbul'daki Yeniçerilerin çoğu mütekaid veya koruculardan oluşan ortalama

123 Kafadar, "Yeniçeriler", s. 472.

124 Goodwin, Yeniçeriler, s. 41, 69. Abdülkadir Özcan, "Osmanlı Askeri Teşkilatı", s. 344.

125 Abdülkadir Özcan, "Osmanlı Askeri Teşkilatı”, s. 344.

126 Kitâb-ı Müstetâb, s. 9-10. Kavanin-i Yeniçeriyan, s. 100, 102, 104. Tarih-i Selânikî, s. 59-60.

127 İş̧irli, "Osmanlı Devlet Teşkilatına Dair Bir Eser: Kavânîn-i Osmânî ve Râbıta-i Âsitâne”, s. 29.

128 Eyyubî Efendi Kânûnnâmesi, s. 41.

129 Sakaoğlu, "Yeni Odalar", s. 467.

130 Koçi Bey Risalesi, s. 57. Uzunçarşılı, Kapukulu Ocaklan I, s. 379. Reniçeri Teşrifat Mecmuası, s. 4'ten naklen. (burada anlaşılıyor ki teşrifat ve teşkilat şeklinde ayrı ayrı ifade edilen eser aynı eserdir). Gabor Ágoston, Osmanlı'da Savaş ve Serhad, Çev. Kahraman Şakul, Timaş Yay., İstanbul 2013, s. 143-144. 
\%30'luk kısmı ${ }^{131}$ sefere katılmaktaydı. ${ }^{132}$ Her kazada Yeniçerilerin üzerine serdar olarak bir ihtiyar korucu veya oturak tayin edilmişti. Sefer olduğunda o da İstanbul'a oda beklemeye giderdi. Ancak 1600'lerin başında korucuların sayısı çok olduğundan İstanbul'dakilerin yeterli oladuğu düşüncesiyle artık oda beklemeye de gelmemekteydiler. ${ }^{133}$

Risalede korucu ve mütekaid olanlardan şu şekilde bahsedilmekteydi: "...ta'yîn buyurub bundan sonra bin beşyüz umûr-dîde ihtiyarlara tekâü'dlük ihsân buyurub yigirmi dokuz akçe koruculuk virilüb ve kanun buyurdılar ki ne vakit padi[şa] hlar sefere gider ise beşyüz ihtiyar korucu ile bin nefer umûr-dîde teka 'üd ma'an beraber gidüb bunlar cenge girmeyüb çadır bekleyüb bir kal'anın alınması güç olub fethi müyesser olmaynca bunlar ile meşveret olunub ne gûne tedbîr iderler ise kal'anm fethi müyesser olur". ${ }^{134}$ Görüldüğü üzere Kanuni zamanında binbeşyüz tecrübeli, işten anlayan ocak mensubuna emeklilik ihsan edilerek 29 akçe maaşla korucu tayin edilmişti. Padişahlar sefere gittiğinde bunlardan beşyüzünün korucu, bininin oturak olarak yanında gitmesi kanunu konulmuştu. Sıkıntılı bir durum olduğunda kendilerinin tecrübelerinden istifade edilecek derece itimat edilen bu görevliler, çadırları bekleyecekler, savaşa aktif katılmayacaklardı.

Kanuni döneminden sonra durumun değiştiği anlaşıllyor. Gereklilikler çerçevesinde istihdam edilen korucular ve tekaüdlerin bilinmez ki odalarnnı kiremitleri mi korunurlar şeklinde ifade edilecek kadar sayıca çok ve gereksiz istihdamından bahsedilmekteydi. ${ }^{135}$ Bu durumun mali açıdan devlete yüklerini de göz ardı etmemek gerekir. ${ }^{136}$

\section{Solaklar}

Yeniçeri Ocağı'nın 60, 61, 62, 63. ortaları olan Solak ortaları padişahın muhafiz bölükleri idi. Kanuni döneminden önce sayıları seksener iken Yeniçeri sayısının artmasıyla onlar da oda başına yüz kişi olmuşlardı. Gedik oldukları için biri ölmeden yeri boşalmayınca başkasına vermezlerdi. Dolayısıyla kesinlikle yüz kişi

131 Koçi Bey’e göre seferlere nısfi değil öşrü bile katılmamaktaydı. Risale, s. 54.

132 Ágoston, Osmanlida Strateji ve Askerî Güç, s. 206-207.

133 Kavanin-i Yeniçeriyan, s. 81.

134 TTKN 4b.

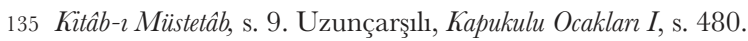

136 Yeniçeri maaş ödemeleri için hazineden ayrılan paylar hk. bk. Murphey, Osmanlı'da Ordu ve Savaş, s. 66-68. 
olurlardı. ${ }^{137}$ Cesur, uzun boylu, tecrübeli ve sözü dinlenir, hitabet kabiliyeti olan Yeniçeriler arasından usulüne uygun, bilhassa XVI. yüzyılda seğirdim aşçıları arasından seçilirlerdi. ${ }^{138}$ Kanuni, Solak ortaları dışından birinin Solakbaşı olmasını kesinlikle yasaklamıştı. ${ }^{139}$ Savaş meydanında dört Solakbaşı ile dört Kethüda ve dört Odabaşı hükümdarın atının yularına ve eteğine sıkıca yapışarak 400 kemankeş Solak padişahı her taraftan çevirirler ve hatta Silahdar, Çukadar, Rikapdar ve Dülbent ağasını bile bu çemberin dışında tutarlardı. Onlardan sonra da Yeniçeriler kuşatırlardı. Bunların dışında hiçbir askere itimat etmezler, güvenmezlerdi. ${ }^{140}$ Solakbaşı, hükümdarı yumuşak huylu ata bindirerek atın ayağına marbend veya pazubend bağlardı. ${ }^{141}$ Solakların başlarında üsküf olup kaftanları beyaz, etekleri bellerine sokulmuş ellerinde yay ve bellerinde okluk (tirkeş) vardı, zırh gömlekli idiler. $^{142}$

Solakbaşılığın ne olduğu, Solakbaşıların nasıl olması gerektiği hakkında risale bize şu bilgileri veriyor: "...ziyâde seğirden aşcrya Solaklık ihsân iderdi ve olur olmaz ademe Solaklı virmezler idi ekseri umûr-dîde oda başılara virilürdi ve genç ademe virmezlerdi oda başılarn yolu Solaklıktır meğer ihtiyâr ola bir oda başı ana etmek virile ve dahi odanin çorbacısı fevt olub veyahut yolu yürüye oda başılardan gelme Solaklara virilürdi ve Yeniçeri Ağası 'arz etmedikçe Solaklk verilmezdi ve bir çorbacı seferde şehîd oldukda Solaklık virilürdi ecnebiye ve neferâta ço $[r]$ bacılık verilmezdi kanûndur ve Gâzi Hünkâr la'net nâme yazmışdır ve Solak başılık dahi bir umûr-dìde ademe virilürdi zirâ Solak başıllk bir ulu mertebedir ve gayetle söz bilür ve umûr-dîde ve her ahvâle vukûf olmak ve padişahlarn sözün anlar ademler Solak başı olurlardı...". ${ }^{143}$

Solaklar konusundaki etraflı malûmatı Eyyubî Efendi Kânûnnâmesi'nde bulmak mümkündür. Kanunnameye göre, "kavânîn-i solagân: altmış ve altmış bir ve altmış iki ve altmuşüç, bu dört oda solaklar odalandır. Her odada yüzer solak vardır. Ziyade ve noksan kabul etmez. Yevmiyye ulufeleri dokuzar akçedir. Ĕğer oda beklerlerse yarmşar vakuyye etleri dahi vardır. Cümle solaklar çorbacı gibi süpürge giyerler. Alay oldukda beyaz gömlekler ve dört yenlü kaftan

137 Kavanin-i Yeniçeriyan, s. 158. Sakin, Yeniçeri Ocă̆l, s. 301.

138 Yeniçeri Teşrifat Defteri, s. 7, 8'den naklen Uzunçarşılı, Kapukulu Ocaklan I, s. 218. Ayrıca bk. İlgürel, "Yeniçeriler", $\dot{I} A$, s. 388.

139 Teniçeri Teşrifat Defteri, s. 8'den naklen Uzunçarşılı, Kapukulu Ocaklar I, s. 219.

140 TTKN 2a, 7a. Yeniçeri Teşrifat Defteri, s. 8'den naklen Uzunçarşıll, Kapukulu Ocaklar I, s. 219. Selânikî de Sigetvar seferinde yer alan 400 Solak'tan bahsederek bu bilgiyi teyit etmektedir. Bk. Tarih-i Selânikî, s. 27-28.

141 TTKN 7a. Yeniçeri Teşrifat Defteri, s. 8'den naklen Uzunçarşıll, Kapukulu Ocaklar I, s. 220.

142 Uzunçarşıl, Kapukulu Ocaklar I, s. 222.

143 TTKN 6b-7a. 
giyerler. Iki yenine ellerin geçirüb ve ikisin bellerine sokarlar. Ve ellerinde yay ve bellerinde kubur ile mükellef oklar götürürler. Ve hünkârn önünde piyade yürürler. Yollaryyla emîn ve kethüda ve solakbaşı olurlar. Ve 20 neferde bir düzenbaşılan vardır. Solakbaşılar semmur ve vaşak kaplu kadife üst giyerler ve sorguçlarna bahkçıl korlar. Ve atlarnna zencir ve enselik ve gümüş özengi ve topuz ve sar çizme giverler. Seferde kang yerde köprü vaki olsa inüp hünkâmn selamina dururlar. Solaklardan gayn her odada yüzer nefer yeniçeri olur. Gâhi ziyade ve gâhi noksan kabul eder". ${ }^{144}$

Bir Yeniçerinin Hatıratı adlı eserde, "sultan kendi sarayında 600 tane de atlı Tatar bulundurur. Bunların iki kumandanı vardır. Bunlara garipler subaşıları denir. Bunların her birinin kumandasında 300 kişi bulunur. Bunların adı garip yiğitleridir. Yani yetim hizmetçiler demektir. Zira bunların hepsi sultanın yetiştirmesidir. Sultan bunlardan altmış gösterişli çocuğu seçer ve birlik halinde teşkil eder. Bunlar Solak adını taşırlar. Bu birliğin kumandanının adı Solakbaşıdır. Ulufesi günde bir altındır. Bu birlik oklarla mücehhez olarak sultanın önünden gider" bilgisi verilmekteydi. ${ }^{145}$

Kanuni dönemini anlatan Batılı bir seyahatname yazarı olan Nicolas de Nicolay da, ocak içerisinde Solaklara dikkat çekmekte, Osmanlı kaynaklarını teyit edecek bilgiler vermektedir. Ona göre, güçlü, yetenekli ve en iyi ok atanlar arasından seçilirler. Pala taşırlar, her an ok atmaya hazır bir şekilde altın yaldızlı bir yayı ellerinde hazır bulundururlardı. Padişah sefere ya da camiye giderken ikişerli gruplar halinde padişahın güvenliğini sağlarlardı. Padişaha asla sırtlarını dönmezler, sağ elini kullananlar padişahın solundan, solak olanlar ise sağından yürürlerdi. ${ }^{146}$

Solakbaşılarla ilgili risalede yer almayan hususlardan bir diğeri de, padişahın gerek sefer esnasinda gerekse Bursa, Edirne, Belgrad gibi yerlerdeki gezintilerinde o şehir halkı ve esnafinın padişaha ikram olarak geçtiği yerlere serdiği payendaz olarak adlandırılan halılar ve kumaşların iş bittikten sonra Solakbaşılar ile Silahdar ve İbrikdarının arasında paylaşılmasıydı. ${ }^{147}$

144 Eyyubî Efendi Kânûnnâmesi, s. 43. Benzer bilgiler için bk. Kavanin-i Yeniçeriyan, s. 145. Ayrıca bk. İpşirli, “Osmanlı Devlet Teşkilatına Dair Bir Eser: Kavânîn-i Osmânî ve Râbıta-i Âsitâne”, s. 29.

145 Bir Yeniçerinin Hatırat, Çev. ve Yay. Haz. Kemal Beydilli, TATAV Yay., İstanbul 2003, s. 98. Konstantin Mihayloviç adlı bu şahıs, Fatih devrinde 1455'de esir edilip Yeniçeri olduktan sonra çeşitli seferlere katılmış ve firar etmiştir.

146 Nicolas de Nicolay, Muhteşem Süleyman'ın Imparatorluğunda, Ed. Marie-Christine Gomez-Geraud, Stefanos Yerasimos, Çev. Şirin Tekeli-Menekşe Tokyay, Kitap Yay., İstanbul 2014, s. 204.

147 Uzunçarşılı, Kapukulu Ocaklan I, s. 223. 


\section{Silsile-i Merâtib}

Kapıkulu Ocağı içerisinde zamanla ayrı bir önem kazanmış olan Yeniçeri Ocağı, belirli kanun ve kaidelere bağlı olarak hiyerarşik bir düzende varlığını sürdürmekteydi. Orta olarak adlandırılan her bölük hiyerarşik bir yapıda kendi başına özerk bir birim olarak yaşamaktaydı. Bu düzene uygun şekilde terfi usulü uygulanmaktaydr. ${ }^{148}$

Risalede talimhane hakkında bilgi verilirken Kanuni döneminde ocak ağalarının hiyerarşisine de değinilmektedir. Şöyle ki: “...Yeniçeriler Ağast yir öpüp tïfenk atard verâsından Kul Kethüdâsı verâsindan Sekban başı verâsından Zağarcı başı Seksoncu başı Turnacı başı ve dört Haseki ağalar ve Baş çavuş ağalar atardı verâsindan birinci Deveciler başlayub ve çorbacılar başlarnda yusufi sitâreler ile ve neferâtlanyla Gâzi Hünkârn önünde tïfenk atarlardı ve nişân uran yoldaşlara Gâzi Hünkâr bahşiş̧ ítâ iderdi cemấatler ve bölükler tamâm oldukda Seğirdim aşcularn gelïb seğirdirler idi ve et kaparlardı ve ziyâde seğirden aşcrya Solaklk ihsân iderdi...". ${ }^{149}$

Kethüda Bey, Zağarcıbaşı, Seksoncubaşı, Turnacıbaşı, Başçavuş gibi ocak ağaları, orta ve bölük kumandanlarıydılar. Bunlara, Ocak ağaları, Sanadid-i Bektaşiyan (Bektaşi seçkinleri), Ağayan-ı Bektaşiyan da denilmekteydi. Bunlar dışındakilere Yayabaşı, Bölükbaşı denilmişti. ${ }^{150}$ Genel olarak ocağın en alt kademesinden başlayarak büyüğe doğru hiyerarşik sıralama şu şekildeydi: Küçük Müteferrika, Orta Müteferrika, Baş Müteferrika, Odabaşı, Baş Odabaşı, Yayabaşı, Baş Yayabaşı, Deveci, Baş Deveci, Haseki, Baş Haseki, Turnacıbaşı, Seksoncubaşı, Zağarcıbaşı, Kethüda Bey, Sekbanbaşı. ${ }^{151}$

Eyyubî Efendi Kânûnnâmesi'nde ise, "Başböliukbaşsı, kethüda yeri olur. Badehu muhzur ağa, andan sonra haseki, badehu turnacıbaşı, badehu samsoncubaşı, badehu zağarcıbaşı, andan sonra kethüda bey olmak kanundur" denilmişti. ${ }^{152}$ Ocağın son zamanlarına kadar ufak tefek istisnaî durumlar haricinde bu terfi usulü değişmemişti. ${ }^{153}$

148 Bahaeddin Yediyıldız, "Osmanlı Toplumu”, Osmanl Devleti ve Medeniyeti Tarihi, Yay. Ekmeleddin İhsanoğlu, C I, IRCICA Yay., İstanbul 1994-1998, s. 454.

149 TTKN 6a-b.

150 Kavanin-i Yeniçeriyan, s. 57. Mebde-i Kanun, s. 192. (93b). Uzunçarşlı, Kapukulu Ocaklarn I, s. 155, 234-235. İlgürel, "Yeniçeriler", $\dot{I} A$, s. 388.

151 Kavanin-i Teniçeriyan, s. 142, 208. Tarih-i Askeri-i Osmani, s. 17. Küçükyalçın, Turna’nın Kalbi, s. 57.

152 Eyyubî Efendi Kânûnnâmesi, s. 42.

153 İpşirli, "Osmanlı Devlet Teşkilatına Dair Bir Eser: Kavânîn-i Osmânî ve Râbıta-i Âsitâne”, s. 27-28. Uzunçarşılı, Kapukulu Ocaklan I, s. 531. 
Olağanüstü durumlar haricinde rutin görevde yükselme takvimi belli bir kanun çerçevesinde yürütülmekteydi. Silsile-i merâtibin değişimi Şevval ayının sonunda yapilmaktaydı. ${ }^{154}$

\section{Ocaktan İhraç}

Yeniçeri Ocağı, kendi içinde özerk bir yapıya sahip olması dolayısıly koğuşturma ve ceza uygulamaları Yeniçeri Ăgası'nın yetkisi ve bilgisi dâhilinde yapılmaktayd. ${ }^{155}$ Suç işleyen Yeniçerilere suçunun niteliğine göre tazirden idama varan muhtelif cezalar uygulanmaktaydı. ${ }^{156}$

Bu cezalar içerisinde ocaktan ihraç anlamına da gelen tımar vermek ocak mensupları için idamdan sonraki en ağır ceza olarak kabul edilmekteydi. Öyle ki Busbecq bile Türk Mektupları adlı eserinde, geri dönüşü olmayan bir yola girdiklerini bildiklerinden Yeniçerilerin ölümden daha kötü bir ceza olarak algıladıkları merd-i kal'a veya merd-i tımar ${ }^{157}$ ilan edilerek sürgüne yollandıklarını ve sefalet içinde yaşamaya mahkûm bırakıldıklarını anlatmaktaydı. ${ }^{158}$ Risalede bu uygulamaya örnek olabilecek bir hadise şöyle anlatılmıştı: “... bir gün Gâzi Hünkâr meydana tüfenk atdırmağa gider iken odalarn içinde at başın çeküb Kul Kethüdâsın celb idüb buyurdılar ki "ben sizi odalarma üzerine nâzır ta'yîn eyledim Harem-i hassimda niçün kelb gezer korsunuz" deŷu azar idüb kapucuyu katl eylemek murâd eyledikde Kul Kethüdâsı rica idüb canın halâs eyledi mezbûr kapucuya bir tımâr virüb eline berât virüb ocakdan ihrâc buyurdılar ...". ${ }^{159}$

\section{Narh}

Osmanlı Devleti'nde halkın refahı için çeşitli sebeplerle yaşanan fiyat hareketlerinin dengelenmesi ve kontrol edilmesi maksadıyla uygulanan narh işi İhtisab müessesesinin sorumluluğundaydı. İhtisab müessesesi Osmanlı şehrinde günlük yaşa-

154 Kadrî Efendi Tarihi, s. 1161.

155 Beydilli, "Yeniçeri", Dذ், s. 456.

156 Eyyubî Efendi Kânûnnâmesi, s. 47. Telhîsü'l-Beyân ..., s. 153.

157 Merd-i Kal'a, Hisar eri, kaleleri muhafaza etmekle mükellef bir cins asker demektir. Hisar erleri, yaşlanıp yahut harbde sakatlanıp sefere gidemeyecek hale gelen yahut da bir kabahati dolayısıla ocakta tutulması artık caiz görülmeyen Yeniçerilerden tayin olunurdu. s. 152. Merd-i Trmar ise tımarlı sipahinin bir başka adı olarak ifade edilmişti. Bk. Midhat Sertoğlu, Osmanh Tarih Lûgatı, Enderun Kitabevi, İstanbul 1986, s. 222.

158 Ogier Ghislain de Busbecq, Türk Mektuplar, Doğan Kitap, İstanbul 2005, s. 108. Ayrica bk. Pul, Turnacıbaşılı, s. 112-113.

159 TTKN 5a.

Belleten, Aralık 2020, Cilt: 84/Say1: 301; 983-1044 
mın düzenlenmesi amacıyla tesis edilmişti. Günlük zaruri ihtiyaçlarını halkın en uygun ve ucuz şekilde temin etmesi belki de en önemli göreviydi. Aynı zamanda devletin büyük merkezlerinin iaşesi de önemli işlerdendi. Temel ihtiyaç maddeleri olan, buğday, et, yağ gibi maddelerin yeterli ve uygun fiyatta bulunmasını sağlamak da muhtesibin göreviydi. ${ }^{160}$

Muhtesip olacak kişinin akıllı, zeki, ilim sahibi, uğurlu ve nur yüzlü kişilerden seçilmesi, aynı zamanda çarşı-pazarda malların kalitesinden ve fiyatından da anlayacak tecrübe ve bilgiye sahip olması gerekiyordu. İhtisap Ağası, sadrazamla irtibatı en sık görevlilerden biriydi. Her çarşamba sadrazam kola çıktı̆̆ı zaman onun atının yanında değneğini tutarak yaya olarak giderdi. Sadrazam attan indiğinde Yeniçeri Ăgası değneği alır ona verirdi. Muhtesibin esnafla halk arasındaki ilişkiyi düzenleyen icraatları arasında kola çıkmak, fiyat tespiti ve kontrolü olan narh başlıca sırayı almaktaydı. ${ }^{161}$

Islahat yazarlarının da üzerinde durdukları önemli konulardan biri olan narh ${ }^{162}$ ve ihtisap müessesesi konusuna bu risalede de yer verilmiştir. Kanuni Sultan Süleyman dönemine odaklanan bu risalede, Gedik Ahmed ya da 52. bölüğün aşçısı Ahmed Usta'ya çeşitli yararlılıklarından dolayı İhtisab Ağgalığı ihsan edilmiş ve İstanbul'da etin beş akçeye çıktığından, diğer temel ihtiyaç maddelerinin pahalılığından dolayı bunun sebebini araştırması istenmişti. ${ }^{163}$ Ahmet Usta sert tedbirler alarak piyasayı düzenlemeye çalışmıştı. Vurgunculuk ve firsatçılıktan doğan karaborsanın önüne geçilmesi, piyasada mal ve fiyat dengesi sağlanması "...mezbur 'aşcr taşra çıkdıkda kol idüb ol gün yigirmi adem salb idüb ve ertesi gün kol idüb sekiz adem salb idüb ve dördüncü günü Kassâb başın ve Kethüdâsın Etmekci başıy salb idüb beşinci günü gördükim etmek vesâ'ir zahiremiz dağlar gibi yığllmış alur satar yok bir buçuk vukuyye etmek bir akçeye ve dibi kızıl mum on ikisi bir akçeye [bir] vukıyye lahm üc akçeye bir vukuyye revgan-ı sâde on bir akçeye vesẩir zahire bunlara kıyâs..." şeklinde aslında aşçı bir yana İhtisap Ağası'nın bile yetkileri ${ }^{164}$ dahilinde olmayan durumlar ifade edilmişti. Risaleye göre

160 Ziya Kazıcı, Osmanhlarda İhtisab Müessesesi, İstanbul 1987, s. 29, 34, 82-83, 93.

161 Kazıcı, Osmanllarda İhtisab Müessesesi, s. 30, 39-40, 77. Fiyat karşılaştırması için bk. Akdağ, "Yeniçeri Ocak Nizamının Bozuluşu”, s. 297-299.

162 Öz, Kanun-ı Kadimin Peşinde Osmanl’da Çözülme ve Gelenekçi Yorumculan, s. 61.

163 TTKN 8a. Kaytaz, "Osmanlı Askerî Teşkilatı Hakkında Bilinmeyen Bir Eser...”, s. 57. Devlet hizmetinde yararlılık gösteren kişilere memuriyet olarak verilebiliyordu. Bk. Kazıcı, Osmanhlarda İhtisab Müessesesi, s. 51.

164 Kazıc1, Osmanlılarda İhtisab Müessesesi, s. 16-17. Muhtesip, görevini yaparken hafiften şiddetliye doğru bir yol izler, tarif, vaaz ve nasihat konularında başkasından izin almasına gerek yoktur. 
Ahmet Ağa, hizmetlerinin karşılığı olarak beş yıl bu görevde kalmış, ${ }^{165}$ daha sonra ikinci vezir, en nihayetinde veziriazamlığa getirilmişti. ${ }^{166}$ Gedik Ahmed Paşa ismi IÜNEKN'de açıkça dile getirilmiştir. ${ }^{167}$ Ahmet Paşa, haftada bir gün büyük kol ederek, Yeniçerileri Ağası, İstanbul Kadısı ve İhtisâb Ağası'yla un kapanına inip bir kile buğdaydan un yaptırmış, numûne olarak buna göre narh verilmişti. ${ }^{168} \mathrm{Ri}$ salede 52. bölüğün aşçısı olarak ifade edilen Ahmed Ağa'nın Gedik Ahmed Paşa olması kuvvetle muhtemeldir. Ancak, Gedik Ahmed Paşa, Fatih Sultan Mehmed zamanında başarılı bir kumandan olarak karşımıza çıkmakta, Sırp ya da Arnavut devşirmesi olma ihtimali üzerinde durulmakta, Yeniçeri Ocağı mensubu olduğu bilinmektedir. 1461 yılındaki beylerbeyiliğinden öncesine herhangi bir bilgi bulunmazken, İhtisap A ğalığı’ndan veziriazamlığa kadar yükseltilmiş olduğu sadece Kavanin-i Yeniçeriyan'da hikâyeleştirilerek anlatılmıştır. ${ }^{169}$ İÜNEKN'de ise Kanuni Sultan Süleyman dönemi vurgulanarak Gedik Ahmed Paşa'dan bahsedilmiştir. ${ }^{170}$ Hatta "...etmekciler kethüdâsın salb idüb Gâzi Hünkâra 'arz olundukda ziyâde hazz idüb

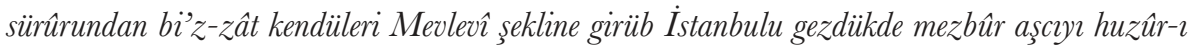
șerîflerine getürdüb hil'at-ı fâhire ihsân idüb ve bin altun in 'âm eyledi bundan sonra mezbûr aşcı kol itdikde gördü kim..." "171 şeklinde detaylandırılmıştı. Kavanin-i Yeniçeriyan'da, aşçı olan Ahmed'in koyun eti bulamadığından dolayı odaya gidemediği, görevin kendisine verildiği takdirde alacağı sıkı tedbirler neticesinde yiyeceğin bollaşacağı iddiaları üzerine Fatih Sultan Mehmed'in onu muhtesip yapması anlatılmaktadır. ${ }^{172}$

Daha evvelden de ifade ettiğimiz üzere, Gedik Ahmed Paşa tarafindan zarar-ı nân

Ancak dövme veya hapsetme gibi uygulamalarda izin alması gerekliydi. age., s. 56.

165 Oysa ki genelde uygulandığı gibi görev süresi bir yıldı. Illtizam ve bir sene müddetle ihale olunan bu görevi kabul ettiğinde bedel-i mukataa adı altında bir ödeme alınırdı. Bk. Kazıcı, Osmanhlarda İhtisab Müessesesi, s. 59-60.

166 TTKN 8b. “... bütün İstanbulu gezdükde on bir âdem navluncılardan salb idüb” ifadesi için bk. IÜNEKN $7 \mathrm{~b}$.

167 “... bir iki seneden sonra vezîr-i a'zam ahirete intikâl idüb mezbûr Gedik Ahmed Paşayn vezir idüb..." IÜUNEKN $7 \mathrm{~b}$.

168 TTKN 8b. “...kanıķılarn çorbacısı ile gelüb unkapanında karâr iderlerdi” İ̈UNEKN 8a.

169 Osmanl Sadrazamlan Hadikatü'l-Vüzerâ ve Zeylleri 3, Haz. Mehmet Arslan, Kitabevi Yay., İstanbul 2013, s. 65. Mehmed Süreyya, Sicill-i Osman̂̂, C I, Yay. Haz. Nuri Akbayar, Eski Yazıdan Aktaran: Seyit Ali Kahraman, Tarih Vakfi Yurt Yay., İstanbul 1996, s. 209. Uzunçarşılı, Osmanlı Tarihi II, s. 177-179, 533.

170 “...bunlardan sonra Gâzi Sultan Süleyman bir seneden sonra...” İ̈UNEKN 7b.

171 IÜNEKN $7 b$.

172 Kavanin-i Yeniçeriyan, s. 92-93.

Belleten, Aralık 2020, Cilt: 84/Sayı: 301; 983-1044 
ve zarar-1 lahm gibi temel ihtiyaç maddelerini satın alabilmeleri için para desteğinin sağlandığı vakf-ı nukud adı altında bir fon oluşturulmuş, bu fon onun yirmibirinci alaydaki aş̧̧ıbaşlık tecrübesine dayanılarak ihdas edilmişti. Paşa sadece askerlere mahsus kasaplar ve un pazarı (Unkapanı) açılmasını da sağlamıştır. ${ }^{173}$

Görüldüğü gibi Kanuni zamanına odaklanılan risalede Fatih döneminden bir örnek verilmiştir. Kaytaz'n da ifade ettiği üzere, yazarın anlattı̆̆ bu hikâyede amacının tarihî gerçekliğin ötesinde terfilerde liyakatin, doğruluğun, dürüstlüğün ön planda tutulması, piyasa fiyat kontrolünün halka zulmedilmemesi anlamında sıkı denetimden geçirilmesi gibi başka kaygılarının olduğu düşünülmelidir.

\section{Sonuç}

Osmanlı askerî teşkilatı içerisinde yaklaşık 500 yıllık tarihiyle Yeniçeri Ocağı hakkında tespit edilen, gün ışı̆̆ına çlkarılan ve bilim dünyasının istifadesine sunulan her kaynak mühimdir. Osmanlı askerî müesseselerinin zaman içerisinde değişim ve dönüşümünü izah etme noktasında yararlanılması zaruri olan, ancak oldukça sınırlı olan bu kaynaklar içerisinde bu risalenin şimdiye kadar Süleymaniye Kütüphanesi Esad Efendi Nüshası tespit edilmiş olup, İÜ Nadir Eserler Kütüphanesi Nüshası ise bu risalenin bir nüshası olduğunun farkına varılmadan, farklı bir başlıkla çeşitli çalışmalarda kullanılmıştır. Bu eserin risalenin bir diğer nüshası olduğu tespiti tarafimızdan yapılmıştır. Elimizde orijinal metni bulunmamakla birlikte İsmail Hakkı Uzunçarşlı'nın Hususi Kütüphanesi'nde yer alan nüshayı da burada zikretmekte fayda vardır. Bir diğer önemli husus ise TTK Nüshası'nın tespit edilerek bilim dünyasına duyurulmuş olmasıdır. Bu çalışmayla, Y/228 katalog numarasıyla TTK Kütüphanesi'nde muhafaza edilen ve sekiz varaktan oluşan bu nüshanın diğer iki nüsha ile karşılaştırmalı olarak tam metni de araştırmacıların istifadesine sunulmuştur. Bu nüshalar dışında farklı adlarla kütüphane kataloglarına girmiş veya hiç tasnif edilmemiş, hususî kütüphanelerde yer alan nüshaların da bulunma ihtimali vardır.

Kanuni Sultan Süleyman döneminden sonra yazılan ve yazılış amacı doğrudan belirtilmeyen risale, Yeniçeri Ocă̆ı'na dair bir takım kanunları, kanun-ı kadim olarak idealize edilen Kanuni dönemiyle ilişkilendirerek üstü örtülü bir kanun-1 kadim portresi çizmekte, ocağın eleştirilen yönlerine dair eskiden nasıl olduklarını, padişah-ocak ilişkisi bağlamında hatırlatma amacını gütmektedir. Yeniçerilerin

173 Kanuni Devrinde Yeniçeri Ocaklarna Dair Bazı Merasim, İstanbul Üniversitesi Kütüphanesi, Ms. T.Y. 3293, 6b-7b'den naklen Murphey, Osmanli'da Ordu ve Savaş, s. 108, 252 (5. Bölüm dipnot 2). 
sadakati, kahramanlığı, itaati, hürmeti anlatılırken padişahın da ocakla bir olma, taltif ve ödüllendirme, askerin başında sefere gitme gibi hasletleri dolaylı ve sembolik anlatımlarla öne çıkarılmaktadır. Bu anlatımlarda, ocağın bozulan ve aksayan yönleri doğrudan doğruya açık bir şekilde ifade edilmemekle birlikte, bilhassa ocağa kanuna aykırı olarak yabancıların dahil edilmesi konusuna odaklanıldığı görülmektedir. Bu yönüyle risale, Yeniçeri ocak kanunlarına dair mevcut bilgilerimizi teyit ederken, yeni bilgiler de vermesiyle önem arz eder. Risalede, Kanuni dönemi gibi erken bir tarihte açıkça ve bizzat Sultanın ağzından Acem, Rum, Çingâne ve Göçebe Yörüklerin yanı sıra Yeniçeri olmayanların evlâdlarının ocağa girdiğini/girmeye çalıştıkları dile getirilmekte, ancak bunlara izin verilmediğinin altı çizilmekte, fakat bir taraftan da kuloğlu ve ağa çırağı gibi kişilerin daha Kanuni döneminde bedergah edilmesinin kabul gördüğü ve yaygınlaştı̆̆ı belirtilmektedir. Öne çıkarılan bir diğer husus ise narh meselesidir. Temel ihtiyaç maddelerinin piyasa şartlarına uygun fiyata ve yeterli miktarda olması konusu, Gedik Ahmed Paşa'yı doğrudan işaret etmemekle birlikte onun aşçılıktan İhtisap Ağgalığı'na, oradan veziriazamlığa giden hayat hikâyesi Ahmed Usta veya Gedik Ahmed olarak aktarılmakta, onun aldığı sert tedbirlerle piyasanın ferahladığı ifade edilmektedir. Ayrıca, kışlalara su getirilmesi konusu, askerin kahramanlıkları neticesinde mükâfat olarak padişahtan para yerine kışlalarına su yolları yapılmasını istemeleri hem kışlaların tamir ve imar faaliyetlerini göstermesi hem de askerle sultan arasında cereyan eden hizmet-taltif veya fedakârlığı mükâfatlandırma münasebeti noktasindan mühimdir.

Eserini ne zaman kaleme aldığı, kime ithaf ettiği hakkında bilgi vermeyen risale yazarı, kendisi hakkında da en ufak bir ipucu dahi vermemektedir. Ancak, çeşitli hadiseler ile ocak kanunlarını anlatırken ocak mensuplarını isim ve lakaplarıyla zikrederek örneklendirmesiyle kendisinin de bir ocaklı olduğu veya bir ocak mensubundan duyduklarını aktardığı izlenimi vermektedir. Bunu, şahıs isimlerinde yaptığı yanlışlardan, tarihsel olayların gerçekliği kaygısı gütmemesinden ve zaman-mekan-şahıs çerçevesinde verdiği bilgilerden yola çıkarak söylemek mümkündür. Eser, sade ve anlaşılır üslûbuyla, yeri geldikçe canlı ve renkli anlatımıyla araştırmacılar kadar okuyucunun da ilgisini çekecek niteliktedir. 


\section{Risale Metni}

-1b- ${ }^{174}$ Merhûm ve mağfûr ${ }^{175}$ Sultan Süleyman ${ }^{176}$ 'aleyhi'r-rahmetü ve’l-gufrân ${ }^{177}$ hazretleri Bec kralı üzerine altı def'a sefer idüb hikmet-i Hüdâ altı def'ada bozulub ${ }^{178}$ yedinci def'ada ${ }^{179}$ mükemmel 'asâkir-i muvahhidîn ${ }^{180}$ ile tekrâr yine gitdikde yedi

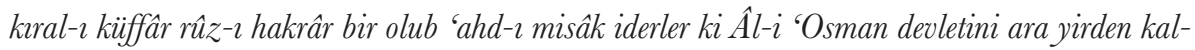
drralım deŷu tedbîr iderler ${ }^{181}$ Gâzi Hünkâr mahalline vardıkda yedi kurallar ile mukâbil oldukda cümle beğglerbeğ̀i bozulmak üzere iken Gâzi Hünkâr gördü iş gayri yüzden oluyor heman Sancağg Şerîfi ve İmam-ı a'zam hazretlerinin sancağmn getürüb ${ }^{182}$ Kul Kethüdâsı Selim Ağa ${ }^{183}$ ve Başçavuş Murtaza Ağaya ${ }^{184}$ ve Başyayabaş1 ${ }^{185}$ Deli Hamza Ağaya teslîm eyleyüb buyurdular ki "kullarm bu gün bizim Kerbela günümïzdür bu günden sonra sizelere ve bize dirlik harâmder ${ }^{186}$ İslâm gayretin elden komak sizlere lâyık değildir paygamberimiz ${ }^{187}$ aleyhi's-salatü ve's-selâmın Sancağ-1 şerîfin ve İmam-ı a'zam hazretlerinin San-

174 Sultan Süleyman Gâzi (Kırmızı mürekkeple IÜNEKN 1b); Cennet-mekân, Firdevs-âşiyân (SKEEN 48b), (IÜNEKN 1b)

175 -leh (SKEEN 48b); (IÜNEKN 1b)

176 Han (SKEEN 48b)

177 [aleyhi'r-rahmeti ve'l-gufrân] (SKEEN 48b); (IÜNEKN 1b)

178 [altı def‘ada bozulub] (İ̈NEKN 1b), fethi müyesser olmayub (İ̈̈NEKN 1b)

179 [-da] (SKEEN 48b); (IÜNEKN 1b)

180 ['asâkir-i muvahhidîn] (SKEEN 48b); [muvahhidîn] (İ̈̈NEKN 1b), İslâmla (İÜNEKN 1b)

181 “tekrâr Beç kralı üzerine sa'âdetile gitdükde yedi krallar dahi bir olup anlar dahi ahd ü yemîn iderler ki Osmanlı’yı ara yirden kaldurmak içün tedbîr iderler”. (SKEEN 48b); “tekrâr gitdikde yedi krallar bir olub öyle 'ahd ü yemîn ider ki 'Osmanlıyı ara yerden kalduralar 'azim ... idüb ve tedârikler iderler" (İUNEKN lb)

182 "Merhûm Sultân Süleymân sa'âdetile mahalline varduklarında yedi krallar ile mukâbil olup cümle beglerbegiler bozılmak sadedinde iken merhûm Sultân Süleymân görür ki küffârın tedbîri gayrı gûne ve hücûmı ziyâde bunlar da Sancă̆-1 şerîfi ve İmâm-1 a'zam hazretlerinün sancağ-1 şerîfin getürüp," (SKEEN 48b); "bu tarafdan merhûm Sultân Süleymân sa'âdetle mahalline vardıklarında yedi krallar ile mukâbil olduklarında küffâr-ı hâksârın galebesinden cümle beglerbegiler bozılmak sadedinde iken merhûm Sultân Süleymân gördü ki iş gayrı dürlü oluyor Sancağ-1 şerîfi ve İmâm-1 a'zam hazretlerinün sancağ-1 şerîfin" (IÜNEKN 1b)

183 -ya (SKEEN 48b); "Yavuz Selim Ağaya" (IÜUNEKN 1b)

184 [ya] (SKEEN 48b)

185 Yayabaşı (SKEEN 48b)

186 “teslîm idüp, buyurdı kim: "Kullarum bugün bizüm Kerbelâ'muzdur, bugünden sonra bize ve sizlere dirlik harâmdur," (SKEEN 48b); "teslîm idüp, buyurur ki "Kullarum bugün Kerbelâ günümüzdür bugünden sonra bize ve sizlere dirlik harâmdur" (İÜNEKN lb)

187 [-imiz] (IÜNEKN 1b) 
cağ-1 şerîfinden hicâb ediniz ${ }^{188}$ yârın bunların sahiblerinden ne yüz ile ${ }^{189}$ şefấat istersiniz" deyû buyurduklarında cümle -2a- Yeniçeri Ocağı ve sâ’ir ocak halk1 ${ }^{190}$ bu sözü ${ }^{191}$ istimâ $^{6192}$ eylediklerinde cümlesi canların ${ }^{193}$ ve hayatların terk idüb bin beş yüz ${ }^{194}$ serdengecdi gâzileriyle Başyayabaş ${ }^{195}$ Deli Hamza Ağaya Sancağı Şerîfi ve İmam-1 a'zam hazretlerinin sancağını ${ }^{196}$ emânet $^{197}$ idüb cümle gâziler bir uğurdan ${ }^{198}$ küffâr-1 hâksâr ${ }^{199}$ üzerine hücûm eylediklerinde ${ }^{200}$ yedi gün yedi gece ${ }^{201}$ arâm itmeyüb ${ }^{202}$ bir cenk-i 'azîm eylediler ki gözler görmüs değil ${ }^{203}$ sekizinci gün sabah namazından sonra 'inâyet-bâri ${ }^{204}$ küffâr bozulub ve her tarafdan ${ }^{205}$ cümle beğler bile ${ }^{206}$ tâze can bulub ve 'asâkir-i İslâm gayret eyleyüb' ${ }^{207}$ küffâr 'askerini ${ }^{208}$ bölük bölük itdiklerinde 'azimetlü padişahın sabr-1 ${ }^{209}$ karârı kalmayub Solak başılar ellerinden bir tefrît ${ }^{210}$ halâs olub ${ }^{211}$ Silahdar ağa ve Çukadar ağa ve Rikabdar ağa ve ${ }^{212}$ Dülbend

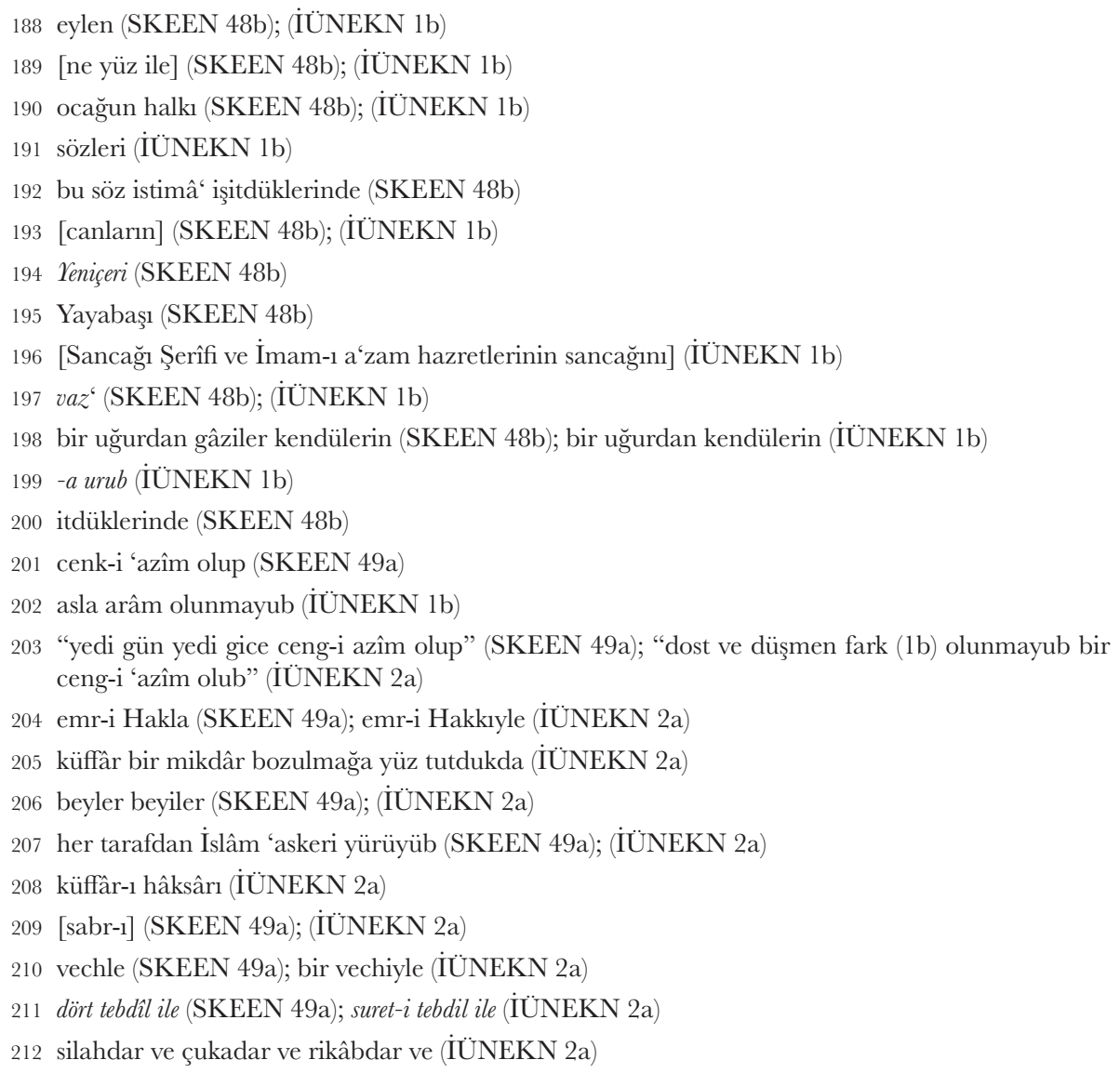


ağasıyla tebdîlan ${ }^{213}$ cenge girüb vâfir kâfir katl idüb cenk ${ }^{214}$ ederken Solak başıların 'akılları başlarından gidüb ${ }^{215}$ dört Solak baş1 ${ }^{216}$ dört Kethüdâ yeri ${ }^{217}$ ve dört Odabaşlar1 ${ }^{218}$ cenge girüb Gâzi Hünkârn taşra çıkardkklarnda Gâzi Hünkâr bi'z-zât kullarna istimâletter ${ }^{219}$ virüb "kullarum bu gün bizim ${ }^{220}$ ulu bayramımızdır böyle ${ }^{221}$ bayram bir dahi ele girmez -2b- feth ü nusret bizimdir sizlere mücde olsun"222 deyû buyurduklarında Silahdâr ağalığından gelme Rüstem Ağa Yeniçerileri' ${ }^{223}$ Ağası ve Kul Kethüdâsı ${ }^{224}$ Selim Ağa ve Baş çavuş Murtaza Ağa ve Baş yaya başı Deli Hamza Ağa Sancağ-1 şerîfi ve İmam-1 a'zam hazretlerinin Sancağ-1 şerîfíi ${ }^{225}$ önüne koyub ${ }^{226}$ cevâb ider ${ }^{227}$ ki "sa'adetlü hünkârım din-i mübîn yoluna ve $e^{228}$ hünkârımızın ${ }^{229}$ uğrına canımız fedâdır hayr du'âdan bu ${ }^{230}$ kullarını unutma ${ }^{231}$ ” didiklerinde Gâzi Hünkâr ağlayub vâfir hayr du'âlar eyleyüb ${ }^{232}$ Sancağ-1 şerîfi ve İmam-1 a'zam hazretlerinin Sancağ-1 şerîfini ${ }^{233}$ bekleyen bin beş yüz Serdengecdi gâzilerinin ${ }^{234}$ karâ-

213 [tebdilân] (SKEEN 49a); (IÜNEKN 2a)

214 küffârları katl (IÜNEKN 2a)

215 [Solakbaşıların 'akılları başlarından gidüb] (SKEEN 49a)

$216-\operatorname{lar}$ (IÜNEKN 2a)

217 Kethüdâ (SKEEN 49a); kethüdâlar (İÜNEKN 2a)

218 Odabaşı (SKEEN 49a)

219 “Gâzî Hünkâr’ı bulup, cengden taşra çıkardılar. Taşra çıdukda bi’z-zât kendüleri kullarına istimâletler" (SKEEN 49a); "Gâzî Hünkârı bulub cengden çıkardıklarında bi'z-zât kendüleri kullarına istimâletler" (IÜNEKN 2a)

220 [bizim] (SKEEN 49a); mü'minlerin (IÜNEKN 2a)

221 bayramlarıdır bu (İ̈NEKN 2a)

222 kullarm (IÜNEKN 2a)

223 Yeniçeri (SKEEN 49a); (IÜNEKN 2a)

$224 \operatorname{Yavuz~(İ̈NEKN~2a)~}$

225 [şerifi] Gâzi Hünkârn (SKEEN 49a)

226 "Baş yaya başı Deli Hamza Ağa ve Baş çavuş Murtaza Ağa Sancağ-1 şerîfleri alub Gâzi Hünkâra getürüb teslîm idüb ve cevâb iderler ki” (IÜNEKN 2a)

227 ederler (SKEEN 49a)

228 yolunda ve sa'âdetlü (IÜNEKN 2a)

229 Hünkârımun (SKEEN 49a); (IÜNEKN 2a)

230 [bu] (SKEEN 49a)

231 kullarını hayr du'âdan unutma (IÜNEKN 2a)

232 idüp (SKEEN 49a); du'âdan sonra (IÜNEKN 2a)

233 sancağın (SKEEN 49a); [Sancă̆-1 şerîfi ve İmam-1 a'zam hazretlerinin Sancağ-1 şerifini] (IÜNEKN 2a); sancağ-1 şerîfleri (IÜNEKN 2a)

234 gâzilerin (SKEEN 49a) 
$\mathrm{rl}^{235}$ kalmayub cenge girmişler idi bir kola ${ }^{236}$ Yeniçerileri ${ }^{237}$ Ağası ${ }^{238}$ ve bir kola ${ }^{239}$ Kul Kethüdâs1 ${ }^{240}$ hikmet-i bâri2 ${ }^{211}$ Yeniçerileri' ${ }^{242}$ Ağasının gitdiği kolda ${ }^{243}$ Dubrevenedik kuralna rast gelüb kural olduğun bilmeyüb başn kesüb huzûr-ı hümâyûna getürdü ve Kul Kethüdâsıyla Başşavuş bi’l-ma'îyye cenk iderlerken Zerrin ${ }^{244}$ oğlu ve Bali Beğ oğullarna rast gelïb 'azîm cenkden sonra ikisin de esîr eyleyüb huzûr-l padişahîye getïrdüler ${ }^{245}$ ve cümle Yeniçeri gâzileri ${ }^{246}$ yedi gün ${ }^{247}$ yedi gice ac ve susuz cenk idüb ${ }^{248}$ onar onar ölüb hayatlarından ümîdi kesüb ${ }^{249}$ kendülerini ol bî-pâyân küffârr ${ }^{250}$ 'askerine ${ }^{251}$ urub 'azim cenk -3a- eylediklerinde dünya durah ne gözler görmüsş ve ne olmuş ve ne olacak ertesi sabah namazndan sonra küffâr bozulub cümlesi karân firâra tebdîl eylemişlerdir ${ }^{252}{ }^{253}$ Sipahile-

235 karârları (IÜNEKN 2a)

236 tarafa (İ̈NEKN 2a)

237 Yeniçeri (SKEEN 49a); (IÜNEKN 2a)

238 gidüb (IÜNEKN 2a)

239 tarafa (İ̈NEKN 2a)

240 gidüp (SKEEN 49a); ve Baş çavus gidüb (IÜNEKN 2a)

241 Hüdâ (SKEEN 49a); (IÜNEKN 2a)

242 Yeniçeri ağası (SKEEN 49a)

243 Yeniçeri ağası gitdüğü tarafda (IÜNEKN 2a)

$244 \mathrm{R}$ harfinin üzerinde şedde vardır.

245 "kralı bulınup, yeniçeri ağası râst gelüp, kral olduġın bilmeyüp, başın kesüp huzura getürüp ve kul kethüdâsı ve başçavuş cenk ederken Zirinoğluna ve Peykan oğullarına rast gelüp azim cenkden sonra ikisin tutup esîr idüp huzur-1 hümayuna getürmüşlerdür" (SKEEN 49a); "Dubrovenedik kralı bulınub Yeniçeri ağasıyla bir hayli ceng ü cidalden sonra kral olduğın bilmeyüb başın kesüb huzûr-1 hümâyûna getürdü ve Kul kethüdâsı ve Baş̧avuş sancağ-l şeriffleri bekleyen bin beş yüz Serdengecdi gâzileri ile (2b) düşdükleri tarafda Zirinoğulları ve Palikân oğulları itmişler iki gün iki gice ac ve susuz azim cenklerden sonra firsatı Hakk te'ala Kul kethüdası ve Baş çavuş ve bin beş yüz Serdengecdi gâzilerine virüb iki melâ‘inleri tutub esir idüb huzûr-1 hümâyûna getürmüşlerdir ve" (IÜNEKN 2a2b)

246 dahi (İ̈NEKN 2b)

247 ve (IÜNEKN 2b)

248 [cenk idüb], asla arâm ve karâr olunmayub (İ̈̈NEKN 2b)

249 hayatların terk idüp (SKEEN 49b); din uğruna canların fedâ idüb (IÜNEKN 2b)

250 [küffâr] (SKEEN 49b); küffâr-1 haksâr (IÜNEKN 2b)

251 'askere (SKEEN 49b)

252 "evvel ve evvel giceye bir azîm ceng eylemişlerdür ki dünyâ duralı ne olmış ne olacakdur. İrtesi sabâh namâzından sonra küffâr askeri bi'l-külliye bozılup, karârı firâra tebdîl eylemişdür.” (SKEEN 49b); "cân u gönülden hücûm eyledilerinde öyle bir cenk eylemişlerdir ki dünyâ duralı ne olmış ne olacakdır irtesi gün sabâh namâzından sonra yedi kralların cümlesi bozulub karârı firâra tebdîl eylediklerinde" (IÜNEKN 2b)

253 bu ahvâli Gâzi Hünkâr müşâhede eyledikde atndan yere nüzul idüb mübârek yüzün toprăga sürüb şükr-i yezdân

Belleten, Aralık 2020, Cilt: 84/Say1: 301; 983-1044 
rin aşağ̊ bölï̈̆̈̈̈n ağası ve dört bölüğ̈̈n ağalarn Hünkâr tekrâr alıkoyub ${ }^{254}$ bu Silahdâr ağalarryla ma'an cenge girüb anlar dahi rûz-ı hakrârn alaylarna rast gelüb cümle toblarnn ve cebehanelerin ve hazinelerin zabt edüb Sipahiler ağası Handân Ăga gelüb Hünkâra mücde eyledi ${ }^{255}$

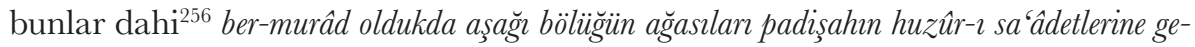
lüb "şevketlü padişahım bu gazâ-yn ekberde bu kullarn mahzun kaldık" deyû tazarru' niyâz eylediklerinden Rumili Beğlerbeğisi İslâm Paşanın ma ‘iyyetine durub Bölük ağası Sipahiler bile frrâr eden küffârn üzerine ta'yîn buyurub anlar dahi 'acele idüb frâr iden küffârnn verâsından irişü $b^{257}$ cümlesin kırub on bin iki yüz kelle ile üç bin dil alub ${ }^{258}$ huzûr-1 hümâyûna getürdiler ${ }^{259}$ ve bu cenk-i kübrâda Yeniçeriler dilâverlerinden ${ }^{260}$ yigirminci cema'atinn ${ }^{261}$ Deli Mandracı ve ${ }^{262}$ otuz iki bölüğün ${ }^{263}$ Rıdvan Usta ${ }^{264}$ ve otuz beş bölüğün Alasonyalı Deli 'Ali²65 ve otuz üç bölüğün Deli ‘'́vaz ${ }^{266}$ ve onıncu bölüğün²67

eyleyüb tekrâr atna süvâr olub (IÜNEKN 2b)

254 Önce alıkob yazıp sonra üzerine -yu eklenmiştir.

255 "Ve altı bölük sipâhîlerün aşağı bölük dört bölükleri Gâzî Hünkâr'a bekçi alıkoyup, sipâh u silâhdâr ağalarıyla ve cümle sipâh yürüyüp cenge girdüklerinde anlar dahı küffârun büyük dip alaylarına râst gelüp cümle kâfirlerün topları ve cebehâneleri ve hazînelerin zabt idüp, Sipâhîler Ağası Handân Ağa gelüp, hünkâra müjde eyleyüp" (SKEEN 49b); "sipahiler ağası ve Silahdar ağası bu ahvâli gördüklerinde dört aşağa bölük ağaların hünkârın yanlarında alıkoyub kendüleri cenge girdiklerinde küffârın dib alaylarına uğrayub cenk ü cidâl iderek küffâr bozulub cümle topların ve cebehânelerin zabt idüb sipahiler ağası Handan Ağa gelüb Gâzi Hünkâra müjde eyleyüb" (IÜNEKN 2b)

256 [dahi] (SKEEN 49b); [bunlar dahi] (İ̈̈NEKN 2b)

257 "ber-murâd olduklarında aşağı bölük ağaları hünkârun huzûrına gelüp: "Hünkârum bu gazâda bu kullarun mahrûm olduk" didüklerinde Rum-ili begler begisi İslâm Paşa ile dört bölük ağası ve sipâhîleri firâr iden küffârun ardına ta'yîn buyurup, anlar dahı acele üzre küffâra irişüp firâr iden küffârun" (SKEEN 49b); "mansûr ve muzaffer gelüb yerinde karâr eylediklerinde hünkârın yanında olan dört aşağa bölük ağaları hünkârın huzûr- şerîflerine gelüb feryâd eylediler kim "hünkârım bu dört bölük fukarâ kulların bu büyük gazâdan mahrûm kaldık" didiklerinde Gâzi Hünkâr bunların feryâdların gördükde Rumili beğlerbeğisi İslâm Paşayı ser'asker idüb ve Anatol Beğlerbeğisi Zülfikâr Paşayn ve Sivas Beğlerbeğisi Arslan Paşayı ve dört aşağa bölük ağaların ma'an ta yîn idüb zarâr iden küffârın ardına revâne oldılar sürûr ile küffara irişüb” (IÜNEKN 2b)

258 ganimet mal ile (IÜNEKN 3a)

259 getürmüşlerdir (IÜNEKN 3a)

260 [Yeniçeriler dilaverlerinden] (SKEEN 49b); (IÜNEKN 3a)

261 yoldaş (SKEEN 49b); (IÜNEKN 3a)

262 otuz dört bölï̈̆̈in Mustafa Üsküblü (IÜNEKN 3a)

263 yoldaş (SKEEN 49b); (IÜNEKN 3a)

264 [Usta], Beşe (SKEEN 49b); (IÜNEKN 3a)

265 Deli ‘Ali Alasonyalı (SKEEN 49b); Deli ‘Ali Avlonyalı (IÜNEKN 3a)

266 bölükde Deli İvaz (SKEEN 49b)

267 otuzuncu bölükde (SKEEN 49b)

Belleten, Aralık 2020, Cilt: 84/Sayı: 301; 983-1044 
Veli Baba ve on beş bölüğün ${ }^{268}$ Deli Hamza -3b- Pirlepeli ${ }^{269}$ ve on dört bölüğün Belgradi Deli Kurt bedenle? bu zikr olunan yedi 'aded neferen gâziler hem-civâr olmağla biri birlerine hevadâr ve kafadâr olmağla aynlmayub ziyâde yüz akliğzyla her birleri üçer dörder kelle dil ile gelïr iken hikmet-i bâri bunlar küçük Macar ve orta Macar kırallar ordusuna rast geldiler mezbûr gâziler hayatlarndan na-ümîd olub min tevekkelü 'alallah kendilerini ol deryâ-mânendi küffâr 'askerine urub küffâr dahi bunlara hücûm eyleyüb bunlar dahi na'ra-i Allah ü ekber sadası esmâna çıkalak bir 'azîm cenk eyleyüb 'inâyet-bâri küffâr bozulub Allahü 'azimü'ş-şan ruhsatn gâzilere virüb iki 'aded kurallar esîr idüb Gâzi Hünkârn huzûruna geldiler' 270 bu kadar baş ve dil ${ }^{271}$ ile geldiklerinde Gâzi Hünkâr ayağ üzere kalkub mübârek yüzin türâba ${ }^{272}$ sürüb mübârek ${ }^{273}$ gözlerinden yaş yerine kan akıdub "benim" ${ }^{274}$ Yeniçe$\mathrm{ri}^{275}$ kullarım gazânız mübârek olsun" ${ }^{276}$ deyû vâfir du'â eyledi ve hil'at-i fâhire giydirib iki dolu kise altûn ihsân eyleyüb mezbûr gâziler kabul itmeyüb boyunlar büküb durdılar ${ }^{277}$ Gâzi Hünkâr dahi "kullarım ihsânı niçün kabul kabul'278 itmediniz" 279 deyû buyurdukla-

268 bölüğünde (SKEEN 49b)

269 Pirlebeyeli (SKEEN 49b)

270 "on dört bölükde Deli Kurd, bu zikr olınan yedi nefer yoldaşlar hem-civâr yoldaşlar olmağla birbirlerine kafadar ve hevâdâr olup, ziyâde yüz aklug̣ı [ile] her biri üçer dörder dil ve baş alup, Gâzî Hünkâr'a gelürken hikmet-i Hudâ meger kim orta Macar kralına ve küçük Macar kralına râst gelüp, gâzîler bunları gördüklerinde hayâtları gidüp, kendülerden nâ-ümîd olup ve kendülerin küffâr askerine urup, küffâr dahı bunlara hücûm idüp, bu gâzîler bir ug̉urdan tekbîr getürüp, yürüdüklerinde Allâhu 'azîmü'ş-şân fursatı gâzîlere virüp, küffârı bozup ve iki kralları esîr idüp, Gâzî Hünkâr'a” (SKEEN 49b-50a); "on dört bölüğün Deli Kurt Belgradlı bu zikr olunan yedi nefer yoldaşlar hem-civârlar olmağla birbirlerine kafadar ve hevadar olub bu cenkde ziyâde yüz aklıkları idüb her biri üçer dörder dil ve baş alub Gâzi Hünkâra gelürken hikmet-i hüdâ Orta Macar ve Küçük Macar krallarına rast gelüb gâziler bunları gördükde hayatlarından nâ-ümid olub kendülerin küffâr 'askerine urub küffâr 'askeri dahi bunlara hücûm eylediklerinde gâziler dahi bir uğurdan tekbîr getürüb yürüdüklerinde Allâhu 'azîmü'ş-şân fursatı gâzîlere virüb küffârı bozub ve iki kralları esîr idüb huzûr-ı hümâyûna” (IÜNEKN 3a)

271 dil ve baş (İ̈NEKN 3a)

272 tobrağa (SKEEN 50a); (İ̈NNEKN 3a)

273 [mübârek] (IÜNEKN 3a)

274 [benim] (SKEEN 50a)

275 [benim Yeniçeri] (IÜNEKN 3a)

276 Hakk té 'alâ cümlenizin dest-gîri olsun (İ̈NEKN 3a)

277 "vâfir hayr du'âdan sonra bu gâzîlere birer fâhir hil'at ve birer kîse altun ihsân itdükde, mezbûr[lar] kabûl itmeyüp, boyun burup huzûrlarında durdılar." (SKEEN 50a); "vâfir hayr du'âdan sonra gâzîlere birer hil'at-ı fâhireler ihsân ve bir kîse altun in 'âm itdikde mezbûr gâziler hünkârın in âmın kabûl itmeyüb boyun burub huzûr-1 şerîflerinde durduklarında" (IÜNEKN 3a)

278 mükerrer

279 [dahi] kullarım niçün ihsânım kabul itmediniz murâdınız nedir (İUNEKN 3a)

Belleten, Aralık 2020, Cilt: 84/Sayı: 301; 983-1044 
rında 280 "şevketlï Hünkârmız ihsanınıza her bâr-4a-muhtâcız lâkin şevketlü efendimiz hazretlerinden ricâmız oldur ki İstanbulda krşlalarmizda suyumuz yokdur 'azîm zahmet çekiyoruz

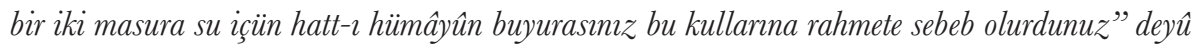
ricâ eylediler "benim gâzi oğullarm inşallah ü te'âla İstanbula vardığımızda cümle kullarrm

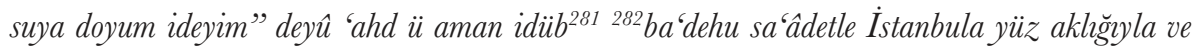
ganimet-i mal ile herkes yerlerinde karâr eylediklerinde Gâzi Hünkâr Eski Saraya biniş idüb Altı böliü̆ün Sipahiler ağalarna ve Kethüdâlarna ve Yeniçeri Ocağ halkına ve Yeniçeri kullarnna 'azîm ziyâfetler eyleyüb ve çeb akçesi yağmur misâli yağglrub ve çil para ile karı̧sdırub tepsiyle kullarna bezl idüb Yeniçeri Ă̆asına ve Kul Kethüdâsına ve Başcavuş ağaya ve sẩir ocak ağalarna hil'at-i fâhire giydirüb ${ }^{283}$ ve ba'dehu senede yüz elli kise akçe koyun akçesi ve üç ayda bir kerre her bir nefere kirkar akçe yaka akçesi ve barut akçesi ve otuz akçe keman akçesi içün hatt-ı hümâyûn ihsân buyurdılar ve serhadlerde mevcûd neferâta yamakana yevmiye ikişer akçe nafaka ve ayda birer kile halburlanmış buğday ve iki ademe bir vukyyye lahm -4b-ta'yîn buyurub bundan sonra bin beş yüz umûr-dîde ihtiyarlara tekâü'dlük ihsân buyurub yigirmi dokuz akçe koruculuk virilüb ve kanun buyurdılar ki ne vakit padi[ş] hlar sefere gider ise beşyüz ihtiyar korucu ile bin nefer umûr-dîde teka'üd ma'an beraber gidüb bunlar cenge girmeyüb çadır bekleyüb bir kal'anm alınması güç olub fethi müyesser olmaynca bunlar ile meşveret olunub ne gûne tedbîr iderler ise

280 dedükde bunlar dahı cevâb virüp, didiler kim: (SKEEN 50a); cevâb virdiler ki (IÜUNEKN 3a)

281 "Hünkârum! İhsânuna her bâr muhtâclaruz, velâkin sa'âdetlü hünkârımuzdan bir murâdımuz vardur", "Nedür kullarum?" didüklerinde, "İstanbul'da odalarımuzda su yokdur, azîm zahmetler çekerüz bir iki masura su içün, hatt-ı hümâyûn ihsân idesiz" didiler. "Kullarum! İnşâa'llâh Âsitâne'ye varduğımuzda cümle kullarumı suya doyurayum ideyüm diyü ahd [ü] yemîn eyledì" (SKEEN 50a); "Hünkârım ihsanınıza her bâr muhtacız velâkin sa'âdetlü hünkârımızdan bir murâdımız vardır" "nedir kullarım" deyû buyurduklarında "hünkârım İstanbul'da odalarımızda (3b) suyumuz yokdur 'azîm zahmetler çekilür bir iki masura sucağız ricâ ideriz hünkârımızdan" deyû cevâb virdiklerinde "olsun kullarım " deyû iki masura su içün hatt-ı hümâyûn ihsân idüb buyurdu ki "kullarım inşallahü te'alâ asitâneye varduğumuzda cümle kullarımı suya doyum ideyim" deyû 'ahd ü yemîn ider (IUÜNEKN 3a-3b)

282 bundan sonra düsmen ber taraf olub sürûr ü safâ ile (IÜNEKN 3b)

283 “Bundan sonra sa'âdetile Âsitâne’ye bu kadar yüz akluğı ile ve ganîmet ve mâl-ı firâvân ile herkes karâr-dâde olduklarında, Gâzî Hünkâr, Eski Sarây'da altı bölük ağalarına ve kethudâlarına ve Yeniçeri ocağı halkına ve Yeniçeri kullarına 'azîm ziyâfetler idüp, ziyâfetden sonra altun ile çil akçeyi harman misâl yığdurdup ve birbirine karışdırup, altun tepsi ile kullarun başlarına nisâr idüp, Yeniçeri ağasına ve kul kethudasına ve başçavuşa ve sâ’ir ocak halkına fâhir hil'atler ihsân idüp" (SKEEN 50a); sa'âdetle İstanbula gelüb kırk gün ve kırk gice 'ale's-seviye 'azîm donanmalar olub herkes karâr-dâde olduklarında sa'âdetlü hünkâr Eski Saraya teşrîf buyurub altı bölük ağalarına ve kethüdâlarına ve Yeniçeri ocağı halkına ve Yeniçeri kullarına 'azîm ziyâfet idüb ziyâfetden sonra altun ile çil akçeyi harman misâl yağdırub ve birbirlerine karışdırub altun tepsi ile kulların başlarına nisâr idüb cümle vüzerâya kürkler giydirüb ve sipah ağalarma ve kethüdâlarına 'azîm hil‘atler ihsân buyurub” (IÜNEKN 3b) 
$k$ l'ann fethi müyesser olur $^{284}$ ve bâlâda zikr olunan ziyafet sa'âdetle Gâzi Hünkâr odalara ${ }^{285}$ gelüb ta'mir sipâriş idüb ve odalarn kârizlerin ka'gîr yapdırnp ve merâmâtı lâzım mirîden virilmek üzere Şehr emîni üzerine mesârifâtın ta'yîn buyurub hatt-ı hümâyûn ihsân eylemişsir ve odalarn her bir kapusuna birer kapucu bir vukvyye lahm ta'yîn buyurub ve kapuculara emr buyurdı ki "odalarımın içine Teniçeri kullarımdan gayri ecnebi komayasınız ve 'avret ve taze oğlan girdiğine nzâm yokdur" deyû muhkem tenbîh eyleyüb kapulara çatal zencirler idüb lâzım geldikde açub yine kapayalar ${ }^{206}$ bir gün Gâzi Hünkâr meydana tüfenk atdırmağa gider iken odalarn

284 "ba'dehû senede yüz elli kîse akçe koyun akçesi ta'yîn idüp, be-her sene [50b] virilmesi içün hatt-1 hümâyûn ihsân buyurup ve yine üç ayda bir her nefere kırkar akçe yaka akçesi ve barut akçesi ve otuzar akçe kemân akçesi ta'yîn idüp ve serhadlerde neferâta ve yamak yoldaşlara günde ikişer akçe nafakaların bir kîle kalburlanmış bugday ve iki âdeme bir vakıyye lahm ta'yîn buyurup, koyundan sonra bin beş yüz umûr-dîde ihtiyârlara yigirmi tokuz akçe ile koruclluk ihsân buyurup ve bin beş yüz âdeme tekấüd ihsân buyurup ve kânûn buyurdılar kim pâdişâhlar sefere gitdükde nevbetçe beş yüz âdem umûr-dîde ihtiyâr korucı ve beş yüz umûr-dîde oturak sefere ma'an gidüp korucı [ve] oturaklar cenge girmeyüp çadırda bekçi olup bir kal'a muhâsara olup alınmak mümkin olmaduğı mahalde cengden âzâdeli kullarum ile müşâvere itmek ve anlarun re'y ile ve kal'anun fethi ne vechile olur diyü bu zikr olınan umûr-dîde ihtiyârlar bir yire gelüp müşâvere eyledüklerinde, bunlarun rây ü tedbîrleri üzre kal'anun fethi müyesser olurdı" (SKEEN 50a-50b); "ve beher sene Yeniçeri ocağına yüz elli kise koyun akçesi ta'yîn idüb beher sene virilmek içün hatt-1 hümâyûn ihsân idüb ve üç ayda bir her nefere on iki akçe yaka akçesi ve otuz akçe yay akçesi ve barut akçesi ta'yîn idüb ve serhadlerde olan neferât yoldaşlara günde birer akçe nafaka akçesi ta'yîn ve ayda bir kile kalburlanmış buğday ve iki ademe bir vukıyye lahm ta'yîn buyurub ve bundan ma'adâ bin beş yüz umûr-dîde ihtiyara korucılık ihsân buyurub kânun buyurdular ki pâdişâhlar sefere gitdikde bu nice beş yüz umûr-dîde korucı ve beş yüz umûr-dîde oturaklar ma'an sefere gidüb bu korucı oturaklar cenge girmeyüb çadırda bekçi olub (4a) bir kal'a muhâsara olub alınmak mümkün olmadığı suretde cenkden azadlu kullarım ile müşâvere eylen bu kal'anın fethi ne vechiyle olur deyû bu zikr olunan umûr-dîde ihtiyarlar bir yere gelüb müşâvere eylediklerinde anların rey ü tedbîrleri üzere kal'anın fethi müyesser olurdu" (IÜNEKN 3b-4a)

285 odulara (SKEEN 50b)

286 "ve yukarıda zikr olunan ziyâfetlerden sonra sa'âdetlü hünkâr odalara gelüb odaları ta'mir itdirüb ve cümle odaların kârizlerin muhkem kârgîr yabdırub ve meremmât lâzım geldükde şehr emini üzerine buyurub meremmâtına harc olunan akçeyi mirîden virilmek üzere hatt-ı hümâyûn ihsân buyurub odaların yedi kapusunda birer bekçi ta'yîn ve birer vakıyye lahm ihsân buyurub ve buyurdı ki: "Kapucı, odalarun içine kullarumdan gayrı ecnebî kimesneyi komayasın ve avratdan ve tâze oğlandan bir kimesnenün [5la] girdügine rızâ-yı hümâyûnum yokdur, meger kim kul oğlı ola ve gayrı şehirlinün girdügine aslâ rızâm yokdur" diyü muhkem tenbîhden sonra kapularına çatal zencîrler yapdurup, lâzım geldükde açup yine kapayalar" (SKEEN 50b-51a); "ve yukaruda zikr olunan ziyâfetlerden sonra sa'âdetlü Gâzi Hünkâr odalara gelüb odaları ta'mîr idüb cümle kârizlerin müstahkem kârgîr yapdırub ve bed yerlerde kullarım sudan zarûret çekmesün içün çeşmeler yapdırub ve meremmât lâzım geldikde şehr emini üzerine ta'yîn buyurub meremmâta harc ve sarf olunan akçe mirîden virilmek üzere hatt-1 hümâyûn ihsân idüb ve odalarda yedi kapu yapdırub her kapuda birer bekçi ta'yîn buyurub ve birer vukıyye lahm ihsân idüb ve buyururlar ki oda kapularından içerü kullarımdan gayrı ecnebî kimse komayasız ve 'avretden ve taze oğlandan bir kimesnenin girdüğüne rızâ-yı hümâyûnum yokdur meğer ki kul oğullan ola ve babasindan yetim kalan kul oğullan odalarna alub hudmet itdiureler taze olduğu suretde yatsu namaznndan sonra oda kethüdâsı ol

Belleten, Aralık 2020, Cilt: 84/Sayı: 301; 983-1044 
içinde at başın çeküb Kul Kethüdâsın celb idüb -5a-buyurdılar ki "ben sizi odalarma üzerine nâzır ta'yîn ${ }^{287}$ eyledim Harem-i hassımda niçün kelb gezer korsunuz" deyû azar idüb kapucuyu katl eylemek murâd eyledikde Kul Kethüdâsı rica idüb canın halâs eyledi mezbûr kapucuya bir tımâr virüb eline berât virüb ocakdan ihrâc buyurdılar ${ }^{288}$ ve ${ }^{289}$ bâlâda mestûr ${ }^{290}$ yoldaşları huzûr-1 sa'âdetlerine da'vet idüb"291 "kullar²92 benim ile bir ulu'293 gazâda bulundunuz elhamdülillahi te'âla emnen selâmet ${ }^{294}$ geldik ber-hudâr olunuz ${ }^{295}$ hemişe $^{296}$ yüzünüz ak olsun ricâ olunan sularmız vâfir oldu hâtınnız hoş oldu mu” deyû buyurduklarnda ${ }^{297}$ mezbûr gâziler cevâb virdiler ki "şevketlü hünkârmız gerek ta'mîr ve sularmız vâfır lâkin

kul oğgln bir tenha odanin içine koyub üzerine kilitleye ve sabah oldukda oda kethüdâsı kapuyu açub yine hudmetine meşgûl ola ve mezbûr kul oğullarn bir ma'kûle kabahat zuhûr ider ise oda başısı ve vekil harcı ta'zîr itmeyüb yine oda kethüdâsı ta'zîr ide hatta kim otuz dokuz değnekden ziyâde urmaya ve mezbûr kul oğullarn yigirmi üçer yaşına girmeyince be-dergâh itmeyeler ve kul oğullan ve devşirme ocak ağalarn hidmetlerinde olub bişmiş kâl olmuş hunefâlarnndan hatta ki el-'iyazübillah Urus ve Acem ve Çingâne ve Türk re'ayasinn evlâdlarn (4b) ve sâ'ir mahlûkâtın evlâdlarn Harputh ve Diyarbekirli ve Malatyah olmaya bu yukaruda ta'yîn ve tasrîh olunanlardan gayn âdemi ya rüşvetle veya ricâ ile veya bir büyük yerden şefa'at ile be-dergâh idüb hâlis kullarmm aralarnda bir ecneb̂̂ korlarsa Allahü 'azîmü'ş-şanın ve yüz yigirmi dört bin peygamberlerin la'netleri ol zâbitlerin üzerlerine olsun ta'yîn ve tasrîh olunan ta'ifeden gayn kimesne harem-i hassimda be-dergâh iderlerse ocağımın hâkimleri su-i hatmiye mübtelâ olub dünya ve ahiretleri harâb ola deyû la'netnâme yazılmışdır bir şehrlü âdem girdügüne rızam yokdur deyû muhkem tenbîhden sonra yedi kapularına çatal zencir yapdırub lâzım geldikde açub yine kapayalar" (IÜNEKN 4a-4b)

287 SKEEN'de ta'ayyün şeklinde yazıldığ̣ ifade olunuyor.

288 "Bir gün sa'âdetile meydâna tüfeng atdurmağa gelürken odalar içinden geçerken bir köpege râst gelüp, at başın çeker kul kethudâsın huzûrına getürür buyurur kim: "Seni odalarun üzerine nâzır ta 'yîn eyledüm, harem-i hâssumda niçün köpek korsız” diyü azâr idüp, kapucıyı katl itmek murâd ider. Kul kethudâsı şefâ'at idüp, cânın halâs ider. Mezbûr kapucıyı timarlu idüp, eline bir berât virüp, ocakdan ihrâc ider.” (SKEEN 51 la); "Gâzi Hünkâr bir gün meydâna gelüb tüfenk atdırmak içün gelürken odaların ağa kapusundan içerü girüb Yeniçeri ağası rikâbında yürürken odaların giceciler mahalline geldikde bir köpege rast gelüb sa‘âdetle at başın çeküb kul kethudâsın huzûrına da'vet idüb buyurur ki "ben seni odaların üzerine nâzır ta'yîn eyledüm, benim harem-i hâssımın niçün köpek korsın" deyû ziyâde azâr idüb ve kapucıyı öldürmek murâd eyledikde Yeniçeri ağası ricâ idüb cânın halâs idüb ve lakin mezbûrı merd-i tımar idüb eline bir berât virüb ol kapucuyı ocakdan ihrâc ider" (IÜNEKN 5a)

289 Burada tekrar su konusuna dönülüyor.

290 olan (SKEEN 51a); (İ̈̈NEKN 4b)

291 huzûrına da'vet buyurup (SKEEN 51a); huzur-1 şerîflerine da'vet buyurub (IÜNEKN 4b)

292 kullarım (SKEEN 51a); (IÜNEKN 4b)

293 büyük (SKEEN 51a); (IÜNEKN 4b)

294 yuvamıza (SKEEN 51a); [emnen ve selâmet], yuvamıza gelüb dâhil olduk (IÜNEKN 4b)

295 olun (SKEEN 51a); (IÜNEKN 4b)

296 [hemişe] (SKEEN 51a); (IÜNEKN 4b)

297 “odalarınuz ta'mîr ve suyınuz vâfir hâtırınuz hoş oldı mı?” deyü buyurduklarında” (SKEEN 5 la); "odalarınızı ta'mîr ve suyunuz vâfir hâtırınuz hoş oldı mı?” deyü buyurduklarında” (IÜNEKN 


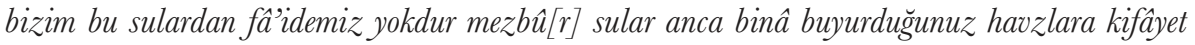

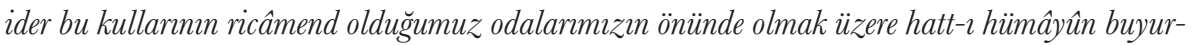
dunuz idi şevketlï efendimiz va'dine sahib-kademdir yine emr şevketlü padişahımındır" deyû boyun bükdiler Gâzi Hünkâr ol zaman "kanı sizlere virdiğim hatt-ı şerifi getürün" deyû buyurduklarnnda yigirminci cemâ'atin Deli Mandracı hatt-ı şerîfi Gâzi Hünkâra tesellüm eyledi Gâzi Hünkar dahi oda önüne iki masura su dahi $\mathbf{- 5 b}$ - odalarn önüne ta'yîn eyleyüb şimdi hâlâ yigirminci cemâ'atin evvelinden on bu böliuğüin dört bölüğün klşlasına kadar akar ${ }^{298}$ Gâzi Hünkâr "benim hâs kullarm içine Acem ve Rum ve Çingâne ve Göģebe Yörük Yeniçeri olmayanlarnn evlâdlarmı komaya ve ocaklu evlâdları ve ocak ağalarmın hıdmetlerinde kâl olmuslardan be-dergâh eyleyeler ve kald k ki yigirmi üç yaşın a kadar be-dergâh etmeyeler yigirmi üç yaşınadan evvel Acem oğlu kışlâsına Anadolu ve Rumili ağasına teslîm eyleyeler ve ta'zîrleri oda kethüdasının elinde olsun okusunlar İlâmın öğrensünler ahşâm oldukda oda kethüdâsı bir oda içine koyub üzerinden kapuyu berkide bu minvâl üzere terbiye olunduktan sonra be-dergâh eyleyeler ve mezbûr sularmı havza akıtmayub battâl iderler ise ve ecnebiden yoldaş be-dergâh iderler ise yüz yigirmi dört bin peygamberin ve evliyâlarn ve melâ'ikenin ins cin cümlesin la 'neti ol zâbitânın üzerlerine olsun" deyû la'net nâme yazub mezbûr yigirminci cemâ'atin Deli Mandracının eline virdi mezbûr odalarn ve havzlarn ta'mîri tamâm oldukda Kul Kethüdâsın üzerlerine -6a- nâzır ta'ŷ̂n buyurmuşlardır ${ }^{299}$ bundan sonra Gâzi Hünkâr At meydanına gelüb ta'lìm hâne yapdırub üzerine elli

4b)

298 Burada farklı ve SKEEN'de olmayan bir konuya geçiyor. İÜNEKN'de ise biraz daha farklı ifadelerle yer almaktadır. Be-dergâh kanunu ile ilgili bu bölüm için bk. 286. dipnot.

299 "mezbûr gâzîler cevâb virdiler kim: "Hünkârum! Hak te'âlâ ömrinüz uzun eyleye, hâtırımuz hoş, fe'emmâ kim bu sudan bu kullarun fâ'idelenmediler, bu binâ buyurdığunuz havza ancak kifâyet ider, bu kullarun murâdları odamızun öninde olmak üzre hatt-ı hümâyûn ihsân buyurmışdınuz, pâdişâhlar va'deye hilâf eylemezler, pâdişâhlarun va'desi va'de gerekdür.” didüklerinde Gâzî Hünkâr gülüp: "Kanı sizlere virdigüm hatt-ı hümâyûn getürün" diyü buyurduklarında yigirmi cemâ‘atün yoldaşı Deli Mandracı hatt-ı hümâyûnı Gâzî Hünkâr’un önine koyup, Gâzî tekrâr gülüp, iki masura su dahı ilhâk idüp [51b] ve birer çeşme dahı ol gâzîlerün hâtırları içün odalarun öninde yapdırup ve tenbîh buyurdılar kim "musluklarınuz doldukdan sonra gine havza aksun" diyü ve gine yigirmincinün bir yoldaşın mezbûr havza bekçi ta 'yîn buyurup, günde birer vakıyye lahm ve seferden mu'âf idüp, bu minvâl üzre ahdnâme yazılmışı ki: "Eger binâ eyledügüm havzları ibtâl ve suyın eksük iderler ise Allâhu azîmü'ş-şânun ve yüz yigirmi dört bin peygamberlerün ve cemî'-i melâ'ikenün ve ins ü cinnün la'neti anlarun üzerine olsun" diyü la'netnâme yazdurup, mezbûr yigirminci cemâ‘atün yoldaşı Deli Mandracı ol yedi nefer gâzîlerün ellerine virilmişdür. Ve odalar ta 'mîr olup ve su yolları ve kâzîrler ve havzlar tamâm oldukda odalarun üzerlerine kul kethudâsın ta 'yîn buyurmışlardur." (SKEEN 5 la-51b); "mezbûr gâzîler cevâb virdiler ki "Hünkârum Hakk te'âlâ ömrini uzun eyleye, hâtırımuz hoş, fe'emmâ ki bu sudan bu kullarunıza fầide olmadı, bu binâ buyurduğunuz havza ancak kifâyet ider, kullarun murâdları odamızun önünde olmak üzere hatt-ı hümâyûn ihsân buyurmuşdınız, va'deye hilâf eylemez, pâdişâhlarun va 'desi va'de gerekdir" didiklerinde Gâzî Hünkâr gülüb "Kanı sizlere virdiğim hatt-1 hümâyûnumı getürün" deyû buyurduklarında yigirminci cemâ'atin yoldaşı Deli Mandracı hatt-1

Belleten, Aralık 2020, Cilt: 84/Sayı: 301; 983-1044 
dört bölïŭgün çorbacısı ta'lîm hâne başı nasb eyleyüb tüfenk atan ok atan kemânkeşlere ta 'lim itmek içün padişahlar sefere gitdikde ta'lîm hâneci başı beraber gitmeğe me'mûrdur ${ }^{300}$ ve tüfenk atmak içün menzil yerine yonma taşlardan divâr ve orta yerlerine somaki mermerlerden nişangâh yapdrrub meteris içün somaki miller diktirüb ve millerin ardına bir büyük sofa ve yanında bir çeşme yapdurub ordan nişan vuran yoldaşlar kimine dülbend ve kimine kemân ve kimine çıın ile akçe ihsân idüb ${ }^{301}$ Gâzi Hünkâr meydâna geldikde Seksoncu başı seksonlan bir bir indirüb ve behlivanlar gelüb güreş tutarlar idi ve gürz sallarlar idi her odada birer ikişer behlivan bulunur idi ve ba'dehu Solaklar ve sâ'ir kemânkeşler hünerlerin gösterirler idi ocak ağalarn dahi gelüb tertîb üzere başlannda yusufi sitârelerle dururlar idi tüfenkciler dolu tüfenk hâzır idüb evvel Yeniçeriler Ağası yir öpüp tüfenk atardı verâsından $\mathbf{- 6 b}$ - Kul Kethüdâsı verâsından Sekban başı verâsından Zăgarcı başı Seksoncu başı Turnacı başı ve dört Haseki ağalar ve Baş çavus ă̆alar atardı verâsından birinci deveciler başlayub ve çorbacılar başlannda yusufi sitâreler ile ve neferâtlaryyla

hümâyûnı Gâzî Hünkârun eline virdükde tekrâr gülüb ve iki masura su dahi ilhâk idüb ve birer çeşme ol gâzîlerün hâtırları içün odalarun önünde (5a) yapdırub ve tenbîh buyurur ki "musluklarınız doldukda gine havza aksun" deyû ziyâde tenbîh buyururlar ve yigirmincinin bir yoldaşın mezbûr havza bekçi ta 'yîn idüb ve günde bir vukıyye lahm ihsân buyurub ve sefere gitmekden mu'âf ider bu minvâl üzere bir la'net nâme yazmışdır ki "eger binâ eylediğim havzları ibtâl ve ta'yîn eylediğim suyın eksik iderlerse Allâhu azîmü'ş-şânın ve yüz yigirmi dört bin peygamberlerin ve cemî́-i melâ'ike ve ins ü cinnin la'neti anların üzerine olsun" deyû la'netnâme yazdırub ve üzerlerine kul kethüdâsın nâzır ta 'yîn buyurub ve bu ahdnâme yazub kul ketüdâsının eline virmişdir ve odalar ta 'mîr olub ve su yolları ve kârîzler ve havzlar tamâm oldukda Gâzi Hünkâr meydana gelüb" (IÜNEKN 4b-5a)

300 "Bundan sonra Gâzî Hünkâr yeniçeri meydânına gelüp, ta'lîmhâneyi yapdu[rıv]irüp üzerlerine ta'lîmhâneci başını nâzır ta'yîn buyurup, tüfeng atan yoldaşlara ve ok atan kemânkeşlere ta'lîm itmek içün ve sefere gitmekden ve serhadde[n] mu'âf buyurup, bütün gün meydânda tüfeng ve ok atan yoldaşlara nezâret itmek içün meger kim pâdişâh sefere gitdükde ta 'lîmhâneci pâdişâhlar ile gitmege me'mûrdur." (SKEEN 51b); "Gâzî Hünkâr meydana gelüb ta'lîmhâneyi yapdırub üzerine ta 'îmmhâneci başıyı nâzır ta'yîn idüb tüfenk atan yoldaşlara ve kemânkeşlere ok atmağı ta'lîm itmek içün ve ta'lîmhâneci başıyı sefere gitmekden ve serhadlere alıkonulmakdan mu'âf buyurub bütiin gün başında yusufî ile durub tüfenk atanlara ve Solaklara ve sâ'ir kemankeşlere ta 'lîm itmeğe me'mûrdur ve pâdişâh sefere gitdikde ta 'lîmhâneci başı ile gitmeğe me’mûrdur" (IÜNEKN 5a)

301 "Ve tüfeng atılacak mahalle yonma taşdan kârgîr dîvâr ve ortasında soma mermerden nişângâh yapdırup ve metris içün somâkî mîller dikdirüp ve mîllerün ardında yonma taşdan bir büyük sofa yapdırup ve yanında bir çeşme yapdırup kendüleri oturup kulları tüfeng atdukların seyr itmegiçün, [52a] be-her sene meydâna gelüp, tüfeng atdukların seyr iderdi. Nişân uranlarun kimisine dülbend ve kimine kemân ve kimine birer çığın akçe ihsân iderdi" (SKEEN 51b-52a); "ve bundan sonra tüfenk atılacak mahalle yonma taşdan kâgîr dîvâr yapdırub ve orta yerinde somakî mermerden nişângâh yapdırub ve metris içün somakî mîller dikdirüb ve bu mîllerün ardında yonma taşdan bir büyük sofa yapdırub kendüleri sa'adetle oturmağiçün ve yanında bir çeşme bina idüb kulları tüfenk atduklarında sudan zaruret çekmemek içün beher sene Gâzi Hünkâr meydana gelüb kullarının tüfenk atdıkların seyr iderdi ve nişân uran kullarına 'azim ihsânlar iderdi ba'zı nişânı uran kullarının (5b) kimine bir dülbend ve kimine bir yay ve kimine birer çıkın akçe ihsân iderdi" (İÜNEKN 5a-5b) 
Gâzi Hünkârn önünde tüfenk atarlardı ve nişân uran yoldaşlara Gâzi Hünkâr bahş̧̧̧̧ i'tâ ider$d i^{302}$ cemâ'atler ve bölükler tamâm oldukda Seğirdim aşcrlarn gelüb seğirdirler idi ve et kaparlardı ve ziyâde seğirden aşcrya Solaklık ihsân iderdi ve olur olmaz ademe Solaklk virmezler idi ekseri umûr-dîde oda başılara virilürdi ve genç ademe virmezlerdi oda başılarn yolu Solaklıtır meğer ihtiyâr ola bir oda başı ana etmek virile ve dahi odanın çorbacısı fevt olub veyahut yolu yürüye oda başılardan gelme Solaklara virilürdi ve Yeniçeri A ğası 'arz etmedikçe Solakhk verilmezdi ve bir çorbacı seferde şehîd oldukda Solakhk virilürdi ecnebiye ve neferâta ço[r]bacılık verilmezdi kanûndur ve Gâzi Hünkâr la'net nâme yazmı̧sdır ve Solak başılık-7a-dahi bir umûr-dîde ademe virilürdi zirâ Solak başılık bir ulu mertebedir ve gayetle söz bilür ve umûr-dîde ve her ahvâle vukûf olmak ve padişahlarn sözün anlar ademler Solak başı olurlardı ve cenklerde ve seferlerde padişahlan zabt idüb ve cenk ahvâline vukûf idüb ve cenk ahvâlini padişaha ilâm idüb ve cenk mahallinde padişahlarn bindiğgi ata pazbend urub zabt iden Solak başılardan cenk mahallinde dört Solak başı bulunub ve dört Kethüdâ ve dört Oda başı hünkârn eteklerine muhkem yapısub ve dört etrâfin kuşadub dururlar Silahdâr ă̆a ve Çukadâr ağa ve Rikâpdâr ă̆a ve Dülbend ağasın padişahın yanına komazlardı Solaklarn ardında ic halkaya cenk aletlerin ellerinde dutub hâzır amâde dururlardı ve cenk olurken padişahı ve veziri a'zamı Yeniçeriler orta yerlerine alurlard ve gayni 'asâkire ${ }^{303}$ inanmazlard Yeniçerilerin orta yerlerinde karâr iderlerdi madem ki cenk bertaraf olmaynca padişahı ve veziri a'zam aralarndan sah virmezlerdi çadırlarn dört etrâfin kuşadub dururlardı muhâfaza iderlerdi kânun budur ki -7b-'ala-tari-

302 "Gâzî Hünkâr meydâna gelüp, tüfeng atmak lâzım geldükde evvel samsoncıbaşı ayuyı samsonlara pârelendir[ür] di ba'dehû pehlivânlar gelüp güreş tutarlardı ba'dehû gürz salarlardı. Ve her odada birer ikişer pehlivân bulınmak kânûndur. Ve ba‘dehû solaklar ve sâ'ir kemânkeşler gelüp hünerler gösterürlerdi ba'dehû ocak ağaları kul, kethudâsı ve başçavuş ve cümle zâbitân tertîb üzre başlarında destârlarıyla tururlardı. Evvel yeniçeri ağası yir öpüp tüfengçileri dizili tüfenge hâzır idüp atardı andan sekbânbaşı andan kul kethudâsı andan zağarcıbaşı andan saksoncıbaşı andan turnacıbaşı andan dört hâseki ağaları andan başçavuş atardı ve ba 'dehû başçavuş birinci devecilerden başlayup bölük bölük çağırup çorbacılarun başlarında Yûsufî neferâtıyla Gâzî Hünkâr'un öninde nişâna karşu koşum atarlardı. Nişân uran yoldaşlara Gâzî Hünkâr ihsân itdükden sonra" (SKEEN 52a); "ve ba'dehû meydâna gelüb sa'adetle yerinde karâr eyledikde tüfenk atmak lâzım geldikde evvel Seksoncıbaşı seksonları getürüb ayuya salıvirüb pâreletdirirdi ba'dehû pehlivânlar gelüb güreş olurdı ve her odalarda birer ikişer pehlivânlar olmak kânûndur ba'dehû gürzler sallarlardı ve ba'dehû Solaklar ve sâ’ir kemânkeşler gelüb hünerler gösterirlerdi ve ba'dehû ocak ağaları ve Kul kethudâsı ve Başçavuş ve cümle zâbitân tertîb üzere Gâzi Hünkârın huzurunda durub başlarına yusufî giyerlerdi evvel Yeniçeri ağası yer öpüb tüfenkçileri dolu tüfengi hâzır idüb eline virüb atardı andan Sekbânbaşı andan Kul kethudâsı andan Zağarcıbaşı andan Seksoncıbaşı andan Turnacıbaşı andan dört Hâseki andan Başçavuş Gâzi Hünkârın huzurunda tertîb üzere nişana kurşun atarlardı ve ba'dehû Başçavuş birinci devecilerden başlayub bölük bölük çağırub çorbacılarun başlarında Yûsufî neferâtıyla Hünkârun huzûrunda nişâna tüfenk atarlardı nişânı (6a) uran yoldaşlara 'azim ihsânlar iderdi” (IÜNEKN 5b-6a)

303 SKEEN'de olmayan önemli kelimelerden biri.

Belleten, Aralık 2020, Cilt: 84/Say1: 301; 983-1044 


\section{ki’l-icmâl beyan olund $u^{304}$ geldik yine Yeniçeri meydanına bir köşede ${ }^{305}$ Gâzi Hünkâr ${ }^{306}$ kullarına ${ }^{307}$ sadedinde iken elli iki bölüğün ${ }^{308}$ aşcısı Ahmed usta ${ }^{309}$ dimekle ma'rûf}

304 "segirdüm olan odalarun aşcıları gelüp segirdüp et kaparlardı. Ziyâde segirden aşcrya solakluk mahlûl oldukda ana ihsân olınurdı. Olur olmaz âdeme solakluk virilmezdi. Ekser umûr-dîde odabaşlara virilürdi. Uzun boylu ve kıyâfetlü âdemlere virilürdi. Bodur âdeme solakluk virilmezdi ve genç dahı olursa virilmezdi. Odabaşılarun yolı solaklukdur meger kim gâyetle amel-mânde ihtiyâr ola da etmek vireler idi. Bir odanun çorbacısı mahlûl oldukda solak olan odabaşılarun [52b] virilürdi. Yeniçeri ağası hünkâra telhîs itmedükçe solakluk virilmezdi. Ve bir çorbacı ağa seferde şehîd oldukda solaklara virilürdi, ecnebîye virilmezdi ve nefere çorbacıluk virilmemek kânûndur ve Gâzî Hünkâr la'netnâme yazmışdur ve herkes solakbaşı olmazdı. Solakbaşıluk bir umûr-dîde âdeme virilür ve bir ulu mertebedür gâyetle iş ve söz bilür ve umûr-dîde ve her ahvâle vukûf ve pâdişâhlarun sözin anlar âdemler solakbaşı olurdı. Ve cenglerde ve seferlerde pâdişâhları ceng ahvâline vâkıf idenler solakbaşlardur ve ceng mahallinde pâdişâhlarun bindügi ata bir bend uran solakbaşılardur. Ceng mahallinde dört solak başı ve dört kethudâ ve dört odabaşı hünkârun eteklerine muhkem yapışup ve dört yüz solaklar hünkârun dört etrâfın kuşadup tururlar. Silahdârı ve çukadâr ve rikâbdâr ve dülbend ağasın pâdişâhun yanında komazlar. Solaklarun ardında iç halkı top olup ceng âletleri ellerinde tururlar, hâzır u âmâde ve ceng mahallinde sa'âdetlü pâdişâhı ve vezîr-i a'zamı yeniçeriler ortasına alup tururlar, bir gayrı kula vezîr-i a'zamı ve sa'âdetlü hünkârı inanmazlar. Yeniçerilerün orta yirinde karâr iderler. Mâdâm ki ceng ber-taraf olmaya pâdişâhı ve vezîr-i a'zamı yeniçeriler çadıllarına salıvirmezler. Yeniçeriler dört etrâfın kuşadup dururlar, muhâfaza iderler. Kânûn budur ki alâ tarîkı'l-icmâl beyân olundı." (SKEEN 52a-52b); "seğirdüm olan odaların aşcıları hazır olub ve soyunub seğirdim ile et kaparlardı ziyâde seğirden aşcıya Solaklık mahlûl oldukda ânâ ihsân ve olur olmaz âdeme Solaklık virilmezdi uzun boylu ve kıyâfetlü âdemlere virilür idi genç ve bıyuklı âdemlere verilmezdi ekser umûr-dîde iş görmiş ve kal'a fethin bilür ve metris ahvâlin bilür odabaşlara virilür idi ve odabaşılarun doğru yollları Solaklıkdır meger kim ziyâde ihtiyar ve amel-mânde bir odabaşıya etmek virilürdi odanun çorbacısı mahlûl oldukda Solak olan odabaşılara virilür idi Solaklık mahlûl oldukda Yeniçeri ağası telhîs itmedikçe virilmez idi ve bir seferde çorbacı şehîd oldukda Solaklara virilürdi ecnebîye nefere çorbacılık virilmemek içün sa'adetlü ve 'azimetlü Sultan Süleyman Han Gâzi rahmetullahı 'aleyh la'netnâme yazmışıı ve herkes Solakbaşı olmaz idi Solak bir bir ulu mertebedir gayetle ma`kûl söz bilür ve gayetle umûr-dîde ve her ahvâle vâkıf ve pâdişâhlarun sözün anlar âdemler Solakbaşı olur idi ve cenglerde pâdişâhları zabt idüb ceng ahvâlin pâdişâhlara i'lâm iden iden ve ceng mahallinde pâdişâhları bir yavaş ata bindirüb ve bindüği ata bir marbend uran Solakbaşıdır ceng mahallinde dört Solak başı ve dört Kethudâlar ve dört odabaşılar sa'âdetlü hünkârun eteklerine muhkem yapışub ve dört yüz kemankeş Solaklar hünkârun dört etrâfin kuşadub dururlar Silahdârı ve Çukadârı ve Rikâbdârı (6b) ve Dülbend ağasın hünkârın yanında komazlar. Solakların ardlarında iç halkı tob olub dururlar ve ceng mahallinde sa'âdetlü ve 'azimetlü ve şevketlü pâdişâh-1 'alem-penâh hazretlerini ve vezir-i a'zam hazretlerini Yeniçeriler orta yerlerine alurlar ve gayrı kullara inanmazlar Yeniçerilerin orta yerinde olur mâdâm ki ceng ber-taraf olmaya sa'adetlü ve 'azimetlü ve şevketlü ve devletlü pâdişâh hazretlerini ve vezîr-i a'zamı çadırına salıvirmezler Yeniçeriler dört etrâfin kuşadub muhâfaza iderler kânûn budur ki alâ tarîki'l-icmâl beyân olundı." (IÜNNEKN 6a-6b)

305 [köşede], gün (IÜNEKN 6b)

306 meydana gelïb (IÜNEKN 6b)

307 tïfeng atdurmak (SKEEN 52b); (IÜNEKN 6b)

308 yigirmi birinci ağa bölüginün (SKEEN 52b); yigirmi bir ağa bölüğünün (IÜNEKN 6b)

309 Gedik Ahmed (SKEEN 52b); Gedük Ahmed (IÜNEKN 6b) 
${ }^{310}$ ve ziyade bahâdır âdem idii ${ }^{311}$ nice def ${ }^{5}{ }^{312}$ hünkârın huzûr-1 devletine ${ }^{313}$ dil ve baş getürmüş ${ }^{314}$ nice ${ }^{315}$ yararlığı sâbit olmuş idii' ${ }^{316}$ ol aşcı Gâzi Hünkâra 'arzu hal idüb dimiş ki "Hak te 'âla hünkânmızın eksikliğin göstermesün ihsân buyurlan etleri aşcı kullarn kassâb dükkânından alncaya kadar meydan beklenür ve 'azîm zahmet çekilür ihyâ buyurduğunuz et içün mücedded ihyâ buyurduğunuz meydanın bir köşesinde kassâb dükkânı idüb zâbitân

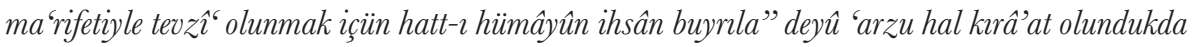
Gâzi Hünkâr kahkaha ile gülüb ${ }^{317}$ "aşc1 ${ }^{318}$ ceddim ruhiçün bu gün ${ }^{319}$ bu ahvâl benim hâtırıma geldi elhamdülillahi te âla kullarımın niyetleri ${ }^{320}$ gönül birliğine delildir" deyû ol sa'at sekiz tomruğu İstanbul içinde olan dükkânlardan ayırub meydâna vaz' idüb ${ }^{321}$ ve ba'dehu aşcllar namaz kılmak içün bir mescid binâ idüb ve bir masura su ve bir mus-

310 kimesne (İ̈NEKN 6b)

311 kimse olub (IÜNEKN 6b)

312 [Gâzi] (SKEEN 53a); (IÜNEKN 6b)

313 [devletine] huzuruna (SKEEN 53a); (IÜNEKN 6b)

314 getürüb (IÜNEKN 6b)

315 [nice] (IÜNEKN 6b)

316 olmuşdı (İ̈NEKN 6b)

317 “Ol aşcı Gâzî Hünkâr'a arz-ı hâl virüp, mefhûmında: "Hünkârum yeniçeri kullarını üçer akçe mîrî virmek üzre Kırçan koyunından bi'z-zât matbah-ı âmire[ye] giden bu kadar etler ihsân buyurdunuz. Hak te'âlâ Hünkâr'ımun eksüklüyin göstermesün velâkin ihsân buyurdugun etleri aşc1 kullarun varup kassâb dükkânlarun beklerüz, azim zahmetler çekilür. Gâzî Hünkâr'um cümle aşcı kullarına merhamet buyurup, ocağa ta'yîn buyurılan etlerimüzi bu ihyâ buyurılan meydânun bir köşesine kassâb dükkânları idüp, zâbitlerimüz ma 'rifetiyle tevzî‘ ü taksîm olınmak bâbında hatt-ı hümâyûn ihsân olına" diyü. Bu arz-ı hâl Gâzî Hünkâr kırâ’at buyurduklarında kahkaha ile gülüp" (SKEEN 53a); "evvelâ aşcı Gâzî Hünkâra arz-1 hâl virüb mefhûmında "Hünkârum Yeniçeri kullarına üçer akçe mîrî virilmek üzere kırçan koyunından bi’z-zât sa‘âdetlü hünkârımın matbah-1 'âmiresinden bu kadar etler ihsân buyurdunuz Allahü te'âlâ sa'sdetlü hünkârımın eksiklüğin göstermeyüb bu ocağa ihsân buyurdugun ihsânların 'arzına kulların şükrin itmeğe bir vechiyle iktidârları yok velakin sadaka ve ihsân buyurduğun etleri cümle aşcı kulların varub İstanbulda kassâb dükkânlarun bekler zirâ nice 'azîm zahmetler çekilür Gâzî Hünkârım hazretleri mercûdur ki cümle aşcı kullarına merhamet buyurılub ocağa sadaka ve ihsân buyurduğun etlerimizi bu ihyâ buyurduğun bir köşesinde İstanbul dükkânlarından ayırub bu gâzi kulların meydânına getürüb zâbitlerin ma'rifetiyle odalarımıza tevzî‘ ve teslîm olunmak bâbında hatt-1 hümâyûn sadaka ve ihsân oluna" deyû bu 'arz-1 hâli (7a) Gâzî Hünkâr kırâ'at buyurduklarında kahkaha ile gülüb" (IÜNEKN 6b-7a)

318 aş̧ı (IÜNEKN 7a)

319 bu gice (SKEEN 53a); (IÜNEKN 7a)

320 [niyetleri], tedbirleri (İ̈NNEKN 7a)

321 "sekiz tomruğu meydana getürüb vaz' eylemişdir" (IÜ̈NEKN 7a)

Belleten, Aralık 2020, Cilt: 84/Sayı: 301; 983-1044 
luk ve bir dehlìz binâ idüb "kullarn ta'yinât bir yerde gerekdir" deyû bir de -8a- mahzen binâ idüb mum bal pirinç revgan virilmek içün ve buyurdılar ki "kassâblar Yeniçeri kullarmmın hıdmetkârlarıdı" deyü ${ }^{322}$ her tomruğa ikişer zımmî ${ }^{323}$ dörder hıdmetkâr ta'yîn idüb ${ }^{324}$ zımmîlerin cemilesi harâcdan mu'âf olub vesâ'ir tekâlifden ${ }^{325}$ dahi mu'âf ${ }^{326}$ oldllar $^{327}$ Gâzi Hünkâr ${ }^{328}$ mübârek eline kalem alub bir hatt-1 hümâyûn tahrîr buyurub"329 "benim Yeniçeri $^{330}$ kullarımın tomruklarında eğer Karaman koyunu ve keçi ve ${ }^{331}$ arık lahm $^{332}$ ve bayat lahm görüb ${ }^{333}$ bu sekiz tomruğ ${ }^{334}$ virilür ise Allahü te '́lantn la'neti vesâ'ir mahlûkâtın la'neti ve cümle yaradılmıslarn la'neti olzâbitânmn üzerine olsun" deyû la'net nâme tahrîr eyleyüb Baş çavuş ağaya üzerlerine nâzır ta'yîn buyurub ve Baş deveciyi kassâblarn üzerine hâkim nasb idüb ve tenbîh buyurdular ki "kassâblar kullarma Karaman koyunu ve keçi bayat et getürürler ise pâreleyüb seksonlara virüb tekrâren ziyâdesiyle a lâ et getüreler"

322 "ba'dehû aşçılara namâz kılmak içün bir mescid binâ idüp ve bir masura su ve bir musluk binâ idüp ve ayak yolı ve kullarımun ta'âmâtı bir yirde gerekdür diyü meydânda bir mahzen binâ itdürüp bal ve yağ ve pirinc ve mum virilmek içün ve buyurdılar kim, "Bu kassâblar şimdengirü yeniçeri kullarımun hidmetkârı oldı" diyü" (SKEEN 53a); "ba“dehû aşçlara namâz kılmak içün bir mescid binâ idüb ve bir masura su virmek üzere ve bir musluk ve ayak yolı binâ idüb ve kullarımın yemek ta yînâtı yerde gerekdir deyû meydânda bir mahzen binâ idüb yağ ve bal ve pirinc ve mum virilmek içün ve buyurur ki "şimdi bu kassâblar Yeniçeri kullarımın hidmetkârı oldı" deyû" (IÜNEKN 7a)

323 usta ve (IÜNEKN 7a)

324 buyurdı (IÜNEKN 7a)

325 Tekâlif-i şakka (SKEEN 53a)

326 ve müsellem (SKEEN 53a)

327 ve bu zımmîlerin cümlesin harâcdan vesâ’ir tekâlif alnmak içün mu'âf ve müsellem itmişlerdir (IÜNEKN 7a)

328 [Gâzi Hünkâr] (İ̈̈NEKN 7a)

329 yazmışır (SKEEN 53b); yazmışdır ki (IÜNEKN 7a)

330 [Yeniçeri] (IÜNEKN 7a)

331 etleri vesâir (IÜNEKN 7a)

332 [lahm] (IÜNEKN 7a)

333 etler getürüb (İ̈NEKN 7a)

334 tomrukda kullarıma virürlerse (IÜNEKN 7a)

Belleten, Aralık 2020, Cilt: 84/Sayı: 301; 983-1044 
deyû hatt-ı hümâyûn tahrîr ihsân buyurub Baş çavuş ağanın eline teslìm eyledi ${ }^{335}{ }^{336} \mathrm{ve}^{337}$ iki seneden ${ }^{338}$ sonra Gedik Ahmed didikleri 'aşcry ${ }^{339}$ meşin ile divân-1 hümâyûna ${ }^{340}$ getürüb $^{341}$ meşin $^{342}$ üzerine hil'at-1 fâhire ${ }^{343}$ giydirüb İhtisâb Ağgalığ1 ${ }^{344}$ ihsân buyurub emr eyledi ki ${ }^{345}$ "bu şehrde et $^{346}$ beş $^{347}$ akçeye çıkdı -8b- ve sâ'ir zahire ${ }^{348}$ bahâya çıdı aslı üzere ahvâli i lâma hâcet yokdur ahvâli ash üzere bilüb emrine muhâlefet idenlerin haklarnndan gelesin rikâb-ı hümâyûnuma ilâma hâcet yokdur" deyû tenbîh idüb ${ }^{349}$ mezbur 'aşcı taşra çıkdıkda kol idüb ol gün ${ }^{350}$ yigirmi adem salb idüb ve ertesi gün kol

335 "Allah'un la'neti ve ins ü cinnün ve cemî‘ yaradılmışun la'neti anun üzerine olsun" diyü ve başçavuş üzerlerine nâzır ta'yîn buyurup ve başdeveciyi zimmî kassâblarun üzerine hâkim nasb ve tenbîh buyurdı kim, "Meydân kassâbları eger kullaruma ayrık eger Karaman ve keçi ve dişi etlerin getürürler ise saksonlara pâreleyüp, tekrâr ziyâde eyüsinden getüreler" diyü hatt-ı hümâyûn ihsân idüp, baş̧̧avuşun eline virmişdür" (SKEEN 53b); "üzerlerine nâzır ta'yîn olunan Başçavuş ve mezbûr zimmîlerin üzerine hâkim eylediğim Başdeveci bir vechiyle rızâ virüb veyahud iğmâz-1 'ayn iderlerse Allahü 'azîm ins ü cinnin ve cemî‘ yaradılmışın la'neti anların üzerine olsun” deyû bu minvâl üzere te'kîd ile bir la'netnâme yazdırub Başçavuş ve mezbûr Başdevecinin eline hatt-ı hümâyûn virdi kim "bu zımmî meydân kassâbları eğer kullaruma arık veyahûd Karaman koyunu ve keçi etleri veya bayat etler getürürlerse seksonlara virile" deyû bu minvâl üzere her şeyi tertîb eyleyüb" (IÜNEKN 7a)

336 bâlâda mestûr olduğı üzere merhum Gâzi Hünkâr Teniçeri ocağı halkna muhabbet eyleyüb bu kadar ihsânlar (7b) idïb yedi daf'a la'netnâme yazub birin Kul kethüdasina ve birin Baş̧̧avuşa ve birin Başdeveciye ve birin yedi nefer gâzilere virmişdir (IÜNEKN 7a-7b)

337 bir (SKEEN 53b)

338 bunlardan sonra Gâzi Sultan Süleyman bir seneden sonra (IÜNEKN 7b)

339 aşcı Gedik Ahmedi (SKEEN 53b); (IÜNEKN 7b)

340 divâna getürdüb (IÜNEKN 7b)

341 çağırıp (SKEEN 53b)

342 [meşin] (IÜNEKN 7b)

343 kaftan (SKEEN 53b); (IÜNEKN 7b)

$344-n$ (IÜNEKN 7b)

345 [emr eyledi ki] eline bir kavi hatt-ı hümâyûn virdi kim (İ̈NEKN 7b)

346 lahm (IÜNEKN 7b)

$347-e r$ (IÜNEKN 7b)

348 zehâ'ir kim kezalik (IÜNEKN 7b)

349 "ahvâlin bil emrine muhâlefet idenlerün haklarından gel, rikâb-ı hümâyûnuma arza ihtiyâc yokdur, göreyüm seni!" diyü tenbîh buyurup," (SKEEN 53b); "ahvâlin bil ve eğle emrime muhâlefet iden kimesnenin hakkından gel rikâb-ı hümâyûnuma arza ihtiyâc değildir göreyüm seni er ol baş yar sonra senin hakkından gelürüm" deyû ziyâde tenbîh ve te'kîdden sonra (IÜNEKN 7b)

350 bütün İstanbulu gezdükde on bir âdem navlunclardan salb idüb (IÜNEKN 7b) ve irtesi gün

Belleten, Aralık 2020, Cilt: 84/Say1: 301; 983-1044 
idüb $^{351}$ sekiz adem salb idüb ve dördüncü günü Kassâb başıyı ve Kethüdâsını Etmekci başıy $\imath^{352}$ salb idüb beşinci günü gördükim ${ }^{353}$ etmek vesâ’ir zahiremiz ${ }^{354}$ dağlar gibi yığılmış alur satar yok ${ }^{355}$ bir buçuk ${ }^{356}$ vukıyye etmek bir akçeye ve ${ }^{357}$ dibi kızıl mum on ikisi bir akçeye $^{358}$ [bir] vukıyye lahm üç akçeye bir vukıyye revgan-1 sâde ${ }^{359}$ on bir akçeye vesâ'ir zahire bunlara kuyâs bu minvâl üzere ${ }^{360}$ beş sene İhtisâb Ağalığı idüb ${ }^{361}$ ziyâde zâbit olmağla ${ }^{362}$ Gâzi Hünkâr ${ }^{363}$ ikinci vezir idüb ${ }^{364}$ sonra vezir-i a zam ahirete intikâl idüb baş vezir olmuşdur ${ }^{365}$ haftada bir gün büyük kol idüb ve Yeniçerileri Ağası ve İstanbul Kadısı İhtisâb Ağası un kapanına inüb ${ }^{366}$ bir kile buğdayı alub un itdirib $^{367}$ numûne didikleri budur ${ }^{368}$ ana göre narh virirler idii ${ }^{369}$ ve's-selâm tamâm oldu ${ }^{370}$.

351 on beş âdem salb idüp, irtesi gün kol (SKEEN 53b); [yigirmi âdem salb idüb] irtesi gün kol itdikde (IÜNEKN 7b)

352 ve etmekcilerün ba'zisın (SKEEN 53b)

353 "kassâbbaşıyı ve kassâblar kethüdâsın ve etmekcibaşıyı ve etmekciler kethüdâsın salb idüb Gâzi Hünkâra 'arz olundukda ziyâde hazz idüb sürûrundan bi'z-zât kendüleri Mevlevî şekline girüb İstanbulu gezdükde mezbûr aşccyn huzûr-ı şerîflerine getürdüb hil'at-ı fâhire ihsân idüb ve bin altun in 'âm eyledi bundan sonra mezbûr aşcı kol itdikde gördü kim" (IÜNEKN 7b)

354 et ve etmek [vesair zahiremiz] (SKEEN 53b); et ve ekmek vesâ'ir eşyâ (IÜNEKN 7b)

355 bir vukryye lahm ve üç akçeye (IÜNEKN 7b)

356 bir vukvyye iki yüz dirhem (SKEEN 53b)

357 bir vukuyye revgân-ı sâde ve sâfi on akçeye (IÜNEKN 7b)

358 on iki kutı kızl mum (SKEEN 53b); (IÜNEKN 7b)

359 vü sâfi (SKEEN 53b); [vukıyye lahm üç akçeye bir vukıyye revgan-1 sâde] (IÜNEKN 7b)

360 eşyâ buna göre (SKEEN 54a); eşyâlar buna göre (IÜNEKN 7b)

361 ağası olub (İ̈NEKN 7b)

362 olduğu ecilden (SKEEN 54a); (IÜNEKN 7b)

363 sonra (SKEEN 54a)

364 eyleyüp (SKEEN 54a)

365 "kubbe-nişîn oldukda iki seneden sonra vezîr-i a'zam merhûm oldukda vezîr-i a'zam olup" (SKEEN 54a); kubbe-nişîn oldukda bir iki seneden sonra vezîr-i a 'zam ahirete intikâl idüb mezbûr Gedik Ahmed Paşayn vezir idüb (İÜNEKN 7b)

366 karâr idüp (SKEEN 54a); Yeniçeri ağasıyla ve İstanbul efendisi ve İhtisâb ağası ve kayıkçılarn çorbacısı ile gelüb unkapanında karâr iderlerdi (IÜUNEKN 8a)

367 ve yoğurup etmek tabh itdükde (SKEEN 54a); ve yoğurdub etmek tabh itdikde (IÜNEKN 8a)

368 ba'dehû (SKEEN 54a)

369 iderlerdi (SKEEN 54a); (IÜNEKN 8a)

370 [tamam oldu] (SKEEN 54a); (IÜNEKN 8a) 


\section{KAYNAKLAR}

Avusturya Seferine Dair Bir Risale, Y/228, Türk Tarih Kurumu Kütüphanesi Yazmalar Kataloğu.

Ágoston, Gábor, Osmanlida Savaş ve Serhad, Çev. Kahraman Şakul, Timaş Yay., İstanbul 2013.

Ágoston, Gábor, Osmanl’da Strateji ve Askerî Güç, Çev. Fatih Çalışır, Timaş Yay., İstanbul 2012.

Ahmed Cevad, Tarih-i Askeri-i Osmani, Cild-i evvel, İstanbul 1299.

Ahmed Refik, "Devşirme Usulü, Acemi Oğlanlar", Dârülfünûn Edebiyat Fakültesi Mecmuası, C V, S. 1-2, Haziran 1926, İstanbul Milli Matbaa, 1927, s. 1-14.

Akdağ, Mustafa, "Yeniçeri Ocak Nizamının Bozuluşu”, AÜDTCF Dergisi, C V, Ankara 1947, s. 291-303.

Akgündüz, Ahmet, Osmanh Kanunnâmeleri ve Hukukî Tahlilleri, 9/I. Kitap, I. Ahmed Devri Kanunnâmeleri, 9/II. Kitap, II. Osman Devri Kanunnâmeleri, Osmanlı Araştırmaları Vakfi Yay., İstanbul 1996.

Asşık Paşaoğlu Tarihi, Haz. Atsız, MEB Yay., İstanbul 1992.

Beydilli, Kemal, "Yeniçeri”, DİA, C 43, İstanbul 2013, s. 450-462.

Bir Yeniçerinin Hatıratı, Ģev. Ve Yay. Haz. Kemal Beydilli, Tatav Yay., İstanbul 2003.

Busbecq, Ogier Ghislain de, Türk Mektuplar, Doğan Kitap, İstanbul 2005.

Çelik, Yüksel, "II. Mahmud Devrinde İdari-Askeri Bir Üs: Rami Kışlası", Osmanl Araștırmalar / The Fournal of Ottoman Studies, LII, 2018, s. 227-266.

Eyyubî Efendi Kânûnnâmesi Tahlil ve Metin, Yay. Haz. Abdülkadir Özcan, Eren Yay., İstanbul 1994.

Fatih Sultan Mehmed, Kanunname-i Al-i Osman (Tahlil-Karşılaştırmalı Metin), Haz. Abdülkadir Özcan, Kitabevi, İstanbul 2003.

Fodor, Pál, "Bir Nasihat-name Olarak Kavânîn-i Yeniçeriyan”, V. Milletlerarası Türkoloji Kongresi Bildiriler, 23-28 Eylül 1985, C 1, İstanbul 1986, s. 217-224.

Goodwin, Godfrey, Yeniçeriler, Çev. Derin Türkömer, Doğan Egmont Yay., İstanbul 2008. 
Halaçoğlu, Yusuf, XIV ve XVII. Yüzynllarda Osmanhlarda Devlet Teşkilatı ve Sosyal Yapı, TTK Yay., Ankara 1995.

Hezarfen Hüseyin Efendi, Telhîsüll-Beyân fỉ Kavâninn-i Âl-i Osmân, Haz. Sevim İlgürel, TTK Yay., Ankara 1998.

İlgürel, Mücteba, "Yeniçeriler", IA, C 13, MEB Yay., İstanbul 1986, s. 385-395.

İnalcık, Halil, "Military and Fiscal Transformation in the Ottoman Empire, 16001700", Archivum Ottomanicum, VI, 1980, s. 283-337.

İpşirli, Mehmet, "Osmanlı Devlet Teşkilatına Dair Bir Eser: Kavânîn-i Osmânî ve Râbıta-i Âsitâne", İ.Ü. Edebiyat Fakültesi, Tarih Enstitiusï Dergisi, XIV, 1994, s. 9-35.

İşbilir, Ömer, XVII. Yüzynl Başlarnnda Şark Seferlerinin İâse, İkmâl ve Lojistik Meseleleri, İ.Ü. Sosyal Bilimler Enstitüsü, Basılmamış Doktora Tezi, İstanbul 1996.

Kafadar, Cemal, "Yeniçeriler", Dünden Bugüne İstanbul Ansiklopedisi, C 7, Tarih Vakfi Yay., İstanbul 1994, s. 472-476.

Káldy-Nagy, Gyula, "The First Centuries of The Ottoman Military Organization", Acta Orientalia, Tomus. XXXI, Budapest 1977, pp. 147-183.

Kanuni Devrinde Yeniçeri Ocağına Dair Bazı Merasim, İÜ Nadir Eserler Kütüphanesi Türkçe Yazmalar Koleksiyonu, No: 3293.

Kavanin-i Yeniçeriyan (Yeniçeri Kanunlar), Yay. Haz. Tayfun Toroser, İş Bankası Yay., İstanbul 2011.

Kaytaz, Fatma, "Osmanlı Askerî Teşkilatı Hakkında Bilinmeyen Bir Eser "Yeniçeri Ocağına İlişkin Bir Risale" (Değerlendirme Ve Metin)", Tarih Dergisi, Sayı 57 (2013 / 1), İstanbul 2013, s. 45-68.

Kazıcı, Ziya, Osmanhlarda İhtisab Müessesesi, İstanbul 1987.

Osmanh Devlet Teşkilatına Dair Kaynaklar Kitâb-ı Mïstetâb-Kitâbu Mesâlihi'l-Müslimîn Menâfi'il-Mü'minîn-Hirzü'l-mülûk, Haz. Yaşar Yücel, TTK Yay., Ankara 1988.

Koçi Bey Risalesi, Haz. Yılmaz Kurt, Akçağ Yay., Ankara 1998.

Koyuncu, Aşkın, "Kavânîn-i Yeniçeriyân ve Bosnalı Müslüman Çocuklarının Devşirilmesi Meselesinin Tenkidi”, Uluslararası Balkan Tarihi ve Kültürü Sempozyumu, 6-8 Ekim 2016, Çanakkale, Bildiriler, C I. Ed. Aşkın Koyuncu, Çanakkale: 
Çanakkale Onsekiz Mart Üniversitesi Balkan ve Ege Uygulama ve Araştırma Merkezi, 2017, s. 193-233.

Küçükyalçın, Erdal, Turna’nın Kalbi Yeniçeri Yoldaşlĭ̆ı ve Bektaşilik, Boğaziçi Ün. Yay., İstanbul 2010.

Mehmed Süreyya, Sicill-i Osmanî, G I, Yay. Haz. Nuri Akbayar, Eski Yazıdan Aktaran: Seyit Ali Kahraman, Tarih Vakfi Yurt Yay., İstanbul 1996.

Murphey, Rhoads, Osmanl`'da Ordu ve Savaş 1500-1700, Çev. M. Tanju Akad, Homer Kitabevi, İstanbul 2007.

Mustafa Nuri Paşa, Netayicü'l-Vukuat, C I-II, Sad. Neşet Çăgatay, TTK Yay., Ankara 1992.

Nicolas de Nicolay, Muhteşem Süleyman’n İmparatorluğunda, Ed. Marie-Christine Gomez-Geraud, Stefanos Yerasimos, Çev. Şirin Tekeli-Menekşe Tokyay, Kitap Yay., İstanbul 2014.

Oruç Bey, Osmanl Tarihi (1288-1502) Uç Beylïğinden Dünya Devletine, Sad. Necdet Öztürk, Çamlıca Yay., İstanbul 2009.

Osmanl Sadrazamlan Hadikatü'l-Vüzerâ ve Zeylleri 3, Haz. Mehmet Arslan, Kitabevi Yay., İstanbul 2013.

Öz, Mehmet, Kanun-ı Kadimin Peşinde Osmanlı'da Çözülme ve Gelenekçi Yorumcular, 7. Bsk., Dergâh Yay., İstanbul 2017.

Özbek, Özgül, "Yeniçeri Kanunları Kitabı: Kavânîn-i Yeniçeriyân”, Turkish Studies, Volume 13/5, Winter 2018, pp. 375-388.

Özcan, Abdülkadir, "Etmeydanı”, DİA, C 13, s. 497-498.

Özcan, Abdülkadir, "Osmanlı Askeri Teşkilatı", Osmanh Devleti ve Medeniveti Tarihi, Ed. Ekmeleddin İhsanoğlu, C I, IRCICA, İstanbul 1994, s. 337-371.

Petrosyan, Irina Ye., "Osmanl Devleti'nin Kuruluşu ve Yeniçerilerin Kökeni”, Türkler, C 10, Yeni Türkiye Yay., s. 129-135.

Petrosyan, Irina Ye., “Osmanlı İmparatorluğu’nda Askeri Reformlar Konusunda İlk Girişim: XVI. Yüzyılın Sonu İle XVII. Yüzyılın Başında Yeniçeri Ocağı”, Osmanl, C 6, Ankara 1999, s. 673-683.

Petrosyan, Irina Ye., Mebde'-i Kanûn-ı Yeniçeri Ocă̆ı Tarihi, Moskova 1987. 
Pul, Ayşe, Yeniçeri Ocă̆ını 68. Ortası Turnacıbaşlık, Gece Kitaplığı Yay., Ankara 2016.

Reed, Howard A., "Ottoman Reform and Janissaries: The Eşkenci Lâyihas of 1826", Türkiye'nin Sosyal ve Ekonomik Tarihi (1071-1920), Ed. Osman Okyar-Halil İnalcık, Ankara 1980, s. 193-198.

Sakaoğlu, Necdet, "Eski Odalar", Dünden Bugüne İstanbul Ansiklopedisi, G III, s. 203204.

Sakaoğlu, Necdet, "Yeni Odalar", Dünden Bugüne İstanbul Ansiklopedisi, C VII, s. 467-468.

Sakin, Orhan, Yeniçeri Ocağı Tarihi ve Yasalar, Doğu Kütüphanesi Yay., İstanbul 2011.

Schimmel, Annemarie, Sayılarn Gizemi, Çev. Mustafa Küpüşoğlu, Kabalcı Yay., İstanbul 2000.

Selânikî Mustafa Efendi, Tarih-i Selânikî (971-1003/1563-1595), C I-II, Haz. Mehmet İpşirli, TTK Yay., Ankara 1999.

Sertoğlu, Midhat, Osmanl Tarih Lûgatı, Enderun Kitabevi, İstanbul 1986.

Sunar, Mehmet Mert, "Ulufe", DIA, G 42, İstanbul 2012, s. 124-126.

Sunar, Mehmet Mert, "XVIII. Yüzyıl ve XIX. Yüzyıl Başları Yeniçeri Kışlaları Üzerine Bir Değerlendirme", Yeni Bir Askerî Tarih Özlemi Savas, Teknoloji ve Deneysel Çalışmalar, Yay. Haz. Kahraman Şakul, Tarih Vakfi Yurt Yay., İstanbul, 2013, s. 252-276.

Sunar, Mehmet Mert, “İstanbul'da Yeniçeri Mekânları: Eski ve Yeni Odalar”, $A n$ tikçağdan XXI. Yüzylla Büyük İstanbul Tarihi, C II, İstanbul, 2015, s. 191-197.

Topçular Kâtibi Abdülkadir, Kadrî Efendi Tarihi, C I, Haz. Ziya Yılmazer, TTK Yay., Ankara 2003.

Uzunçarşılı, İsmail Hakkı, Osmanh Devleti Teşkilatından Kapukulu Ocaklam, C I, TTK Yay., Ankara 1988.

Uzunçarşılı, İsmail Hakkı, Osmanı Tarihi, C II, TTK Yay., Ankara 1983.

Üçok, Coşkun-MUMCU, Ahmet, Türk Hukuk Tarihi, Savaş Yay., Ankara 1991.

Ünver, A. Süheyl, "Yeniçeri Kışlaları”, Belleten, G XL, S. 160, Ankara 1976, s. 589-594. 
Yediyıldız, Bahaeddin, "Osmanlı Toplumu", Osmanl Devleti ve Medeniyeti Tarihi, Yay. Ekmeleddin İhsanoğlu, C I, IRCICA (İslâm Tarih, Sanat ve Kültür Araştırma Merkezi) Yay., İstanbul 1994-1998, s. 441-650. 


\section{EKLER}

\section{TTK Nüshası Orijinal Metin}

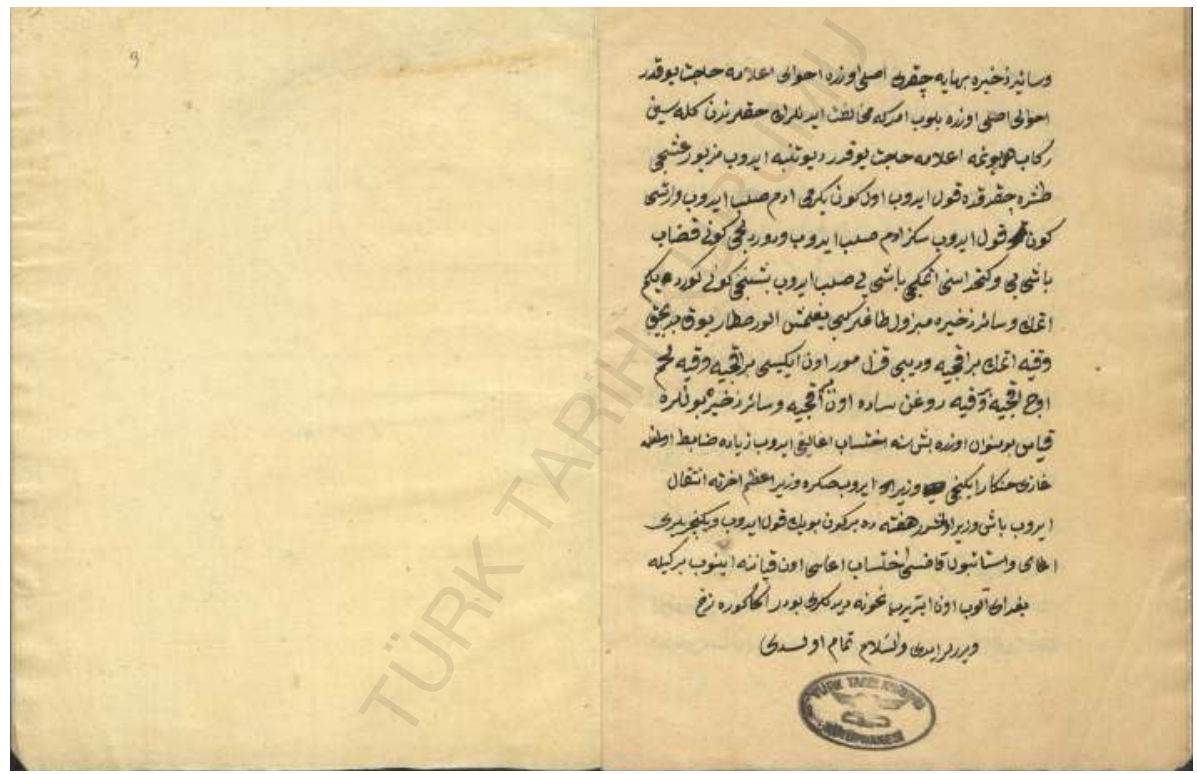

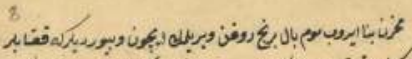

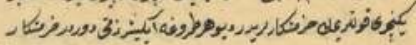

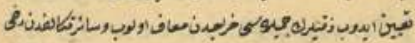

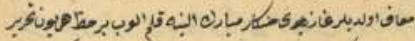

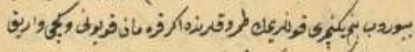

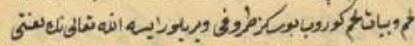

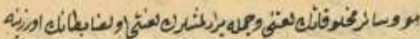

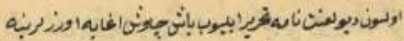

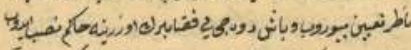

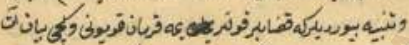

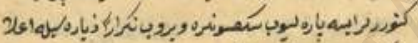

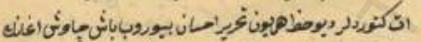

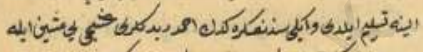

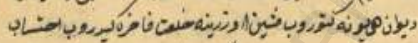

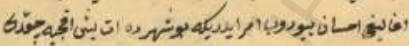

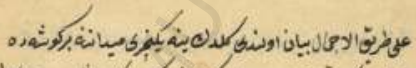

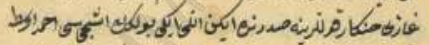

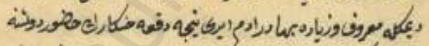

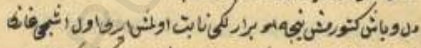

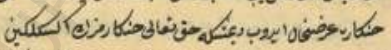

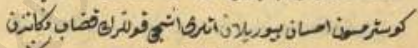

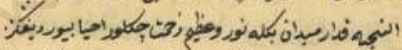

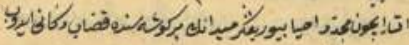

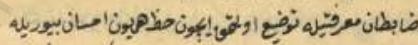

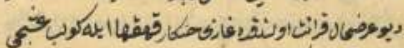

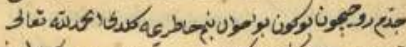

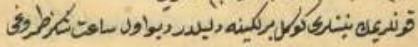

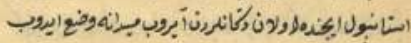

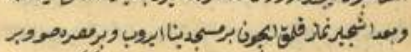

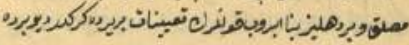

خرن 


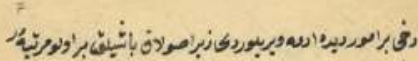

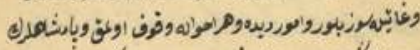

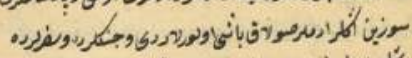

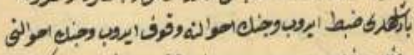

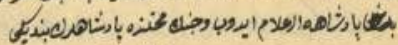

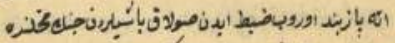

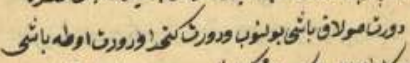

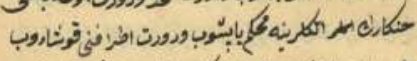

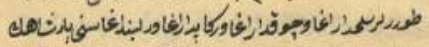

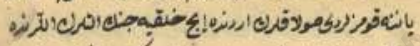

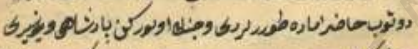

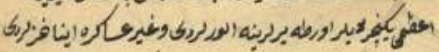

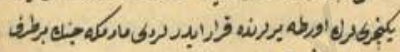

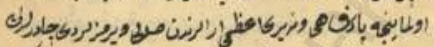

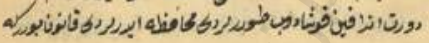

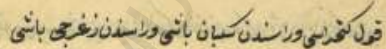

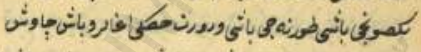

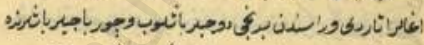

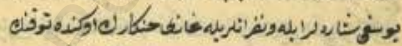

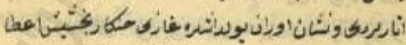

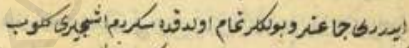

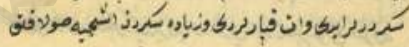

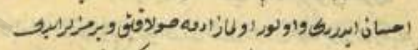

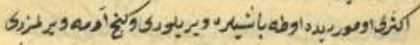

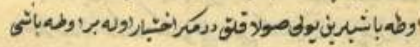

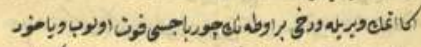

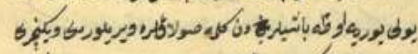

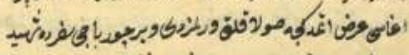

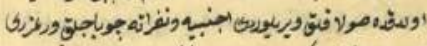

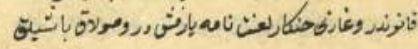
(8)

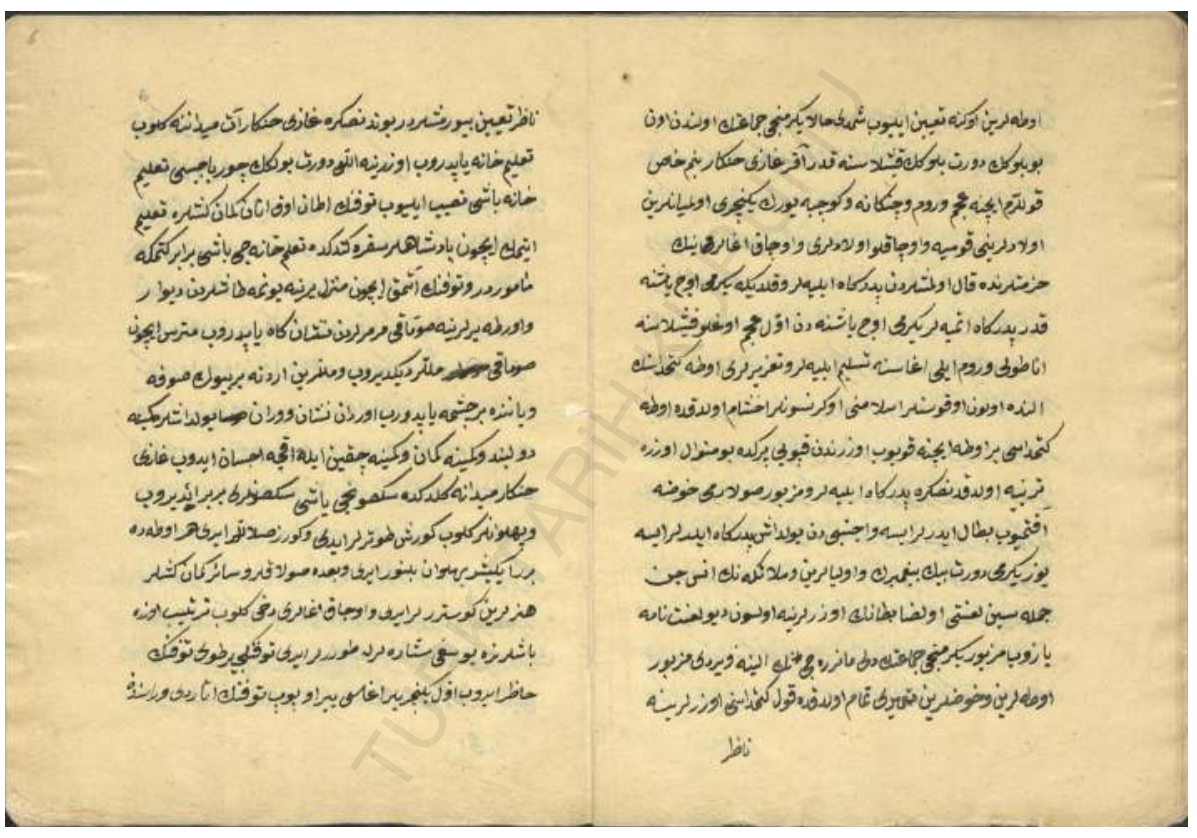

Belleten, Aralık 2020, Cilt: 84/Sayı: 301; 983-1044 


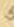

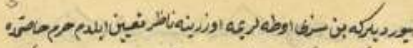

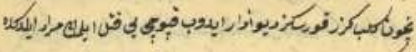

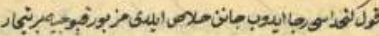

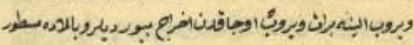

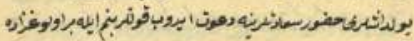

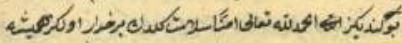

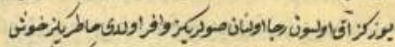

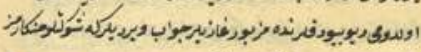

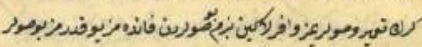

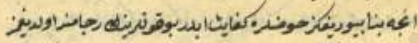

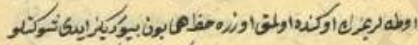

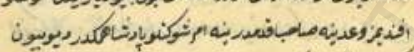

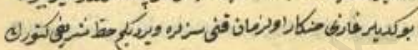

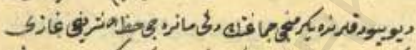

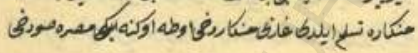

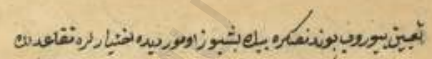

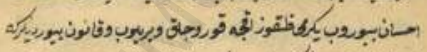

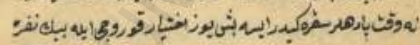

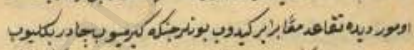

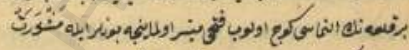

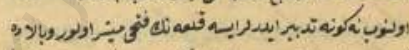

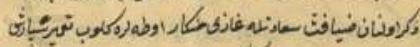

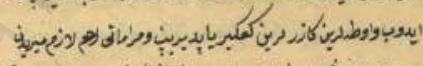

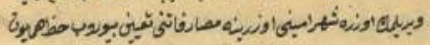

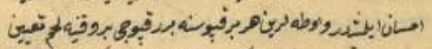

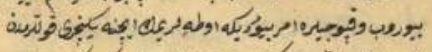

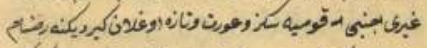

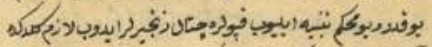

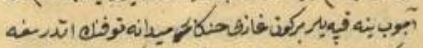

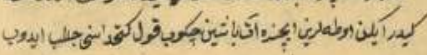

2..

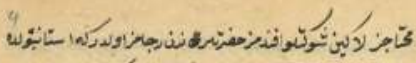

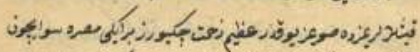

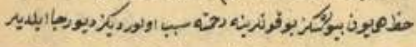

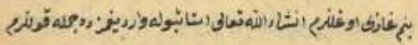

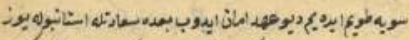

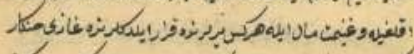

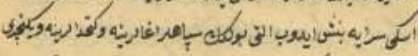

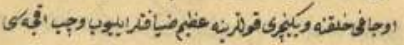

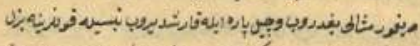

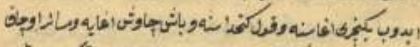

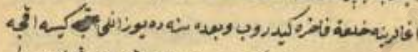

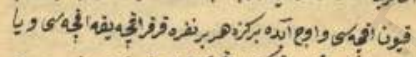

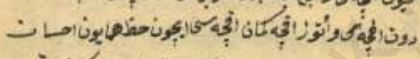

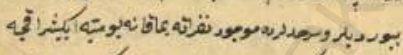

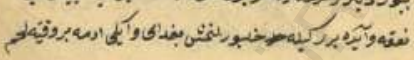

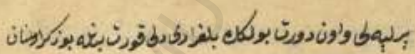

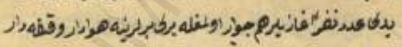

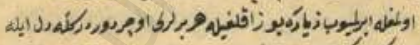

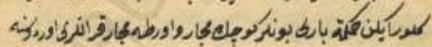

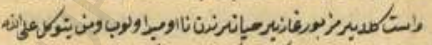

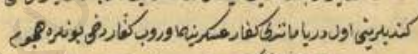

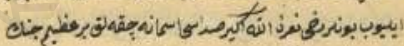

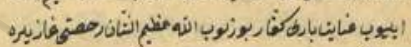

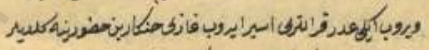

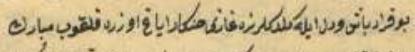

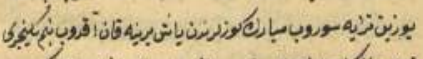

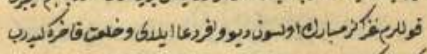

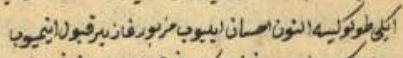

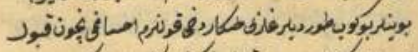

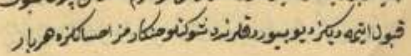
3تاجم 


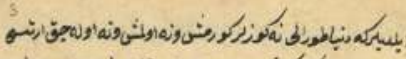

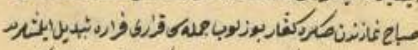

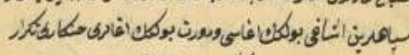

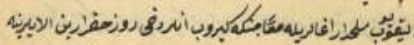

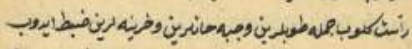

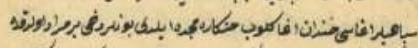

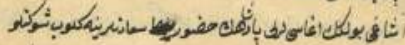

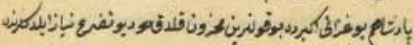

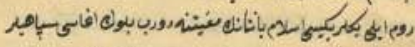

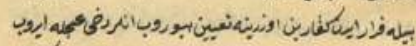

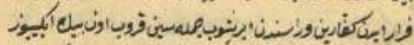

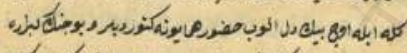

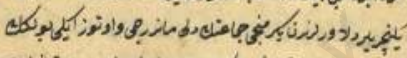

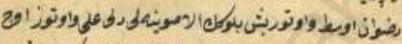

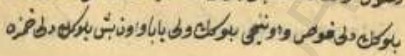

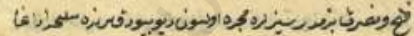

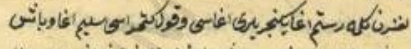

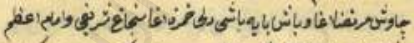

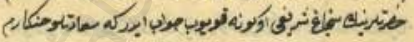

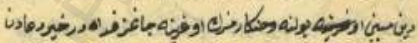

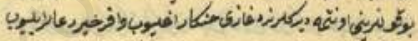

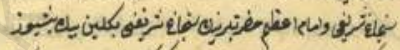

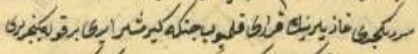

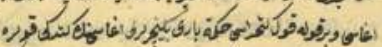

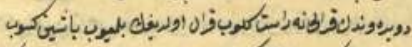

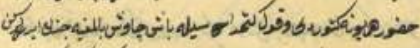

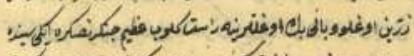

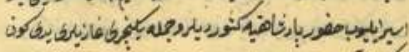

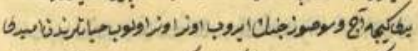

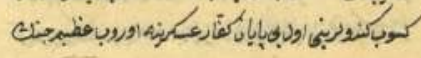
ابديبرك

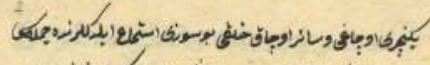

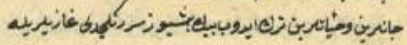

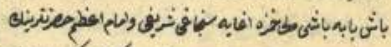

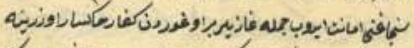

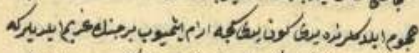

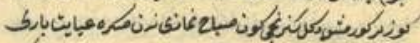

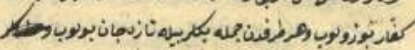

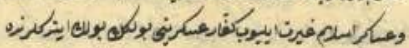

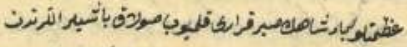

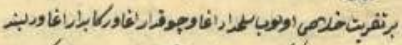

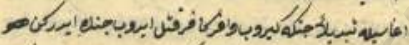

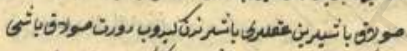

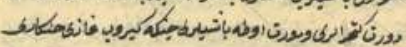

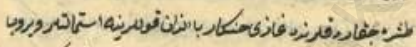

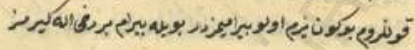

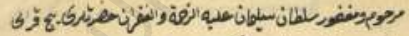

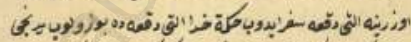

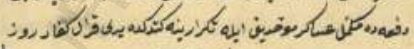

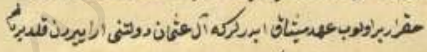

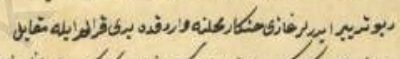

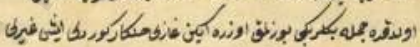

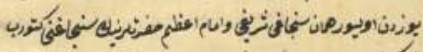

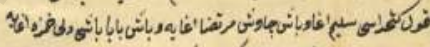

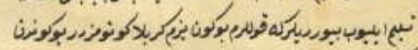

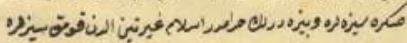

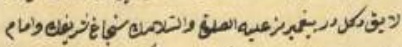

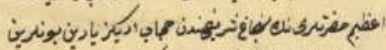

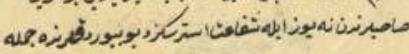
كبجن 